\title{
CERCETĂRI ARHEOLOGICE SISTEMATICE ÎN CUPRINSUL SITULUI HALLSTATTIAN TĂRTARIA-PODU TĂRTĂRIEI VEST. RAPORT PRELIMINAR AL CAMPANIILOR 2016-2017
}

\author{
CORINA BORȘ, LUCIANA RUMEGA-IRIMUȘ, VLAD RUMEGA-IRIMUȘ
}

\section{SCHEDULED ARCHAEOLOGICAL EXCAVATIONS ON THE HALLSTATT AGE SITE FROM TĂRTARIA-PODU TĂRTĂRIEI VEST. PRELIMINARY REPORT OF THE 2016-2017 CAMPAIGNS}

\begin{abstract}
The discovery of the prehistoric site from Tărtăria-Podu Tărtăriei vest (Alba County) was made in 2012 by large-scale preventive archaeological field investigations occasioned by the construction of the Al motorway along the Mureș river valley. The site is located north to Tărtăria village (Săliștea commune), on a plateau situated on the upper left terrace of the mentioned valley. In 2012, throughout an open area archaeological excavation was completely investigated an area of about 2 hectares (on the southern and eastern limits of the site), where significant archaeological features and vestiges were discovered, providing major new data and finds for Middle Hallstatt period - the Basarabi pottery style. The most important ones are two ditches marking the southern and eastern limits of the site, two bronze hoards (comprising over 400 bronze and iron objects, dated to the middle period of the First Iron Age / the Middle Hallstatt period - the Bâlvănești-Vinț series of bronze hoards, $8^{\text {th }} \mathrm{c} . \mathrm{BC}$ ) and a collective grave. Since 2016 was initiated a scheduled archaeological project, aiming both field excavations and geophysics surveys. As a result, a large-scale magnetic survey and aerial photography were made for documenting the setting of the prehistoric site. Considering the evidence provided by the 2014 and the 2016 geophysics surveys, was set an excavation perimeter in the northern part of the site, by opening two main trenches. In 2017, a third main trench was added to these two ones. Six new archaeological features (pits) were uncovered (all assigned based on the inventory to the Middle Hallstatt period - the Basarabi culture), and was finalised the field investigation for other two, which were identified in 2016. The finds comprise a considerable amount of pottery (including entire vessels with characteristic Basarabi style decoration), as well as a portable hearth, a fragmentary zoomorphic figurine, a miniature stone axe reused as pendant, and a series of metal object - two iron knifes, an iron blade and a bronze hair-pin with the ending in " 8 " shape.Also were taken a series of aerial images, and in late autumn 2017 was made a preliminary geomagnetic prospection on the western part of the site. Considering all the data recorded up to now and the preliminary analysis of the very rich archaeological finds from Tărtăria-PoduTărtăriei vest, one can consider this site as a very important one for the study of middle period of the First Iron Age in Transylvania and neighbouring areas. Although preliminary, the results of the field researches of 2017 made in here emphasize once again the site's particular features and the necessity for its longterm field research and protection.
\end{abstract}

KEYWORDS: middle period of the First Iron Age (middle Hallstatt), Basarabi pottery style.

CUVINTE CHEIE: perioada mijlocie a primei epoci a fierului (Hallstatt mijlociu), stilul ceramic Basarabi.

\section{SCURTĂ INTRODUCERE}

Această importantă stațiune arheologică preistorică, descoperită în urmă cu 5 ani, este situată în județul Alba, comuna Săliștea, satul Tărtăria, în zona situată la nord-vest de acesta. De vreme ce a fost necesară identificarea distinctă a acestui sit datând din perioada mijlocie a primei epoci a fierului (perioada culturii Basarabi) de bine-cunoscută stațiune neolitică de la Tărtăria-Gura Luncii, apelând la toponimia locală și hărțile de referință acest de-al doilea important sit aflat în cuprinsul teritoriului administrativ al satului Tărtăria a fost denumit Tărtăria-Podu Tărtăriei vest. Situl hallstattian, descoperit în anul 2012 cu prilejul cercetărilor arheologice preventive determinate de construirea autostrăzii Orăștie-Sibiu, se află situat pe partea stângă a văii mijlocii a Mureșului, la nord de autostrada A1 și la sud de DN7, chiar la intrarea în satul sus-menționat. Lucrările agricole intense care se desfășoară de câteva decenii în această zonă afectează în mare măsură suprafața sitului, așa cum se poate observa atât pe imagini aeriene și hărți de arhivă, dar și direct, cu prilejul cercetărilor preventive din anii 2011-2012, respectiv a celor sistematice din campaniile 2016-2017. Prin cercetările arheologice preventive din anul primăvara și vara anului 2012, desfășurate în porțiunile sudică și estică ale sitului (PI. I-III), a fost confirmată existența aici a unui important habitat preistoric, unde se păstrează importante vestigii încadrabile în perioada mijlocie a primei epoci a fierului (Hallstatt-ului 
mijlociu / perioada culturii Basarabi $)^{1}$. Campaniile de cercetare arheologică sistematică din perioada 2016-2017 s-au concentrat în partea nordică a sitului ${ }^{2}$, confirmând suprafața amplă pe care o ocupă această stațiune preistorică pe prima terasă a râului Mureș $(\mathbf{P I}$. XVI).

Trebuie amintit și faptul că acesta este unul din cazurile aparte ale arheologiei din România ultimelor două decenii, dată fiind oportunitatea și posibilitatea de a continua cercetarea arheologică preventivă de amploare din anul 2012 (într-un sit anterior necunoscut) prin extinderea şi aprofundarea sa în cadrul unui program multianual de săpătură arheologică sistematică și investigații pluridisciplinare conexe.

\section{NOI DESCOPERIRI ARHEOLOGICE ÎN RAZA ADMINISTRATIVĂ A LOCALITĂȚII TĂRTĂRIA (PI. IV)}

În ultimii 5 ani, au fost efectuate în limita administrativă a localităţii Tărtăria o serie de noi descoperiri, care împreună cu cele cunoscute anterior reconfirmă potențialul arheologic deosebit al acestui areal. Astfel, la est de situl hallstattian identificat și cercetat în anii 2011-2012, în partea estică a platoului numit Podu Tărtăriei, au fost descoperite în anul 2011 - în contextul desfășurării lucrărilor de diagnostic arheologic pe traseul autostrăzii A1: Orăștie-Sibiu, lotul 1 - urme ale unei locuiri medievale timpurii (sec. XI-XIII) ${ }^{3}$. În perioada 2014-2015, spre nord, către lunca Mureșului, în zona situată la Nord-Est și Est de bine-cunoscuta stațiune neo-eneolitică (de tip tell) de la Tărtăria-Gura Luncii, dar și propriu-zis în partea sudică a acesteia, au fost efectuate cercetări arheologice preventive - ocazionate de modernizarea traseului căii ferate Brașov-Simeria, componenta A, Coridorul IV PanEuropean, tronsonul Vințu de Jos-Simeria - care au prilejuit noi descoperiri ${ }^{4}$ (unele in situ, altele în poziție secundară), datând din perioada culturilor Starčevo-Criș, Vinča - fazaA3, Petrești, Coțofeni, Noua, dar și prima (cultura Basarabi) și a doua epocă a fierului, cât și din epoca romană, respectiv perioada medievală - secolul al XIII-lea). Un alt punct de interes arheologic din acest areal, anume zona terasei denumite Pietroșița, aşa-numitul sit 10 (conform numerotării stabilite de autorii cercetărilor preventive din campania 2014) a fost - de asemenea - cercetat prin săpături arheologice preventive prilejuite de aceleași lucrări de infrastructură pentru calea ferată5 ${ }^{5}$; aici au fost descoperite vestigiile unei așezări medievale de dimensiuni reduse, datând din secolul al XII-lea, dar și vestigii preistorice, atribuite culturilor Criș și Coțofeni ${ }^{6}$, precum și perioadei Latène (etapa $\left.\mathrm{C} 1\right)^{7}$. Alte descoperiri datând din perioada culturilor Coțofeni (faza I) și Noua au fost realizate în așa-numitul sit 9, delimitat și cercetat tot în anul 2014, cu ocazia derulării acelorași lucrări de infrastructură pentru calea ferată în zona haltei CFR Tărtăria ${ }^{8}$. Alte vestigii atribuite culturii Vinča - fazaA3 au fost descoperite în zona situată la Sud-Vest de stațiunea neo-eneolitică de la Tărtăria-Gura Luncii, cu prilejul cercetării preventivă a acestei porțiuni, localizată imediat la Nord de fostul traseu (între timp modernizat și extins) al căii ferate ${ }^{9}$.

Date fiind toate aceste noi descoperiri arheologice trebuie remarcat că este regretabil faptul că nu au fost publicate - fie și preliminar - toate noile informații de interes arheologic prilejuite de lucrările de infrastructură realizate pentru modernizarea căii ferate amintite mai sus. Judecând după datele parțiale publicate până în prezent pentru aceste cercetări arheologice preventive din anii 2014-

\footnotetext{
${ }^{1}$ Borș et alii 2014, 9-102.

2 Având în vedere că este vorba de un sit arheologic unitar, s-a optat pentru numerotarea în continuare a unităților de săpătură și complexelor în raport cu cele din cercetarea arheologică preventivă din anul 2012. Astfel, în 2016 au fost deschise secțiunile magistrale S032 și S033, orientate aproximativ N - S în partea nordică a sitului, cu martor intermediar de $1 \mathrm{~m}$. Pentru $\mathrm{S}_{032}$ au fost deschise 5 casete $(\mathrm{A}-\mathrm{E})[4 \mathrm{x} 4 \mathrm{~m}$ cu martor intermediar de $1 \mathrm{~m}$, aceștia fiind ulterior demontați]. Pentru $\mathrm{S}_{033}$ au fost deschise 2 casete $(\mathrm{A}-\mathrm{B})[4 \mathrm{x} 4 \mathrm{~m}$ cu martor intermediar de $1 \mathrm{~m}$, aceștia fiind ulterior demontați]. Ulterior, în campania 2017 a fost deschisă secțiunea magistrală S S034, situată la Vest de S S 32 cercetată în campania precedentă, ambele orientate aproximativ Nord-Sud în partea nordică a sitului, cu martor intermediar de $1 \mathrm{~m}$. În secțiunea $\mathrm{S}_{034}$ au fost deschise 4 casete (A-D), având dimensiuni de $4 \times 4 \mathrm{~m}$ cu martori intermediari de $1 \mathrm{~m}$, de asemenea aceștia fiind ulterior demontați. A continuat și cercetarea secțiunii $\mathrm{S}_{033}$, fiind deschise alte 3 noi casete (C-E), având dimensiuni de $4 \times 4 \mathrm{~m}$ cu martori intermediari de $1 \mathrm{~m}$, și aceștia fiind ulterior demontați.

${ }^{3}$ Dumitrașcu, Ene, Streinu 2015, 41-63.

${ }^{4}$ Luca 2016, p. 20, 27.

${ }^{5}$ Craiovan, Micle 2015, 497.

${ }^{6}$ Rogozea, Micle, Dincă 2017, 239.

${ }^{7}$ Ferencz, Roman 2015, 156-164.

${ }^{8}$ Rogozea, Micle, Dincă 2017, 233-235.

${ }^{9}$ Rogozea 2016, 121-123.
} 
$2015^{10}$ este foarte clar faptul că porțiunea dintre prima terasă a Mureșului și cea de-a doua, traversată de traseul DN 7 și al căii ferate, chiar dacă puternic afectată de lucrări de infrastructură începând cu jumătatea secolului al XIX-lea, are un important potențial arheologic - dată fiind proximitatea cu bine-cunoscutul sit de la Tărtăria-Gura Luncii și recent identificatul sit Tărtăria-Podu Tărtăriei vest. Mai mult decât atât, este neclar de ce au fost autorizate și alte noi lucrări de amenajare (un iaz către Nord-Est și o stație de procesare a deșeurilor imediat la Vest de situl Tărtăria-Gura Luncii, foarte probabil chiar în zona de protecție a acestei stațiuni arheologice clasate în Lista Monumentelor Istorice ca monument de categorie A) în porțiunea de la nord de situl hallstattian Tărtăria (PI. V), anume în zona traversată de traseul DN 7 și calea ferată, iar rezultatele cercetărilor arheologice preventive care vor fi fost efectuate aici nu au fost nici măcar semnalate ${ }^{11}$.

SCURTE CONSIDERAȚII DESPRE PRIMELE DOUĂ CAMPANII DE CERCETĂRI ARHEOLOGICE SISTEMATICE ÎN CUPRINSUL SITULUI HALLSTATTIAN TĂRTĂRIA-PODU TĂRTĂRIEI

\section{SCOPUL CERCETĂRII SISTEMATICE}

Scopul inițial al cercetărilor arheologice din zona Tărtăria-Podu Tărtăriei vest a fost determinat în anul 2012 de lucrările de construire ale autostrăzii A1: Orăștie-Sibiu / lot 1: OrăștieSebeș, aşadar o cercetarea arheologică preventivă subsumată conceptului de salvgardare prin înregistrare, corelat cu parcurgerea procedurii administrative de descărcare de sarcină arheologică în conformitate cu legislația națională de referință. Astfel, la finalul cercetărilor arheologice preventive de acum 5 ani a fost evident faptul că în zona Tărtăria-Podu Tărtăriei vest se afla un important sit hallstattian (necunoscut anterior), care a fost numai parțial afectat, pe laturile sale sudică și estică, de lucrările de infrastructură menţionate și că se impunea continuarea cercetării în acest areal, în special în perimetrul cuprins între: traseul DN 7 - către Nord, traseul A1 - către Sud, traseul DC 705E / Valea Rea - către Est și Valea Ciorii - către Vest.

Pornind de la aceste premise, în anul 2014 a fost efectuată o primă serie de investigații nonintrusive în colaborare cu specialiști din cadrul Universității „Alexandru Ioan Cuza” din Iași Platforma de Cercetare Interdisciplinară ARHEOINVEST, extinse apoi prin prospectările din 20162017 (Pl. VI-VII, XI, XIII, XX).

Din anul 2016, programul multianual de cercetare arheologică sistematică pluridisciplinară (pentru o perioadă de 5 ani), aprobat de Comisia Națională de Arheologie, are în vedere următoarele obiective:

- $\quad$ stabilirea limitelor sitului;

- $\quad$ stabilirea modului său de delimitare (fortificare ?) în perioada Hallstatt-ului mijlociu;

- $\quad$ stabilirea funcționalității sitului (așezare fortificată versus arie de depunere) în perioada Hallstatt-ului mijlociu;

- clarificarea necesităţii de fortificare în perioada evului mediu timpuriu, în zona estică a sitului;

- $\quad$ studierea și înțelegerea modalităţii încadrării în peisaj a sitului în perioada primei epoci a fierului (c. Basarabi);

- $\quad$ aprofundarea cunoașterii cu privire la în perioada Hallstatt-ului mijlociu (c. Basarabi);

- îmbogățirea colecțiilor muzeale prin cercetare de specialitate.

\footnotetext{
${ }^{10}$ Vezi supra n. 4-9.

${ }^{11}$ Din datele publice existente în sistemul ACERA (http://arh.cimec.ro/) rezultă că: pentru campania anului 2014 nu este înregistrată nici o lucrare de arheologie preventivă în această zonă, deși în literatura de specialitate există asemenea semnalări; pentru cea din anul 2015 figurează numai cercetările arheologice preventive în legătură cu modernizarea tronsonului de cale ferată situat imediat la Sud de situl Tărtăria-Gura Luncii (însă numai pentru km 429+960 - km 430+160); pentru campania din anul 2016 figurează numai lucrări de supraveghere arheologică în zona siturilor 11 și 12 , delimitate în legătură cu aceleaşi lucrări de infrastructură din proximitatea stațiunii neo-eneolitice amintite; pentru campania anului 2017 sunt înregistrate numai lucrări de supraveghere în zona sus-numitului sit, fără alte precizări. Așadar, datele sunt neclare atât pentru lucrările de arheologie preventivă ocazionate de modernizarea căii ferate din perioada 20142015, conform semnalărilor din literatura de specialitate citate mai sus, dar și pentru cele privind construcția iazului și a stației de procesare a deșeurilor, elemente clar vizibile pe imaginile aeriene realizate din dronă în toamna anului 2016, în contextul începerii cercetărilor arheologice sistematice în cadrul sitului hallstattian Tărtăria-Podu Tărtăriei vest și al demersurilor pentru clasarea acestuia în Lista Monumentelor Istorice.
} 


\section{CONSIDERAȚII GENERALE}

În cele două campanii de cercetare arheologică sistematică în cuprinsul acestui sit, dată fiind suprafața apreciabilă a acestuia (de peste 15 ha), dar și resursele - umane și materiale - care au putut fi utilizate pentru cercetarea sa a fost necesară combinarea unor metode non-intrusive (aerofotografii și noi prospectări geomagnetice, pentru moment doar parțiale, în zona vestică a sitului) cu cele intrusive (săpătură arheologică / sondare / periegheză). Într-o primă etapă a cercetării, pornind de la rezultatele investigatiilor geofizice din 2014 am stabilit investigarea unui perimetru de peste $300 \mathrm{~m}^{2}$, în partea nordică a sitului ${ }^{12}$. Săpătura a fost proiectată într-un sistem de secțiuni magistrale, divizate în casete de $4 \times 4 \mathrm{~m}$, cu martor intermediar de $1 \mathrm{~m}$, deopotrivă transversal și longitudinal, pentru stabilirea limitelor sitului și completarea stratigrafiei sale generale. În campaniile 2016-2017, utilizând rezultatele preliminare ale prospecțiunilor magnetometrice din anul 2014 și apoi cele ale prospectărilor geomagnetice și rezultatele cercetărilor arheologice din campania 2016, au fost deschise trei secțiuni magistrale în perimetrul stabilit din zona nordică a sitului. Ulterior, ținând cont de distribuția și caracteristicile contextelor și complexelor identificate preliminar în cadrul secțiunilor magistrale $\left(\mathrm{S}_{032}, \mathrm{~S}_{033}\right.$ și $\left.\mathrm{S}_{034}\right)$ a fost dezvoltată o săpătură în suprafață, utilizând un sistem de casete și carouri care permite realizarea de observații stratigrafice în detaliu, înregistrarea și prelevarea cât mai acurată a datelor și materialelor arheologice. Per ansamblu, în campaniile 2016-2017, în acest prim perimetru din zona nordică a sitului a fost efectuată o cercetare exhaustivă totalizând în suprafață de $335 \mathrm{~m}^{2}$ (PI. XI, XII, XVI-XVIII).

În ceea ce privește profilele secțiunilor magistrale acestea au fost curățate și îndreptate cât mai precis posibil prin răzuială manuală cu cazmaua, iar înregistrarea datelor astfel observate a fost realizată deopotrivă prin fotografiere și desen arheologic. După decapare - îndepărtarea stratului vegetal prin săpătură efectuată manual sub strictă supraveghere arheologică - s-a urmărit delimitarea stratului de cultură și a complexelor prin efectuarea unor răzuieli succesive. După identificare și conturare complexelor și contextelor acestea au primit siglă de complex ${ }^{13}$, fiind descrise preliminar. Complexele sunt mai întâi fotografiate la conturare, apoi desenate la scara 1/20, cu excepția unor detalii precum dispunerea artefactelor (sau ecofactelor) în umplutura unor gropi, care sunt înregistrate la scara $1 / 10$ (inclusiv prin fotografie verticală georeferențiată). Localizarea complexelor este înregistrată cu stația totală, datele fiind ulterior integrate în planul general și proiectul GIS de către un arheolog special desemnat, membru în echipa de cercetare. În etapa ulterioară a săpăturii se procedează la secționarea complexelor. S-a încercat, pe cât posibil, ca gropile să fie secționate de-a lungul diametrului maxim; în general, acestea au fost golite pe contur, după înregistrarea prin fotografie (de ansamblu și detaliu) și desen a profilului. Pentru gestionarea eficientă a datelor se utilizează fișe standard pentru unitățile de săpătură (sondaje / secțiuni magistrale / suprafețe / carouri), complexe arheologice și materialul special (vase întregi / întregibile, piese de metal, piatră prelucrată, os etc.).

De asemenea, în ceea ce privește modalitatea de înregistrare a informaţiilor de interes se utilizează metode descriptive uzuale în arheologie, respectiv texte, desene - grund și profil, fotografii, măsurători altimetrice și topografice etc. Sunt realizate planuri și profile (generale şi de detaliu), cât și fotografii în format digital pentru diferitele stadii de cercetare ale unităţilor de săpătură și complexelor (conturare / secționare / finalizare).

Sunt în curs de realizare o serie de datări noi datări radiocarbon pe baza probelor osteologice și de cărbune prelevate din diverse contexte în această campanie. De asemenea, au fost inițiate studii de bioarheologie şi arheozoologie (PI. XLVII).

DETALII PRIVIND ÎNREGISTRAREA MATERIALULUI ARHEOLOGIC ȘI COMPLETAREA BAZEI DE DATE A ȘANTIERULUI

Pornind de la metodologia de lucru adoptată pentru campania de săpături arheologice preventive din campania 2012, cu prilejul primelor două campanii de săpături arheologice cu caracter programat a fost realizată o înregistrare cu cât mai mare acuratețe și coerență a diverselor categorii de date, respectând standardele uzuale pentru domeniul arheologiei. Dată fiind experiența din anii trecuți,

\footnotetext{
12 Borș et alii 2017, 139-140.

${ }^{13}$ Prima siglă de complex utilizată în campania 2016 este Cx 259, iar în campania 2017 Cx 269, în continuarea sistemului de numerotare utilizat în campania de cercetare arheologică preventivă din 2012.
} 
dar și cantitatea de material arheologic descoperită în campania preventivă din anul 2012, s-a dovedit necesară utilizarea unor fișe standard de evidență, dar și a bazelor de date și a numerotării standardizate pentru a păstra evidența variilor tipuri de înregistrări și pentru a facilita schimbul de date în cadrul întregului colectiv de cercetare. Îmbinând metode de înregistrare „clasice” cu cele mai moderne (de ex. măsurători topografice detaliate, imagini din dronă etc.) s-a reuşit ca într-un timp destul de scurt (circa 4 luni) de la finalizarea săpăturii, deopotrivă pentru campania din anul 2016, dar și cea din 2017, să existe o situație clară, atât cantitativă, cât și spațială pentru întreg materialul arheologic prelevat, precum și pentru datele de referință asociate acestuia.

\section{BAZE DE DATE PENTRU EVIDENȚA PRIMARĂ A MATERIALULUI ARHEOLOGIC ȘI TOPOMETRIE}

Continuând în sensul modelului de lucru adoptat din campania 2016, în anul 2017 nu s-au adus modificări în sistemul de înregistrare al materialului arheologic prin bilete ${ }^{14}$. Au fost realizate înregistrări constante în baza de date pentru evidența primară a materialului arheologic. Numerele de ordine (unice pentru fiecare bilet) sunt alocate pentru fiecare campanie în parte. Folosind tabele de evidență în format Excel (din pachetul Microsoft Office), biletele de material completate pe săpătură, au fost înregistrate constant, pentru a avea o imagine în timp real a cantității și tipurilor de material arheologic descoperit, rezultând aşadar o evidență actualizată permanent.

Utilizând stația totală, în cazul de față modelul Leica TCR 407, cât și GPS-ul de mână model Garmin GPSMAP 64, a fost posibilă înregistrarea tuturor punctelor de interes de-a lungul campaniei ${ }^{15}$. Utilizând programul Quantum QIS datele au fost prelucrate şi ordonate în layere (sub formă de puncte, linii și poligoane) fiind folosite în paralel cu cele din campania din anul 2012 și rezultatele prospecțiunilor din anul 2014, dar și cele din anii 2016-2017. Suplimentar față de situația din anii trecuți, am avut acces prin arhiva documentară a Muzeului Național de Istorie a României ${ }^{16}$ la cele mai recente ortofotoplanuri (din 2012) și hărți topografice care le-au înlocuit pe cele de o rezoluție mult mai slabă, utilizate anterior.

Dată fiind efectuarea, în cele două campanii, a cercetărilor arheologice în zona secțiunilor $\mathrm{S}_{032}$ (carourile A-E) și $\mathrm{S}_{033}$ (carourile A-E), iar în campania 2017 și deschiderea noii secțiuni $\mathrm{S}_{034}$ (A-E) paralelă cu $\mathrm{S}_{032}$ și situate către vest de aceasta, trasarea s-a efectuat prin triangulație, fiind ulterior înregistrată de specialiștii din cadrul Platformei Arheoinvest (membri ai colectivului de cercetare al sitului), la finalul campaniei, cu ajutorul unei stații totale ${ }^{17}$. Datele arheologice au fost înregistrate altimetric pe întreaga durată a campaniei arheologice cu ajutorul unei nivele, prin raportare la două puncte fixe din campania 2016: colțul de SE al $\mathrm{S}_{033}(234,62 \mathrm{~m})$ și colțul de $\mathrm{SV}$ al $\mathrm{S}_{032}(234,86 \mathrm{~m})$. S-au făcut reverificări periodice cu ajutorul a 3 borne ce marchează conductele de gaz ce străbat întreg situl arheologic, după cum urmează:

\begin{tabular}{|c|c|c|c|l|}
\hline Denumire & Est & Nord & Altitudine & Observații \\
\hline Borna 1 & 376592.720 & 495125.216 & 237,417 & la sud de secțiunile din campania 2016 \\
\hline Borna 2 & 376698.091 & 495168.289 & 232,175 & ESE de secțiunile din 2016 \\
\hline Borna 3 & 376685.856 & 495284.276 & 229,216 & la NE de secțiunile din 2016 \\
\hline
\end{tabular}

Toate cotele înregistrate au fost integrate în baza de date digitală a sitului și ulterior prelucrate în programul Quantum GIS sub formă de layere. Acestora li se adaugă și peste 200 de puncte,

${ }^{14}$ Biletele de material au fost completate în dublu exemplar, unul regăsindu-se alături de materialul colectat, iar al doilea într-un carnet, pentru a avea o evidență clară și sub control, în timp real. Principalele rubrici dintr-un astfel de bilet au vizat numărul de ordine, unitatea de cercetare (în cazul de față $\mathrm{S}_{032}, \mathrm{~S}_{033}$ și $\mathrm{S}_{034}$ ), caroul (de la A la E), complexul, adâncimea de conturare, adâncimea de la nivelul actual, data, autorul, instituția. Acestora li se adaugă rubrica dedicată observațiilor și categoriei. Pentru cea din urmă au existat valori predefinite în care materialul arheologic putea fi încadrat la ceramică, chirpici / lutuială, piatră, bronz, fier, os sau altele.

15 Mulțumim și pe această cale echipei de topografie arheologică - dr. Andrei Asăndulesei și dr. Felix Tencariu - din cadrul Platformei ARHEOINVEST a Universității „Alexandru Ioan Cuza” (Iaşi), care a efectuat măsurătorile și a transmis - întro primă fază - coordonatele pentru 3 borne fixe, aflate în zona sitului. Totodată în faza finală a săpăturii din ambele campanii, pentru a verifica datele, au fost reînregistrate colțurile secțiunilor și o parte din axele de desen ale complexelor arheologice.

${ }^{16}$ Mulțumim - și pe această cale - dr. Mihai Florea pentru sprijinul colegial acordat în această chestiune.

${ }^{17}$ De asemenea, a fost realizată și georeferențierea unor imagini verticale cu detalii de săpătură, dar și obținerea unui model DSM (digital surface model) pentru zona sitului arheologic sus-menționat. 
înregistrate pe o suprafață de 9-10 hectare ${ }^{18}$, colectate cu ajutorul unui GPS de mână, model Garmin GPSMAP 64. În principiu, acestea localizează concentrări de material ceramic și bucăți de chirpici, observate în perioada lunilor iulie-august 2017, pe întreaga zonă situate către SV și V de zona săpăturii din campaniile 2016-2017, la suprafața arăturii (PI. XIX). În unele cazuri se observă abateri de 1-3 metri, însă este posibilă localizarea în cazul în care se dorește revenirea la anumite puncte. Făcând o scurtă analiză pe baza rezultatelor prospectărilor geomagnetice, aglomerările arheologice corespund cu anomaliile înregistrate prin investigații non-intrusive.

De asemenea, au fost realizate pentru situl hallstattian Tărtăria-Podu Tărtăriei vest o serie de fotografii aeriene din dronă, după cum urmează:

- fotografii aeriene oblice $=15$ fotografii pentru sit și zona imediat învecinată;

- fotografii aeriene verticale $=10$ fotografii pentru sit și zona imediat învecinată.

Acestea sunt utilizate pentru elaborarea documentației de specialitate în vederea parcurgerii procedurilor legale pentru clasarea sitului în Lista Monumentelor Istorice.

DATE SUCCINTE DESPRE MODUL DE PROCESARE POST-SĂPĂTURĂ A MATERIALULUI CERAMIC DESCOPERIT ÎN CADRUL SITULUI

Prima etapă în procesarea materialului ceramic post-săpătură constă în sortarea - de către arheologii membri ai colectivului de cercetare - fragmentelor provenite din fiecare complex în parte. Astfel, încă din această etapă se poate stabili numărul de vase fragmentare sau întregibile pentru fiecare complex, pe baza decorului și a pastei. Acolo unde este cazul, se realizează o întregire temporară a fragmentelor de vase/vase întregibile (prima etapă de conservare). Fiecare fragment de vas / vas întregibil a fost desenat, fotografiat și apoi s-a realizat pentru materialul ceramic din fiecare complex câte o evidență a datelor de referință în format Excel, care cuprinde toate informațiile despre această categorie de descoperiri (număr de fragmente, parte morfologică de vas în care se încadrează fragmentul / fragmentele - margine, corp, bază, toartă sau apucătoare; descriere detaliată a decorului sau a altor elemente semnificative - înclinație margine, curbură corp, formă în profil etc.; tipul de vas din care provine, acolo unde s-a putut stabili; dimensiuni, codul pachetului cf. evidenței primare). Dacă în cursul procesării post-săpătură a materialului ceramic s-a stabilit existența altor vase întregibile, altele decât cele identificate în teren, acestea au primit un cod nou, fiind înregistrate în evidența primară pentru respectiva campanie și având bilet individual. Desenele au fost scanate și apoi prelucrate digital, utilizând programele CorelDraw și Photoshop.

\section{DESCRIEREA COMPLEXELOR ȘI A PRINCIPALELOR DESCOPERIRI (2016-2017)}

\section{Cx 259 ${ }^{19}$ [localizare: $S_{032} \& S_{033}$, carourileA -B] (PI. XXIV-XXV, XXXV/1, XLII/1-2, XLVI/1)}

Complexul a fost conturat prima dată în campania din 2016, inițial în colțul SE al caroului B din $\mathrm{S}_{032}$; cercetarea sa a fost finalizată în campania 2017. Înspre cota inferioară a stratului de cultură hallstattian au fost observate mai multe fragmente ceramice grupate, fără a se putea contura însă o groapă propriu-zisă. Ulterior groapa complexului a putut fi delimitată atât în colțul de NV al caroului A din $\mathrm{S}_{033}$, cât și în colțul de NE al caroului $\mathrm{A}$ din $\mathrm{S}_{032}$. În acest moment al desfășurării săpăturii au fost alocatele siglele (de lucru) Cx $259 \mathrm{~A}, \mathrm{~B}, \mathrm{C}$, reprezentând după cum urmează: Cx 259A - aglomerarea de fragmente ceramice din caroul B al S032, B groapa conturată în carourile $\mathrm{A}$ ale $\mathrm{S}_{032}$ și $\mathrm{S}_{033}$, iar $\mathrm{C}$ - o groapă vizibilă abia după prelevarea fragmentelor de vase sparte in situ din Cx 259 A, situată în colțul de SE al caroului B din $\mathrm{S}_{032}$. Cercetarea complexului a fost continuată și finalizată în campania anului 2017, prin recurățarea părții de V a Cx 259B. Potrivit observatiiilor făcute pe profilul transversal dintre $\mathrm{S}_{032}$ și $\mathrm{S}_{033}$, umplutura gropii începea la adâncimea de $-0,32 \mathrm{~m}(234,25 \mathrm{~m})$ față de nivelul actual de călcare. Imediat sub acest nivel, au fost descoperite mai multe părți de vase puternic fragmentate, alături de bucăți mari de piatră. La adâncimea de $-0,50 /-0,55 \mathrm{~m}(234,10 / 234,05 \mathrm{~m})$ față de nivelul actual de călcare au apărut fragmente de oase de animal, extreme de friabile și alte noi părți de vase sparte pe loc. Cea mai mare parte a complexului, respectiv jumătatea de S nu a putut fi conturată cu ușurință, deoarece aici complexul suprapune marginea nord-vestică a unui complex de mari dimensiuni aparținând culturii Coțofeni (Cx 267). Diferența dintre umpluturile celor două complexe a fost realizată pe baza consistenței

\footnotetext{
${ }^{18}$ Scurtele ,periegheze” au avut loc pe întreaga perioadă a campaniei arheologice, iar pe baza traseelor înregistrate pe GPS, au fost străbătuți peste 10 de km în zig-zag sau paralel.

${ }^{19}$ Prima siglă de complex alocată în campania 2016 este Cx 259, fiind corelat cu cel din campania de cercetare arheologică preventivă din anul 2012.
} 
solului, cea din complexul din perioada timpurie a epocii bronzului fiind mult mai sfărâmicioasă decât cea a gropii hallstattiene Cx 259B; diferențierile de ordin cromatic nu erau evidente, ambele gropi fiind umplute cu un sediment de culoare neagră, pigmentat cu urme de chirpici și cărbune. Alături de fragmentele ceramice și oasele de animal menționate mai sus, inventarului complexului Cx 259B mai cuprindea fragmente mărunte de oase de animal calcinate, chirpici și bucăţi de lemn carbonizat, dar și o mărgea din lut alături de un fragment din gâtul unei căni decorată în stil Basarabi, inclusiv reprezentarea unei păsări acvatice. Odată cu demontarea martorului stratigrafic dintre $S_{032}$ și $S_{033}$ au fost găsite alte fragmente de vase sparte pe loc, două piese mici din bronz, un fragment de râşniță şi câteva fragmente consistente de lipitură de perete. În aceste condiții, a fost posibilă conturarea mai precisă a gropii Cx 259, fiind clar vorba despre un singur complex, de formă ovală, ușor neregulată, alungit pe direcția SV-NE. Lungimea maximă a gropii era de 2,60 m, iar lățimea nu poate fi precizată dată fiind suprapunerea cu Cx 267. Adâncimea maximă de la nivelul actual de călcare era de $-0,60 \mathrm{~m}$ $(234,00 \mathrm{~m})$, iar de la conturare $-0,25 \mathrm{~m}$. Pereții gropii erau uşor tronconici. În partea de nord a complexului, unde inițial au fost marcate Cx 259A și C, au apărut în martorul dintre $\mathrm{S}_{032}$ și $\mathrm{S}_{033}$ aglomerări de fragmente ceramice și chirpici. După prelevarea acestora s-a conturat o altă groapă de formă circulară, cu diametrul de circa 1,2 m, „tangentă” cu groapa Cx 259B. Nu s-a putut observa vreo diferență între umpluturile celor două gropi, astfel că - cel mai probabil - în acest caz era vorba de un singur complex de dimensiuni medii, care a primit sigla finală Cx 259 .

În stadiul actual al procesării post-săpătură a materialului ceramic provenit din acest complex, au putut fi identificate patru vase întregibile / fragmente de vase și anume: cană cu decor tipic Basarabi, cu reprezentarea unei păsări acvatice (PI. XLII/2); vas tip borcan întregibil (PI. XLII/1); partea inferioară a unui vas bitronconic nedecorat și un vas bitronconic, fragmentar.

\section{Cx 260 [localizare: $S_{032}$, caroul B] (PI. XXXIII/3)}

Complex de mici dimensiuni $\left(0,31 \times 0,25 \mathrm{~m}\right.$ şi o suprafaţă de $\left.0,05 \mathrm{~m}^{2}\right)$, cu material arheologic descoperit la $-0,30 \mathrm{~m}$ adâncime față de nivelul actual, respectiv $-0,38 \mathrm{~m}$ în cazul fragmentului de ceașcă. La baza stratului de cultură a fost observată o aglomerare de chirpici, de formă aproximativ circulară şi cu diametrul de circa $20 \mathrm{~cm}$, alături de alte fragmente ceramice atipice, răspândite în jurul său. Imediat la SV de aglomerare, la $-0,38 \mathrm{~m}$ a fost descoperită o ceașcă fragmentară, decorată în stil Basarabi. Nu s-a putut contura nici o groapă în jurul aglomerării de material arheologic, acesta fiind așezat direct pe sol.

\section{Cx 261 [localizare: $S_{033}$, caroul B și extinderea acestuia din partea de NNE] (PI. XXVI)}

Complexul a fost conturat iniţial în campania din 2016, în colţul de NE al caroului B din $\mathrm{S}_{033}$; cercetarea sa a fost finalizată în campania 2017. Pentru început a fost deschisă o casetă spre nord, în caroul C, şi spre est, pentru conturarea părții nordice a gropii. De la început, au fost observate la suprafața complexului mai multe fragmente ceramice, oase de animal foarte friabile și câteva pietre. În campania din $2017 \mathrm{~s}-\mathrm{a}$ demontat martorul dintre carourile B și C al S $S_{033}$ și s-a deschis o casetă de 3,1 × 2,85 m, lățită cu 1 m spre est faţă de caroul C, pentru conturarea finală a complexului. Acesta a fost observat inițial sub forma unei pete ovale, alungite, cu dimensiuni aproximative de 2,4 × 1,6 m; secționarea gropii s-a făcut pe axa V-E. În primul nivel al umpluturii gropii a apărut o cantitate însemnată de material arheologic (fragmente ceramice, pietre mari friabile, oase de animal în poziție neanatomică, fragmente de lipitură de perete) concentrate în partea centrală a gropii. Acestea au fost observate la adâncimea de $-0,35$ m (234,05 m) față de nivelul actual de călcare. Sub acest prim nivel, concentrarea de material arheologic nu mai era aşa de însemnată și a putut fi observată schimbarea culorii umpluturii. Astfel, dacă în nivelul superior umplutura gropii era constituită dintr-un sediment de culoare neagră, puternic pigmentat cu urme de chirpici și cărbune, în cel de-al doilea nivel (de umplere al gropii) sedimentul avea culoarea negru-maroniu, gălbui pe alocuri, fiind puțin pigmentat cu urme chirpici și cărbune, iar materialul era răspândit în umplutură. Spre partea de est a complexului s-a conturat o groapă (anexă a gropii observată inițial), care se adâncește până la $-0,70 \mathrm{~m}$ (233,45 m) față de nivelul de conturare, de unde se „cuptorea” puternic spre est până la adâncimea de circa $-0,9 \mathrm{~m}$ $(233,25$ m) față de nivelul de conturare. Această ,cuptorire” se extindea până la 0,4 m spre E faţă de nivelul la care a fost conturat complexul. Umplutura era compactă în această a doua groapă, fiind uşor pigmentată și având puţin material arheologic, majoritatea provenind din partea sa inferioară, respectiv de la o singură cană decorată în stil Basarabi. Alături de acestea au apărut și câteva fragmente de lut ars și nears, dar și chirpici cu amprente. Jumătatea nordică s-a extins mult față de conturarea inițială. Baza complexului era denivelată, pereții fiind neuniformi, ușor „cuptoriți” în partea de N. Adâncimea era de $-0,5 \mathrm{~m}(233,60 \mathrm{~m})$ față de nivelul de conturare. Forma finală a complexului era aproximativ circulară, cu dimensiuni de $2 \times 2,5 \mathrm{~m}$, fără a lua în considerarea groapa adiacentă „,cuptorită”, din partea de E, care are diametrul de $0,9 \mathrm{~m}$.

În stadiul actual al procesării post-săpătură a materialului ceramic provenit din acest complex, au putut fi reconstituite preliminar trei vase întregibile / fragmente de vase. 


\section{Cx 262 [localizare: $S_{032}$, caroul C] (PI. XXVII)}

Complexul de formă aproximativ ovală (1,52 m pe axa NE-SV, 1,38 pe axa NV-SE, cu o suprafaţă totală de $\left.1,58 \mathrm{~m}^{2}\right)$ a fost identificat imediat sub nivelul vegetal, la $-0,31 \mathrm{~m}(234,123 \mathrm{~m})$ în partea de est, respectiv la $-0,30 \mathrm{~m}$ în cea de vest. Adâncimea finală, raportată la nivelul actual de călcare era de $-0,73 \mathrm{~m}$ în zona centrală. Suplimentar au fost măsurate și alte cote de la conturare pe latura de nord-est $(234,111 \mathrm{~m})$, sudest $(234,105$ m), sud-vest $(234,108)$ și nord-vest $(234,123)$. Aparent această groapă era în conexiune cu Cx 263 , având aceeași umplutură, respectiv un sediment de culoare neagră cu multiple urme de chirpici și cărbune și un sediment galben-cafeniu, ușor pigmentat cu chirpici și cărbune pe margini. În umplutură au apărut fragmente ceramice tipice perioadei Basarabi, dar și atipice, posibile bucăți de gardină, fragmente puternic degradate de oase de animal, bucăți mici de chirpici și un fragment de gresie, fățuită, probabil un rest dintr-o râșniţă $(20 \times 11$ $\times 3 \mathrm{~cm})$.

\section{Cx 263 [localizare: $S_{032}$, caroul C] (PI. XXVII-XXVIII, XXXII, XXXIII/2, XLIII/3)}

Complexul avea formă ovală în plan (1,55 m pe axa NV-SE și $1,10 \mathrm{~m}$ pe axa NE-SV și suprafața de $1,35 \mathrm{~m}^{2}$ ), fiind situat la vest de Cx 262, aparent în conexiune cu acesta și la același nivel (antic de călcare). Imediat după secționare, în jumătatea de sud a fost descoperită jumătate dintr-o strachină cu buza puternic răsfrântă spre exterior, decorată în stil Basarabi, puternic fragmentată. Pentru a observa cât mai precis modul de dispunere a materialului în groapă s-a curățat și jumătatea de nord a complexului, unde a apărut o altă aglomerare de fragmente ceramice, provenite de la un vas bitronconic, puternic fragmentat, dar și jumătate dintr-o ceașcă, ambele decorate în stil Basarabi. După prelevarea vaselor s-a putut observa că groapa se adâncea până la $-0,50$ m față de nivelul actual, partea inferioară a umpluturii constând dintr-un sol galben-cafeniu, ușor pigmentat cu chirpici și cărbune. Inventarul arheologic cuprinde pe lângă cele 3 vase menţionate mai sus, alte fragmente de ceramică tipică și atipică din aceeași perioadă, fragmente mărunte de chirpici și oase de animal, în stare precară de conservare.

\section{Cx 264 [localizare: $S_{032}$, caroul D] (PI. XXIX/ 4-6)}

Complexul de formă circulară $\left(D_{\max }\right.$ aprox. $1,20 \mathrm{~m}$, suprafața: $\left.1,11 \mathrm{~m}^{2}\right)$ a fost conturat la $-0,33 \mathrm{~m}$ față de nivelul actual de călcare, respectiv 233,96 m în partea de est și la 233,97 m în partea de vest. În partea de nord a gropii, aproximativ la $-0,1 \mathrm{~m}$ de la conturare a apărut o bucată mare de gresie fățită, ruptă în două fragmente, cu dimensiuni de $28 \times 16 \times 8 \mathrm{~cm}$. Umplutura gropii consta dintr-un sol negru-cafeniu cu pigment de chirpici şi cărbune, din care au fost prelevate mai multe fragmente ceramice atipice, dar și tipice perioadei Basarabi şi câteva fragmente de chirpici fără amprente.

\section{Cx 265 [localizare: $S_{032}$, caroul D] (PI. XXX, XXXI/4, XXXIV/4-6)}

Complexul avea formă ovală în plan $\left(1,75 \mathrm{~m}\right.$ pe axa N-S și $1,30 \mathrm{~m}$ pe axa E-V, suprafaţa de $\left.1,80 \mathrm{~m}^{2}\right)$ și a fost conturat la $-0,35 \mathrm{~m}$ adâncime în partea de $\mathrm{V}(233,96 \mathrm{~m}),-0,29 \mathrm{~m}$ în zona centrală și la $-0,33 \mathrm{~m}$ în partea de est $(233,96 \mathrm{~m})$. După secționarea gropii pe axa S-N, în jumătatea de est, aproximativ în centrul complexului, a apărut o aglomerare de bucăți de lipitură de perete (?), pe partea fățiită având o culoare albă, iar pe partea opusă s-a putut observa că au încastrate bucăţi de ceramică decorată în stil Basarabi (,,S”-uri înlănţuite, încadrate de două şiruri de impresiuni oblice, triunghiuri haşurate pe interiorul buzei, iar pe exterior apar aceleași „S”-uri încadrate de puncte imprimate din care pornesc ghirlande din minim 5 puncte imprimate). Cel mai mare fragment, în greutate de 410 grame, are dimensiuni de $112 \times 94 \times 40 \mathrm{~mm}$, iar cea mai mare bucată în care se pot observa bucăți de ceramică, de fapt și prima piesă identificată în teren în profilul gropii, cântărește 347 de grame și are dimensiuni de $111 \times 98 \times 38$ mm. De remarcat că în cazul unei bucăți $(103 \times 56 \times 30 \mathrm{~mm})$, în zona amprentei cu fragmente ceramice (?), s-au observat mici bucăţi organice, lemn (?), carbonizate, care din păcate nu au putut fi prelevate din cauza stării foarte proaste de conservare.

Aglomerarea de lipitură a fost observată la $-0,60 \mathrm{~m}$ de la nivelul actual, iar adâncimea maximă a acestei depuneri atinge $-0,80$ m în zona centrală. Jumătatea de est a gropii s-a extins considerabil faţă de conturarea inițială. În umplutura gropii, constând dintr-un sediment de culoare neagră, puternic pigmentat cu chirpici și cărbune, a apărut o cantitate mare de fragmente ceramice tipice perioadei culturii Basarabi și atipice, inclusiv câteva vase întregibile (cești, vas bitronconic, vas borcan), probabil un picior de vas (vas suport sau vas „fructieră”) decorat cu „S”-uri înlănțuite și șnur fals, precum și mai multe fragmente de lut ars cu și fără amprente.

Cx 266 [localizare: $S_{032,}$ martorul dintre caroul $C$ și D] (PI. XXX, XXXI/1-4, XXXIII/1, XXXV/2-3)

Complexul de formă ovală $\left(1,25 \mathrm{~m}\right.$ pe axa E-V, 0,95 m pe axa N-S și suprafața de $\left.0,99 \mathrm{~m}^{2}\right)$ a fost conturat în partea de est la $-0,22 \mathrm{~m}$ sub nivelul actual $(234,069)$ și în cea de vest la $-0,30 \mathrm{~m}(234,079)$. La conturarea gropii a fost observată o cantitate mare de fragmente ceramice, care - după adâncirea cu aproximativ $5 \mathrm{~cm}$ a săpăturii - s-a dovedit că provin de la mai multe vase sparte pe loc (vas bitronconic, cană). Materialul arheologic a fost concentrat în zona centrală a gropii, limitele complexului extinzându-se mult spre vest și est. 
De notat că fragmente din cana descoperită în centrul complexului au apărut și în umplutura Cx 263, iar un fragment mare de râșniță se întregește cu o altă parte de râșniță din Cx 268.

\section{Cx 267 [localizare: $S_{032} /$ caroul A și $S_{033} /$ caroul A] (PI. XXXIV/1-3, XXXVI/5)}

Complex de mari dimensiuni, observat în profilul de sud al ambelor secțiuni, pe o suprafață de peste 6 $\mathrm{m}^{2}$. Dată fiind situația diferită față de restul complexelor, dar și nevoia păstrării unui martor intermediar perpendicular pe profilul magistral E-V - s-a procedat la atribuirea a două denumiri potrivit punctelor cardinale în care se aflau, Cx 267 V şi Cx 267 E. În umplutură au fost descoperite fragmente ceramice specifice culturii Coțofeni, aceste provenind mai ales din partea inferioară a depunerii (-1/-1,5 m de la nivelul actual de călcare). Având în vedere dimensiunile considerabile, dar obiectivele primelor două campanii de săpături sistematice în cuprinsul acestui sit, săparea complexului s-a realizat numai parțial, finalizarea cercetării sale urmând să fie făcută într-o campanie viitoare.

\section{Cx 268 [localizare: $S_{032}$, caroul D] (PI. XXIX/1-4)}

Complex de formă ovală $\left(0,96\right.$ m pe axa NV-SE, $0,82 \mathrm{~m}$ pe axa NE-SV, suprafață de $\left.0,61 \mathrm{~m}^{2}\right)$, care a fost conturat la $-0,28$ / $-0,30 \mathrm{~m} \mathrm{NE}$ de Cx 264. In partea de est a putut fi identificat la $-0,35 \mathrm{~m}$ faţă de nivelul actual $(233,85 \mathrm{~m})$, în vest la $-0,36 \mathrm{~m}(233,86 \mathrm{~m})$, iar în partea centrală la o cotă superioară, la $-0,30$ m datorită unei bucăți de piatră șlefuită, așezată pe cant. Conturarea acestei gropi a fost posibilă după mai multe curățări în partea de nord a Cx 264, cel mai probabil cele două complexe aflându-se în conexiune la un moment dat. Alături de fragmentul de râșniță au mai fost descoperite câteva fragmente ceramice tipice perioadei Basarabi și atipice, precum și un fragment de lutuială situat la NV de râșniță și o bucată de calcar de dimensiuni considerabile.

De remarcat că bucata de râșniță din acest complex se completează cu cea din Cx 266.

\section{Cx 269 20 [localizare: $S_{033}$, caroul D] (PI. XXXVI/1-4)}

Groapă de mici dimensiuni, situată în colțul de SE al caroului D al $S_{033}$, conturată în nivelul stratului de cultură sub forma unei aglomerări circulare de material ceramic și chirpici. Groapa a fost umplută cu un sediment de culoare neagră, cu urme de chirpici și cărbune; în profil, groapa avea o formă concavă. Dimensiunile finale ale complexului erau $0,95 \times 0,8 \mathrm{~m}$, iar adâncimea maximă de $-0,4 \mathrm{~m}(233,65 \mathrm{~m})$ faţă de nivelul actual de călcare.

\section{Cx 270 [localizare: $S_{034}$, caroul A] (PI. XXXVII)}

Complexul a fost conturat în colțul de SE al caroului A din $S_{034}$, inițial sub forma unei aglomerări de material arheologic, situată într-un sol negru intens, puternic pigmentat cu chirpici, aflat imediat sub nivelul vegetal, la $-0,33 \mathrm{~m}(234,60 \mathrm{~m})$. În umplutura sa au fost descoperite mai multe părți de vase sparte pe loc, fragmente de lut ars, fragmente mărunte de cărbune, oase calcinate şi pietre, inclusiv o râşniţă fragmentară. Spre baza gropii s-a observat o schimbare a caracteristicilor sedimentului - un sol negru-maroniu mai puțin dur, dar compact. Tot în această zonă materialul arheologic nu mai era aşa de numeros, deși în această parte au fost descoperite fragmente de oase de animal și o zonă de arsură (având dimensiuni de $0,3 \times 0,3 \mathrm{~m}$ ), cu posibile resturi dintr-o vatră sau o altă structură de combustie. Adâncimea finală a gropii, față de nivelul actual de călcare, era de $-0,62 \mathrm{~m}(234,32 \mathrm{~m})$. Pentru conturarea părții de est a complexului a fost demontat martorul dintre $\mathrm{S}_{032}$ și $\mathrm{S}_{034}$; delimitarea gropii a putut fi făcută în acest context. Forma finală a gropii era ovală, alungită pe direcția V-E, cu dimensiunile de $1,42 \times 1 \mathrm{~m}$.

În stadiul actual al procesării post-săpătură a materialului ceramic provenit din acest complex, au putut fi reconstituite preliminar trei vase întregibile / fragmente de vase.

\section{Cx 271 \& Cx 274 [localizare: $S_{034}$, caroul C] (PI. XXXVIII-XXXIX, XLIII/1-2, XLVI/2)}

Complexul identificat cu sigla Cx 271 a fost observat în colțul de SV al caroului C din $\mathrm{S}_{034}$, înspre cota inferioară stratului de cultură hallstattian, la adâncimea de $-0,30 /-0,35$ m (234,30 / 234,25 m) față de nivelul actual de călcare. Delimitarea complexului s-a făcut iniţial pornind de la aglomerarea de material arheologic, dar conturarea gropii nu a fost posibilă de la început. La nivelul preliminar de conturare, a apărut un vas spart pe loc în partea de vest a complexului și o altă concentraţie de fragmente ceramice spre est. În umplutura de culoare neagră a gropii au apărut mai multe fragmente ceramice, chirpici și pietre, majoritatea concentrate în partea superioară a depunerii. La aproximativ $-0,15$ m faţă de nivelul de conturare, culoarea umpluturii se schimba uşor, fiind observat un sediment cafeniu negricios, slab pigmentat. La adâncimea de $-0,2 \mathrm{~m}$ față de cota de conturare $(234,07 \mathrm{~m})$, în partea centrală a gropii au fost identificate mai multe fragmente ceramice grupate la un loc, provenite probabil de la un vas grosier de mari dimensiuni (au putut fi reîntregite părți din gâtul înalt) şi marginea unui alt vas mare bitronconic. Alături de acestea au fost găsite fragmente de lipitură de perete, bucăți

\footnotetext{
20 Prima siglă de complex utilizată în campania 2017 este Cx 269, în continuarea sistemului de numerotare utilizat în campania precedentă.
} 
de lut puternic ars (de culoare neagră), friabil, imposibil de prelevat datorită stării de conservare, dar și o piatră de dimensiuni mai mari. Partea de vest a complexului a fost dificil de conturat, deoarece imediat sub nivelul vegetal materialul arheologic se răspândea mult spre vest, în afara limitei Cx 271; foarte probabil în această zonă este situat un alt complex, care însă nu a mai putut fi cercetat în campania din 2017. Spre S a fost demontat martorul dintre carourile $\mathrm{B}$ și $\mathrm{C}$ ale $\mathrm{S}_{034}$ pentru stabilirea limitei sudice a complexului. Pe acelaşi nivel de conturare $(234,25 \mathrm{~m})$ a apărut o altă aglomerare de material arheologic, dispus pe o suprafață aproximativ circulară, care constituia - în mod evident - un alt complex. Acesta a fost identificat cu sigla Cx 274, fiind conturat la $-0,30$ m $(234,30 \mathrm{~m})$ față de nivelul actual de călcare. Pentru verificarea „relației” dintre cele două complexe, noul complex a fost secționat pe direcția N-S. Astfel, s-a observat că Cx 274 taie groapa Cx 271, diferența fiind dată de umplutura gropilor. Cx 274 a fost umplută cu sediment mult mai închis la culoare decât cel din Cx 271, respectiv de culoare neagră intensă, cu foarte multe urme de arsură. Sub aglomerarea de fragmente ceramice, numeroase și de dimensiuni mici de la nivelul conturare, în umplutura Cx 274 au apărut mai multe vase sparte pe loc, anume: un vas bitronconic decorat în stil Basarabi, situat cu baza în sus (lipsește complet marginea și partea superioară a gâtului vasului); o strachină de mari dimensiuni, cu pereții tronconici și o parte din bază lipsă, decorată în partea superioară în stil Basarabi (singura strachină de acest tip și dimensiuni descoperită până în prezent în situl hallstattian Tărtăria-Podu Tărtăriei vest, care se întregește în proporție de 95\%); un vas de tip borcan întregibil. Se adaugă mai multe fragmente de râșniță și calupuri mari de lut ars. Pe baza analizei preliminare a materialului ceramic, ambele gropi sunt relativ contemporane și, având în vedere dispunerea față de Cx 273 (foarte probabil un bordei), este posibil ca acestea să fi fost anexe ale acestuia. Din punct de vedere al funcționalității, cel puțin Cx 274 reprezintă o groapă de provizii, date fiind vasele aproape întregi găsite aici, dar și forma „,cuptorită”. Cx 271 conține fragmente ceramice de la mai multe vase, majoritatea de dimensiuni mari, dar care nu s-au reîntregit ulterior, astfel că aceasta reprezintă probabil - mai degrabă - o groapă menajeră. Dimensiunile finale ale Cx 271 erau de 1,72 × 1 m, adâncime $-0,35$ m $(233,95$ m) de la nivelul de conturare, iar Cx 274 avea un diametru de circa $1 \mathrm{~m}$ şi adâncimea de aproximativ $-0,60 \mathrm{~m}$ $(233,70 \mathrm{~m})$ de la nivelul conturare.

În stadiul actual al procesării post-săpătură a materialului ceramic provenit din $\mathrm{Cx} 271$, au putut fi identificate trei vase întregibile / fragmente de vase și anume: fragmente de la două vase mari bitronconice (partea superioară, corp cu decor, bază și alte fragmente mai mici) și un vas întregibil, bitronconic, nedecorat, căruia îi lipsește complet marginea.

În stadiul actual al procesării post-săpătură a materialului ceramic provenit din $\mathrm{Cx} 274$, au putut fi reconstituite șapte vase întregibile / fragmente de vase și anume: o ceașcă întregibilă, cu marginea răsfrântă spre interior (,,invazată”) și toartă supraînălțată, nedecorată; fragmente diverse de la un vas de tip borcan, care însă nu se întregește; un alt vas de tip borcan, întregibil; un vas bitronconic cu decor Basarabi, fără margine, fragmente de la un al treilea vas de tip borcan, de mari dimensiuni, care însă nu se întregește; partea inferioară a unui vas bitronconic și o strachină mare întregibilă (cu margine lipsă în mare parte), cu decor Basarabi.

\section{Cx 272 [localizare: $S_{034}$, caroul C] (PI. XL, XLII/3-4)}

Complexul a fost identificat în colțul de NV al caroului $\mathrm{C}$ din $\mathrm{S}_{034}$, sub forma unei aglomerări de material arheologic dispus pe o suprafață relativ circulară, cu diametru de aproximativ 0,6 m, fără a fi vizibil conturul propriu-zis al unei gropi. Conturarea inițială a fost realizată la $-0,45$ m (234,00 m) față de nivelul actual de călcare, spre cota inferioară a stratului de cultură hallstattian, iar încă 0,15 m mai jos a fost posibilă delimitarea unei gropi de formă circulară, cu diametrul de aproximativ $1 \mathrm{~m}$. Umplutura gropii se distingea faţă de stratul de cultură prin puternica pigmentare cu chirpici și o concentrare însemnată de material arheologic. În umplutura acestei gropi au fost găsite pietre de mari dimensiuni, un calup de lut nears cu diametrul de 0,2 m, iar sub acesta cel puțin două vase mici fragmentare. Printre acestea a fost identificat și un fragment de lut puternic ars (negru), de formă alungită dreptunghiulară (cu lungime de circa $30 \mathrm{~cm}$ ), imposibil de prelevat întreg din cauza stării de conservare și a cărui utilitate este incertă. Adâncimea finală a gropii era de maxim $0,2 \mathrm{~m}$ față de nivelul de conturare $(233,80 \mathrm{~m})$.

În stadiul actual al procesării post-săpătură a materialului ceramic provenit din acest complex, au putut fi reconstituite preliminar două vase întregibile / fragmente de vase: ceașcă (?) sau castron miniatural, fragmentar, fără toartă; fragmente dintr-o ceașcă cu marginea ușor ,invazată”, gât scurt, corp bombat, toartă lipsă, nedecorată, care nu se întregește.

\section{Cx 273 [localizare: $S_{034}$, carourile A și B] (PI. XLI, XLVI/4)}

Acest complex de mari dimensiuni a fost conturat în cuprinsul a două carouri, fiind iniţial vizibil aparent sub forma a cel puțin două gropi diferite. Acesta a apărut la cota inferioară a stratului de cultură hallstattian, în jumătatea nordică a caroului B al $\mathrm{S}_{034}$, astfel că delimitarea sa exactă a fost posibilă abia numai după adâncirea, prin săpătură la vârf de cazma și răzuieli succesive, cu 0,10/0,15 m față de acest nivel. Partea de sud a complexului a apărut că se extinde în cea mai mare parte a suprafeței caroului A din $\mathrm{S}_{034}$, dar ulterior acesta s-a restrâns aproape cu jumătate în suprafață, având o formă oval neregulată, fiind mai lată în partea 
nordică (care intra sub martorul dintre carourile A și B ale $S_{034}$ ). Jumătatea de nord a complexului a fost vizibilă pe aproximativ 2/3 din suprafața caroului B al $S_{034}$, depășind limitele unității de cercetare, atât spre sud cât și spre sud-est. Pentru o delimitare cât mai precisă s-a demontat martorul dintre $S_{032}$ și $S_{034}$ şi s-a redus la jumătate martorul dintre carourile $\mathrm{A}$ și $\mathrm{B}$ ale $\mathrm{S}_{034}$. Ulterior s-a putut stabili existența unui singur complex, de mari dimensiuni, astfel că secționarea acestuia s-a realizat ,în cruce”, cu un martor pe axa V-E de la nivelul actual de călcare $(234,87 \mathrm{~m}$ spre latura de vest și $234,74 \mathrm{~m}$ spre latura de est) și unul pe axa N-S de la nivelul de conturare. Jumătatea sudică a complexului nu se adâncea foarte mult. Adâncimea gropii cobora de la $-0,15 \mathrm{~m}$ (de la nivelul de conturare) în partea de sud până la $-1,20$ m (de la nivelul actual), înspre nord, conform observațiilor realizate pe profilul V-E. Materialul arheologic a fost concentrat în partea superioară a umpluturii, într-un sediment de culoare neagră cu urme de chirpici și cărbune. Alături de fragmente ceramice, au apărut câteva pietre, bucăți de lut ars, probabil de la o structură de combustie (distrusă), fragmente de oase de animal, urme de cărbune și un vas (?) din lut ars, cu pereții foarte groși, destul de friabil, având formă semisferică (posibil o vatră portabilă). Partea nordică a complexului, cea din caroul B, se adâncea până la $-1,7 \mathrm{~m}(233,09 \mathrm{~m})$ față de nivelul actual de călcare. În această parte groapa avea o formă aproximativ circulară, iar partea inferioară a complexului s-a „,cuptorit” de jur împrejurul său. Și în acest caz, o mare cantitate de material arheologic (ceramică în special, dar și lipitură de pereți, bucăţi de vatră, alte fragmente de chirpici sau oase de animal) a fost concentrată în partea superioară a umpluturii, după care a fost observat un alt sediment cu consistență nisipoasă, negru-cenușiu, urmat de un sediment galben-cenușiu, nisipos, și acesta cu o concentrație mare de material arheologic (la o primă observație pare a fi vorba de material ceramic mai timpuriu față de cel Basarabi „clasic”, cu multă ceramică fină, lustruită, neagră la exterior și decor diferit - foarte probabil reprezentând o fază mai timpurie). Înspre baza complexului umplutura era puternic pigmentată cu oxizi de fier. Solul umed şi nisipos din această parte a făcut posibilă și păstrarea în condiții relativ bune a oaselor de animal (putând fi prelevată o cantitate cu mult mai însemnată cantitativ comparativ cu alte situații documentate până acum în cuprinsul sitului hallstattian Tărtăria-Podu Tărtăriei vest). Pe latura de vest a complexului, în caroul B al $\mathrm{S}_{034}$ a fost vizibilă o suprafaţă de aproximativ $-0,5 \mathrm{~m}$ cu multă arsură roșiatică și fragmente de lut ars dispersate pe suprafața imediat învecinată (fără a avea o formă clară), situată în partea „cuptorită” a complexului, care ar putea indica prezența unei structuri de combustie. După demontarea martorilor s-a observat prezența unei gropi „principale”, de formă aproximativ circulară cu diametrul de circa 3,10 m, ,cuptorită” în partea inferioară, cu o extensie spre sud, astfel că lungimea totală a complexului era de 5,05 m. Având în vedere cele observate, se poate considera că funcționalitatea complexului va fi fost de locuință adâncită / bordei, având zona de acces în partea de sud. $\mathrm{Nu}$ au fost observate gropi de par nici în interiorul, nici în exteriorul complexului, acest fapt datorându-se foarte probabil lucrărilor agricole moderne, care afectează în mare măsură partea superioară a depunerii arheologice în care se păstrează vestigiile hallstattiene. Luând în considerare proximitatea complexelor Cx 270 (către sud-est), Cx 271 și Cx 274 (către nord), în cadrul cărora au fost găsite mai multe vase sparte pe loc, fragmente de râşniță, pereți cu urme de bârne și nuiele sau calupuri de lut ars, este foarte probabil ca acestea să reprezinte anexe ale bordeiului Cx 273.

În stadiul actual al procesării post-săpătură a materialului ceramic provenit din acest complex, au putut fi reconstituite preliminar trei vase întregibile / fragmente de vase.

\section{ÎN LOC DE CONCLUZII}

Luând în considerare rezultatele preliminare ale primelor două campanii de cercetare arheologică sistematică în cuprinsul acestui sit este cert faptul că ipotezele formulate în anul $2012 \mathrm{cu}$ privire la întinderea sitului au fost confirmate, deopotrivă având în vedere și investigațiile geofizice (2014, 2016 și 2017). Stațiunea preistorică ocupă o suprafață apreciabilă pe platoul denumit „Podu Tărtăriei", dar realizarea lucrărilor moderne și contemporane de infrastructură au avut impact asupra laturilor sale de nord, est și sud. Însă situl este în pericol de a fi distrus prin lucrările agricole intensive care se desfășoară pe întreaga sa suprafață. Deși prospectările geomagnetice din toamna anului 2017 au oferit o serie de indicii importante, încă nu a putut fi stabilită limita vestică a sitului. Așadar, situl hallstattian Tărtăria-Podu Tărtăriei vest este - în acest moment - unul dintre cele mai importante (prin dimensiuni, caracteristici și descoperiri) din repertoriul „culturii” Basarabi. În egală măsură, inventarul complexelor cercetate în campaniile 2016-2017 reconfirmă observațiile realizate cu prilejul săpăturilor arheologice preventive din anul 2012, anume prezența unei cantități apreciabile de ceramică tipică stilului Basarabi, spartă pe loc, în numeroase cazuri asociate cu piese din metal (bronz și fier). Deși aflate într-un stadiu preliminar de procesare și analiză post-săpătură, materialele arheologice descoperite în această campanie sunt însemnate, dacă este să luăm în considerare fie numai cele peste 20 de vase întregi / întregibile, tipice pentru repertoriul de forme și motive specific acestui stilul ceramic preistoric, dar și piesele din metal (trei din fier și una din bronz) descoperite în 
contexte arheologice certe. Efectuarea unor serii mai ample de analize 14C în laboratorul RO-AMS din cadrul Institutului de Fizică și Inginerie Nucleară „Horia Hulubei”, pe baza probelor osteologice prelevate atât în campania anului 2016, dar și în aceasta oferă noi date certe privind încadrarea cronologică a sitului și reconsiderări importante referitoare la cronologia „culturii Basarabi”, în sensul unei datări mai timpurii a începuturilor acestora (în a doua jumătate a secolului al IX-lea a. Chr.). De altfel, și observațiile preliminare asupra loturilor ceramice $(2012,2016,2017)$ descoperite în situl hallstattian Tărtăria-Podu Tărtăriei vest converg cu aceste prime datări AMS, de vreme ce sunt sesizabile - în inventarul unora dintre complexe (PI. XLVIII-L) - asocieri de materiale aparținând orizontului cultural cu ceramică neagră canelată de tip Gáva cu cele de tip Basarabi (timpurii), dar și al celor de „tradiție” Gornea-Kalakača cu ceramică de tip Basarabi (faza timpurie); aceste descoperiri se adaugă semnalărilor mai vechi referitoare la descoperirile de acest fel din Transilvania, precum cele provenite din descoperiri fortuite din zona acestui sit sau din vecinătatea acestuia, ca de exemplu de la Teleac $^{21}$, Lancrăm-Glod ${ }^{22}$, Micești-Cigașe ${ }^{23}$. În perspectivă, odată cu publicarea monografică a descoperirilor de la Tărtăria-Podu Tărtăriei vest, acestea vor putea fi studiate comparativ cu materialele similare din importanta așezare de la Gradina na Bosutu ${ }^{24}$, dar și cu alte descoperiri inclusiv cele mai noi ${ }^{25}$ - din această perioadă din zona actuală a Serbiei.

Continuarea cercetărilor arheologice sistematice în cuprinsul acestui sit este foarte necesară dintr-o serie de considerente care determină trei obiective pe termen scurt / mediu pentru investigațiile viitoare. În primul rând este vorba despre stabilirea limitei vestice a sitului, pentru aceasta impunându-se deopotrivă finalizarea prospectărilor geomagnetice în această parte a sitului și sondarea zonei de interes astfel stabilite. Chiar dacă au putut fi realizate numai preliminar, investigațiile prin mijloace non-intrusive din toamna 2017 oferă indicii foarte importante privind delimitarea sitului către vest. De asemenea, situl este amenințat de a fi distrus prin continuarea practicării agriculturii intensive; perieghezele efectuate în anii 2016 și 2017 pe suprafața sa arată foarte clar impactul negativ pe care arăturile, chiar dacă nu foarte adânci, realizate pe întreg arealul stațiunii îl au asupra vestigiilor arheologice. Și din această perspectivă, trebuie continuate cercetările de teren, deopotrivă prin săpătură sistematică în noi perimetre din cuprinsul sitului, dar şi cele pluridisciplinare. Nu în ultimul rând, o prioritate este realizarea clasării sitului în Lista Monumentelor Istorice - solicitată încă de la începutul anului 2013 de către autorii săpăturii preventive - dar și identificarea de către autorități a unor modalități concrete prin care impactul lucrărilor agricole asupra vestigiilor arheologice de aici să fie atenuat.

Cât privește obiectivele specifice, date fiind caracteristicile sitului, precum și felul, diversitatea și amploarea descoperirilor efectuate până în prezent în cadrul acestei stațiuni preistorice, în continuare se va desfăşura programul multianual de cercetare pluridisciplinară (pentru moment planificat până în anul 2020), structurat pe următoarele teme prioritare: definirea limitelor sitului; clarificarea modului său de delimitare (fortificare?) și a necesității acestui „sistem” în perioada Hallstatt-ului mijlociu(c. Basarabi); stabilirea funcționalității sitului (așezare fortificată versus ,arie de depunere") în perioada mijlocie a primei epoci a fierului, în special având în vedere cele două depozite de piese din bronz și fier descoperite în ,șanțul sudic de delimitare"26.

\section{BIBLIOGRAFIE}

Borș et alii 2014

Borș 2015
C. Borș, L. Irimuș, V. Rumega, S. Dobrotă, C. Rișcuța, Un nou sit de tip Basarabi. Raport arheologic preliminar asupra cercetărilor arheologice preventive de la Tărtăria-Podu Tărtăriei vest (campania 2012), CA, XX, 2013 (2014), p. 9-102

C. Borş, Depozitele de bronzuri Tărtăria I și Tărtăria II, în vol. Artizanii epocii bronzului: descoperiri recente de depozite de bronzuri în județul Alba (catalog de expoziție), Alba Iulia, 2015, p. 51-64

\footnotetext{
${ }^{21}$ Ciugudean 2009, 319-320.

${ }^{22}$ Popa, Simina 2004, 32-35.

${ }^{23}$ Rustoiu 1999, 103.

${ }^{24}$ Medović, Medović 2011.

25 Jevtić 2016.

${ }^{26}$ Borș 2015, 51-64.
} 
Borș et alii 2017

Ciugudean 2009

Craiovan, Micle 2015

Dumitrașcu, Ene, Streinu 2016

Ferencz, Roman 2015

Jevtić 2016

Luca 2016

Medović, Medović 2011

Popa, Simina 2004

Rogozea 2016

Rogozea et alii 2017

Rustoiu 1999
C. Borş, L. Rumega-Irimuş, V. Rumega-Irimuş, Mădălina Voicu, A. Asăndulesei, F. Tencariu, R. Balaur, Situl hallstattian Tărtăria-Podu Tărtăriei vest, $C C A, 2017$, nr. 77, p. 139-141

H. Ciugudean, Câteva observații privind cronologia așezării fortificate de la Teleac, Apulum, XLVI, 2009, p. 311-336

B. Craiovan, D. Micle, O frescă a habitatului medieval timpuriu de pe Valea Mureșului. Locuințele și cuptoarele de la Tărtăria, punct Pietroșița, în vol. ArheoVest III.1: Interdisciplinarity in Archaeology and History, In Memoriam Florin Medeleț, 2015, JATEPress Kiadó, Szeged, p. 495-508

E. Dumitrașcu, S. Ene, M. Streinu, Cercetări arheologice preventive pe traseul autostrăzii A1 (Sibiu-Orăștie): locuirea medievală din punctul km 15+550 (com. Săliște, jud. Alba), CA, XXII, 2015, p. 41-64

I.V. Ferencz, C.C. Roman, Un complex La Tène descoperit la Tărtăria, Sargetia, s.n. VI (XLII), 2015, p. 155-167

M. Jevtić, Basarabi and Ferigile Finds on the Border Between the Carpathian Basin and Central Balkans. Contribution to the Early Iron Age Chronology, în S. Berecki (ed.), Iron Age Chronology in the Carpathian Basin. Proceedings of the International Colloquium from Târgu Mureș (8-10 October 2015), Editura Mega, Cluj-Napoca, 2016, p. 9-18

S.A. Luca, Tărtăria Rediviva, Bibliotheca Brukenthal LXXI, Editura Muzeului Național Brukental / Editura altip, Alba Iulia, 2016

P. Medović, I. Medović, GRADINA NA BOSUTU - naselje starijeg gvozdenog doba / GRADINA NA BOSUTU - Besiedlung der alteren Eisenzeit, Novi Sad 2010 (2011)

C.I. Popa, M. Simina, Cercetări arheologice la Lancrăm-Glod, Editura Ulise, Alba Iulia, 2004

O.C. Rogozea, Un semi-bordei atribuit fazei A3 a culturii Vinča descoperit la Tărtăria (com. Săliște, jud. Alba), în vol. ArheoVest IV.1: Interdisciplinarity in Archaeology and History, In Honorem Adrian Bejan, 2016, JATEPress Kiadó, Szeged, p. 121-161

O.C. Rogozea, D. Micle, R. Dincă, Materiale atribuite culturilor Coțofeni și Noua descoperite în hotarul administrativ al localității Tărtăria (jud. Alba), în vol. ArheoVest Symposium: Interdisciplinarity in Archaeology and History, Fifth edition: In Honorem Prof. Univ. Emerit Doinea Benea, 2017, JATEPress Kiadó, Szeged, p. 233-245

G. Rustoiu, O aşezare preistorică inedită identificată pe teritoriul municipiului Alba Iulia, Buletinul Cercurilor Științifice Studențești. Arheologie - Muzeologie - Istorie, 5, 1999, p. 95-105

\section{LISTA ILUSTRAȚIEI}

PI. I. 1. Localizarea zonei cercetate (I) (suport grafic OpenCycleMap și QuntumGIS). 2. Suprafața cercetată arheologic în campania preventivă din anul 2012 și principalele descoperiri (fundal, ortofotoplan 2004 / 2005)

PI. II. Localizarea zonei cercetate (II). 1. Suport grafic Bing Aerial (2012); 2. Suprafața cercetată arheologic în campania preventivă din anul 2012 și principalele descoperiri arheologice

PI. III. Localizarea zonei cercetate (III) - hărți și imagini de arhivă. 1. Zona sitului arheologic pe „Planurile Directoare de Tragere", foaia 2860, reprodusă în anul 1924 de pe harta austriacă 1:25.000 (sursa: geospatial.org); 2. Imagine satelitară efectuată de SUA în 17.08.1968 și declasificată la 01.01 .1995 (sursa: http://earthexplorere.usgs.gov, cod DS1104-2155DA015); 3. Extras din „Harta Topografică 1:25.000”, foaia L34-XXIV (anii '90)

PI. IV. Noi descoperiri arheologice în zona administrativă a localității Tărtăria (2012-2017)

PI. V. Modificarea cadrului natural și impactul asupra vestigiilor arheologice (imagine satelitară 2016 furnizată de platforma Google Earth). „Epicentrul” este reprezentat de „Borna 01” din cadrul sitului, stabilită în toamna anului 2016.

PI. VI. Interpretarea preliminară a prospectărilor geomagnetice din anul 2014

PI. VII. Corelarea preliminară a prospectărilor geomagnetice din anul 2014 cu rezultatele campaniei preventive din 2012

PI. VIII. Zona de est a sitului și elemente de infrastructură actuale. Imagini generale realizate din dronă la începutul lunii octombrie 2016 
PI. IX. Zona de vest a sitului. Imagini generale efectuate din dronă la începutul lunii octombrie 2016

PI. X. Amplasarea unităților de cercetare din campania 2016 (imagini generale realizate din dronă la finalul lunii octombrie). Arheologia peisajului (?) - zonă afectată și modificată ireversibil. Suprafața cuprinsă în interiorul liniei albastre punctate reprezintă în procent de 95\% suprafața sitului arheologic Tărtăria - Podu Tărtăriei vest, cod RAN 7080.03. In ce măsură mai putem vorbi despre conservarea patrimoniului pentru generațiile următoare?

PI. XI. Amplasarea unităţilor de cercetare în funcție de rezultatele măsurătorilor magnetometrice: $\mathbf{1}$. suprapunerea anomaliilor (2014) peste fotografia georeferențiată din dronă (toamna 2016); 2. conturul anomaliilor (2014) și complexele arheologice cercetate în campania 2016; 3. zona de interes, în raport cu celelalte zone prospectate magnetometric.

PI. XII. Unitățile de cercetare și complexele arheologice descoperite în campania 2016 (stânga - fotografie din dronă georeferențiată; dreapta - grundurile complexelor digitizate pe baza desenelor tehnice și a ridicărilor topografice)

Pl. XIII. Zone propuse pentru realizarea de prospectări geomagnetice în campania 2017

PI. XIV. Imagini din dronă asupra zonei sitului - august 2017 (I). 1. Vedere spre est; 2. Vedere spre sud

PI. XV. Imagini din dronă asupra zonei sitului - august 2017 (II). Vedere spre nord-vest

PI. XVI. Amplasarea unităților de cercetare din campania 2016 (roșu) şi campania 2017 (galben)

PI. XVII. Amplasarea unităţilor de cercetare în funcție de rezultatele prospectărilor geomagnetice: $\mathbf{1}$. suprapunerea anomaliilor (2014) peste fotografii georeferențiate din dronă (2016 \& 2017); 2. conturul anomaliilor (2014) și complexele arheologice cercetate în campaniile 2016 (roșu) şi 2017 (albastru); 3. zona de interes, în raport cu celelalte zone prospectate magnetometric

PI. XVIII. Unităţile de cercetare şi complexele arheologice descoperite în campania 2017 (stânga - fotografie georeferențiată din dronă; dreapta - grundurile complexelor, digitizate pe baza desenelor tehnice și a ridicărilor topografice, roșu - campania 2016, galben - campania 2017)

PI. XIX. Zona săpăturii și puncte de aglomerare a materialului ceramic în arătură observate cu prilejul perieghezelor (2016 \& 2017)

PI. XX. Prospectări geomagnetice preliminare (2014-2017)

PI. XXI. 1-4. Aspecte din timpul cercetărilor (august 2017)

PI. XXII. S032 - profil magistral de vest

PI. XXIII. S034 - profil magistral de vest

PI. XXIV. Cx 259: 1-6. Imagini din timpul cercetării complexului (campania 2016)

PI. XXV. Cx 259: 1-2, 4-5. Imagini din timpul cercetării complexului (campania 2017); 3. Grund și profil

PI. XXVI. Cx 261: 1-2, 4-5. Imagini din timpul cercetării complexului; 3. Grund și profil

PI. XXVII. Cx 262-263: 1. Grund și profil; 2-4. Imagini din timpul cercetării complexelor

PI. XXVIII. CX 263: 1-5. Imagini din timpul cercetării complexului

Pl. XXIX. 1-3. Cx 268, imagini din timpul cercetării complexului; 4. Cx 264 (dreapta) şi Cx 268 (stânga), grund și profil; 5-6. Cx 264, imagini din timpul cercetării complexului

Pl. XXX. Cx 265 (dreapta) şi Cx 266 (stânga), grund și profil

PI. XXXI. 1-3. Cx 266, imagini din timpul cercetării complexului; 4. Imagini de ansamblu Cx 265 (dreapta) și Cx 266 (stânga); 5-8. Cx 265, imagini din timpul cercetării complexului

PI. XXXII. Cx 263: strachină decorată în stil Basarabi, în curs de restaurare

PI. XXXIII. Vase în curs de restaurare: 1. Cx 266; 2. Cx 263; 3. Cx 260

PI. XXXIV. 1-3. Cx 267: Fragmente ceramice aparținând culturii Coțofeni; 4-6. Cx 265: Fragmente lipitură de perete impregnate cu fragmente ceramice decorate în stil Basarabi

PI. XXXV. 1. Cx 259 B: Lamă cuțit din fier fragmentară; 2-3. Cx 266: Râșniţă fragmentară

Pl. XXXVI. Cx 269: 1. Grund și profil; 2-4. Imagini din timpul cercetării complexului; 5. Cx 267, imagine din timpul cercetării complexului

PI. XXXVII. CX 270: 1. Grund și profil; 2-6. Imagini din timpul cercetării complexului

PI. XXXVIII. Cx 271 și Cx 274: 1. Grund și profil; 2-3. Imagini din timpul cercetării complexelor

PI. XXXIX. Cx 271 și Cx 274: 1-7. Imagini din timpul cercetării complexelor

PI. XL. Cx 272: 1. Grund și profil; 2-5. Imagini din timpul cercetării complexului

PI. XLI. Cx 273: 1. Grund și profil; 2-5. Imagini din timpul cercetării complexului

Pl. XLII. Vase întregibile (selectiv): 1-2. Cx 259; 3-4. Cx 272

PI. XLIII. Vase întregibile (selectiv): 1-2. Cx 274; 3. Cx 263

PI. XLIV. 1-3. Fragmente ceramice cu decor tipic Basarabi descoperite în campania 2017

Pl. XLV. 1-6. Fragmente ceramice cu decor tipic Basarabi descoperite în campania 2017

PI. XLVI. 1-6. Material special (2017): 1. Lamă din fier (Cx 259); 2. Topor miniatural din piatră reutilizat ca pandantiv (?) (Cx 271); 3. Nucleu mic de obsidian (din stratul de cultură); 4. Vatră portabilă, imagine in situ înainte de prelevare (Cx 273); 5. Fragment de brățară din bronz (din stratul de cultură); 6. Ac de păr din bronz cu capătul în formă de „, 8 " (din stratul de cultură) 
PI. XLVII. 1-4. Imagini din timpul prelevării probelor pentru studiul de bioarheologie

PI. XLVIII. Material ceramic tipic stilului Basarabi (faza timpurie) - fotografii

PI. XLIX. Material ceramic tipic stilului Basarabi (faza timpurie) - desene (1)

Pl. L. Material ceramic tipic stilului Basarabi (faza timpurie) - desene (2)

\section{LIST OF ILLUSTRATION}

PI. I. 1. Location of the investigated area (I) (graphic support OpenCycleMap and QuntumGIS). 2. The area investigated by preventive archaeological excavations in 2012 and the main finds (background: orthophotomap 2004 / 2005)

Pl. II. Location of the investigated area (II). 1. Graphic support Bing Aerial (2012); 2. The area investigated by preventive archaeological excavations in 2012 and the main finds

PI. III. Location of the investigated area (III) - archive maps and images. 1. The area of the archaeological site on the „Planurile Directoare de Tragere”, sheet 2860, reproduced in year 1924 on the historic Austrian map 1:25.000 (source: geo-spatial.org); 2. Sattelite image made by USA on 17.08.1968 and declassified on 01.01.1995 (source: http://earthexplorere.usgs.gov, code DS1104-2155DA015); 3. Excerpt of the „Topographic Map 1:25.000", sheet L-34-XXIV (years '90)

PI. IV. New archaeological discoveries within the administrative limits of the Tărtăria locality (2012-2017)

Pl. V. Change of the natural environment and the impact on the archaeological vestiges (sattelite image 2016 provided by the Google Earth platform). The „epicentre” is represented by the de „Milestone 01” within the site, set in autumn 2016.

PI. VI. Preliminary interpretation of the geomagnetic prospections of 2014

PI. VII. Preliminary correlation of the geomagnetic prospections of 2014 with the results of the results of the 2012 preventive campaign

PI. VIII. The East zone of the site and contemporary elements of infrastructure. General images made by drone at the beginning of October 2016

PI. IX. The West zone of the site. General images made by drone at the beginning of October 2016

PI. X. The location of the archaeological research units in 2016 (images made by drone at the beginning of Octorber 2016). Landscape archaeology (?) - area impacted and irreversibly transformed. The surface outlined within the blue line represents about 95\% Tărtăria - Podu Tărtăriei vest archaeological site (RAN code 7080.03). To what degree one can speak about heritage conservation for future generations?

PI. XI. The location of the archaeological excavations unit based on the results of the geomagnetic prospections: 1. overlapping anomalies (2014) over the georeferenced photo by drone (autumn 2016); 2 . The outline of the anomalies (2014) and the archaeological features investigated in 2016; 3. The area of interest, compared with the other areas investigated by geomagnetic prospections

PI. XII. The archaeological excavation units and the features discovered during the 2016 campaign (left georeferenced photo made by drone; right - grundriss drawings of the archaeological features digitised based on the technical drawings and the topographic surveys)

PI. XIII. The zones proposed for making geomagnetic prospections in 2017

Pl. XIV. Images of the site made by drone - August 2017 (I). 1. View from East; 2. View from South

PI. XV. Images of the site made by drone - August 2017 (II). View from North-West

PI. XVI. The location of the archaeological excavation units in 2016 (red) and 2017 (yellow)

PI. XVII. The location of the archaeological excavations units based on the results of the geomagnetic prospections: 1. overlapping anomalies (2014) over the georeferenced photo by drone (2016 \& 2017); 2. The outline of the anomalies (2014) and the archaeological features investigated in 2016 (red) and 2017 (yellow); 3. The area of interest, compared with the other areas investigated by geomagnetic prospections

PI. XVIII. The archaeological excavations units and the archaeological features discovered in 2017 (left georeferenced photo made by drone; right - grundriss drawings of the archaeological features digitised based on the technical drawings and the topographic surveys, red - 2016 campaign, yellow -2017 campaign)

PI. XIX. The area of the archaeological excavations and spot of agglomeration with archaeological material in the plough land observed during the fieldwalkings (2016 \& 2017)

PI. XX. Preliminary geomagnetic prospections (2014-2017)

PI. XXI. 1-4. Images during the archaeological excavations (august 2017)

PI. XXII. S032 - Main West cross-section

PI. XXIII. S034 - Main West cross-section

PI. XXIV. Cx 259: 1-6. Images during the archaeological feature's excavation (campaign 2016)

PI. XXV. Cx 259: 1-2, 4-5. Images during the archaeological feature's excavation (campaign 2017); 3. Grundriss and cross section

PI. XXVI. Cx 261: 1-2, 4-5. Images during the archaeological feature's excavation; 3. Grundriss and cross section 
PI. XXVII. Cx 262-263: 1. Grundriss and cross-section; 2-4. Images during the archaeological features' excavation

PI. XXVIII. CX 263: 1-5. Images during the archaeological feature's excavation

PI. XXIX. 1-3. Cx 268, images during the archaeological feature's excavation; 4. Cx 264 (right) and Cx 268 (left), Grundriss and cross section; 5-6. Cx 264, images during the archaeological feature's excavation

PI. XXX. Cx 265 (right) and Cx 266 (left), Grundriss and cross section

PI. XXXI. 1-3. Cx 266, images during the archaeological feature's excavation; 4. General views Cx 265 (right) and Cx 266 (left); 5-8. Cx 265, images during the archaeological feature's excavation

PI. XXXII. Cx 263: bowl decorated in the Basarabi style (under restoration)

PI. XXXIII. Pottery under restoration: 1. Cx 266; 2. Cx 263; 3. Cx 260

PI. XXXIV. 1-3. Cx 267: Pottery sherds pertaining to the Coțofeni culture; 4-6. Cx 265: Fragments of wall plaster with impressions of pottery sherds decorated in the Basarabi style

Pl. XXXV. 1. Cx 259 B: Fragmentary iron knife blade; 2-3. Cx 266: Fragmentary grinders

PI. XXXVI. CX 269: 1. Grundriss and cross-section; 2-4. Images during the archaeological feature's excavation; 5. Cx 267, image during the archaeological feature's excavation

PI. XXXVII. CX 270: 1. Grundriss and cross-section; 2-6. Images during the archaeological feature's excavation

PI. XXXVIII. Cx 271 și Cx 274: 1. Grundriss and cross-section; 2-3. Images during the archaeological feature's excavation

PI. XXXIX. Cx 271 și CX 274: 1-7. Images during the archaeological features' excavation

PI. XL. Cx 272: 1. Grundriss and cross-section; 2-5. Images during the archaeological feature's excavation

PI. XLI. Cx 273: 1. Grundriss and cross-section; 2-5. Images during the archaeological feature's excavation

PI. XLII. Entire vessels (selective): 1-2. Cx 259; 3-4. Cx 272

PI. XLIII. Entire vessels (selective): 1-2. Cx 274; 3. Cx 263

PI. XLIV. 1-3. Pottery fragments decorated in the Basarabi style discovered during 2016 campaign

PI. XLV. 1-6. Pottery fragments decorated in the Basarabi style discovered during 2017 campaign

PI. XLVI. 1-6. Special archaeological material (2017): 1. Iron blade (Cx 259) ; 2. Miniature stone axe used as pendant (?) (Cx 271); 3. Small obsidian nucleus (from the "culture layer"); 4. Portable hearth, in situ image (Cx 273); 5. Fragment of a bronze bracelet (from the "culture layer"); 6. Bronze hair pin with " 8 " shape endings (from the "culture layer")

PI. XLVII. 1-4. Images during taking samples for the bioarchaeology study

PI. XLVIII. Pottery characteristic for the Basarabi style (early phase) - photos

PI. XLIX. Pottery characteristic for the Basarabi style (early phase) - drawings (1)

Pl. L. Pottery characteristic for the Basarabi style (early phase) - drawings (2)

CORINA BORȘ,

Muzeul Naţional de Istorie a României, corina.bors73@gmail.com LUCIANA RUMEGA-IRIMUS,

Muzeul Național de Istorie a României (arheolog asociat) / Institutul de Arheologie „Vasile Pârvan” (doctorand) luciana_dr@yahoo.com VLAD RUMEGA-IRIMUȘ Muzeul Național de Istorie a României (arheolog asociat) / Universitatea „Valahia” (doctorand), vladrumega@gmail.com 

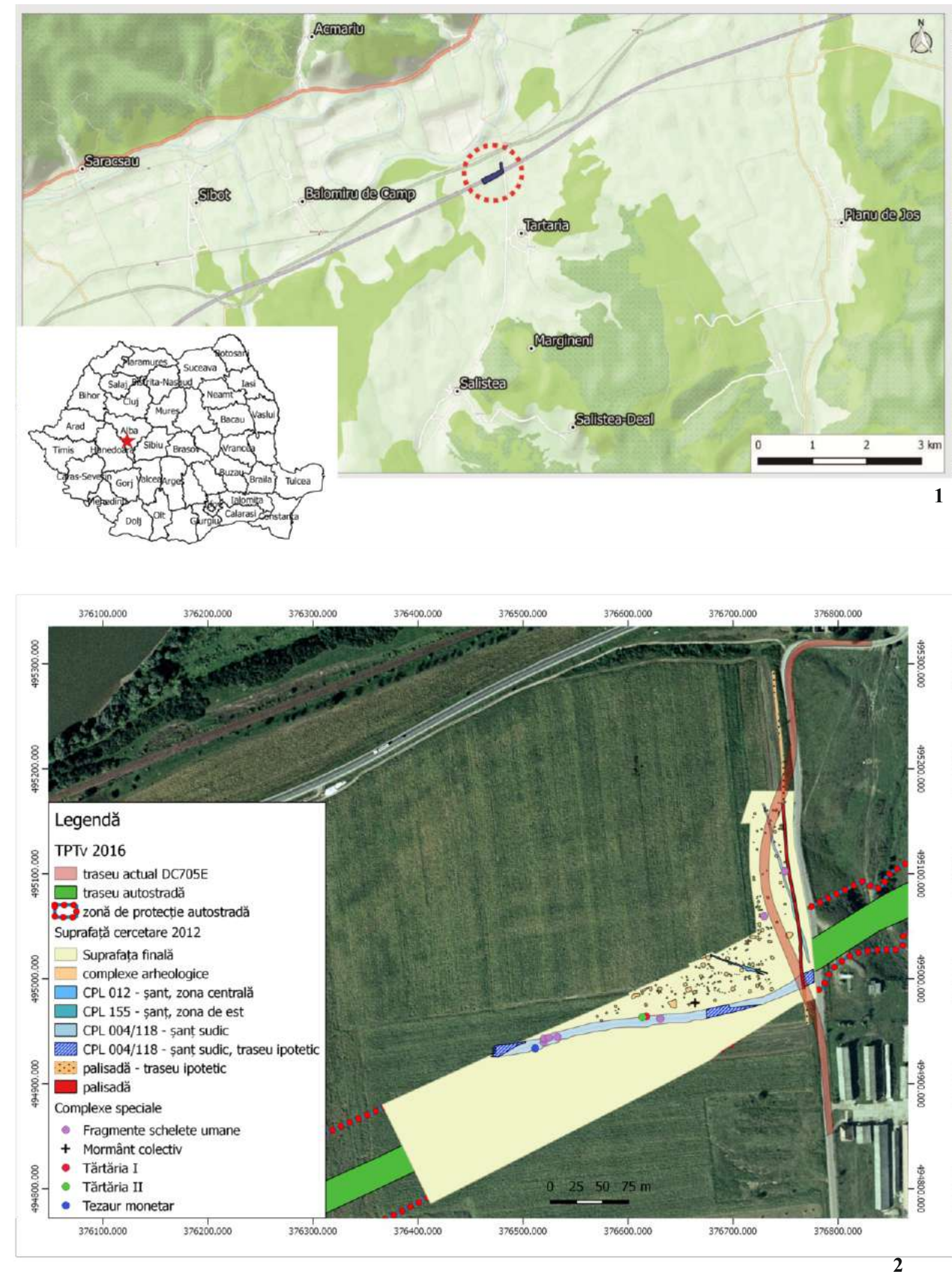

1. Localizarea zonei cercetate (I) (suport grafic OpenCycleMap și QuantumGIS). 2. Suprafața cercetată arheologic în campania preventivă din anul 2012 și principalele descoperiri (fundal, ortofotoplan 2004 / 2005) 

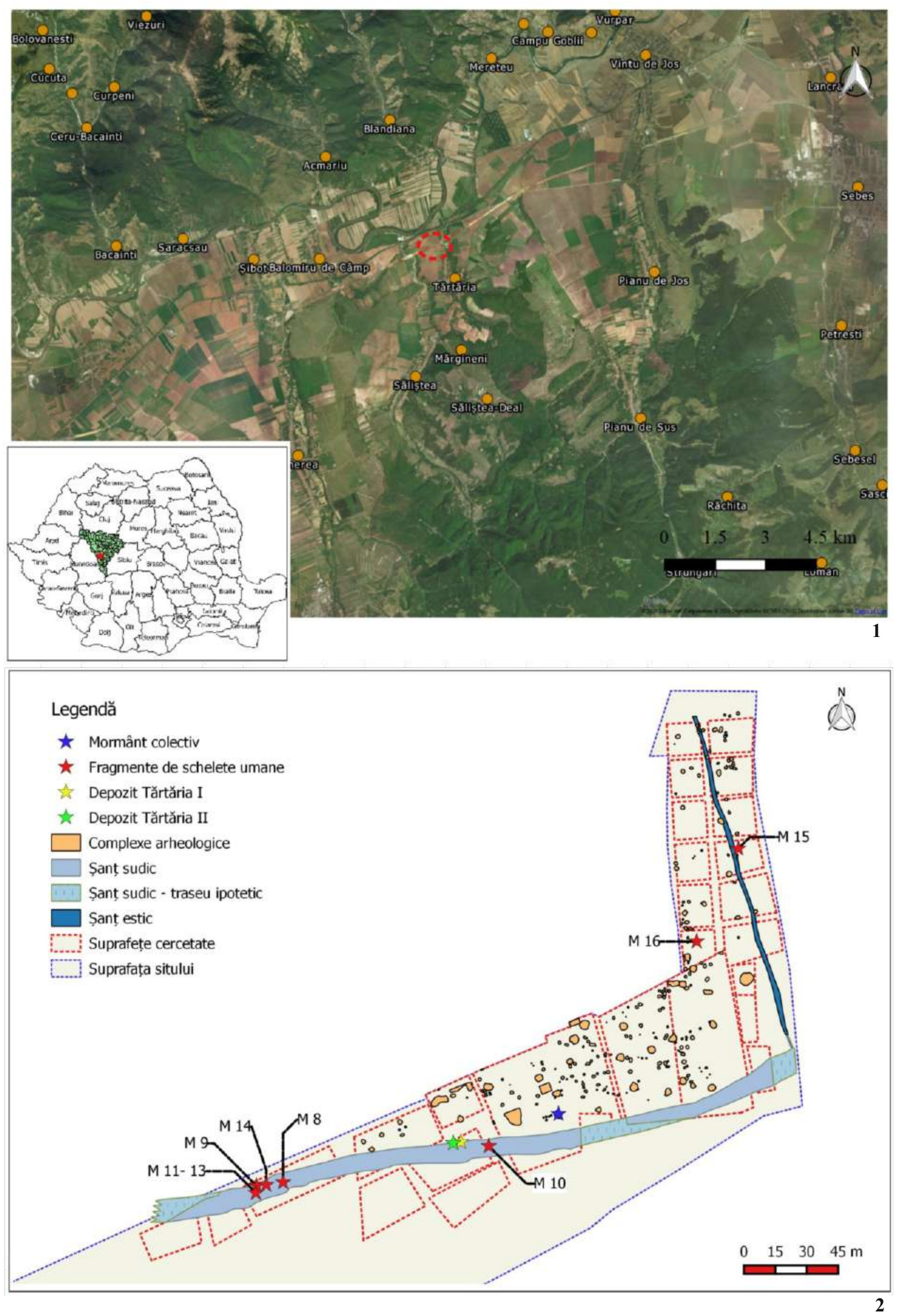

Localizarea zonei cercetate (II). 1. Suport grafic Bing Aerial (2012); 2. Suprafața cercetată arheologic în campania preventivă din anul 2012 și principalele descoperiri arheologice 

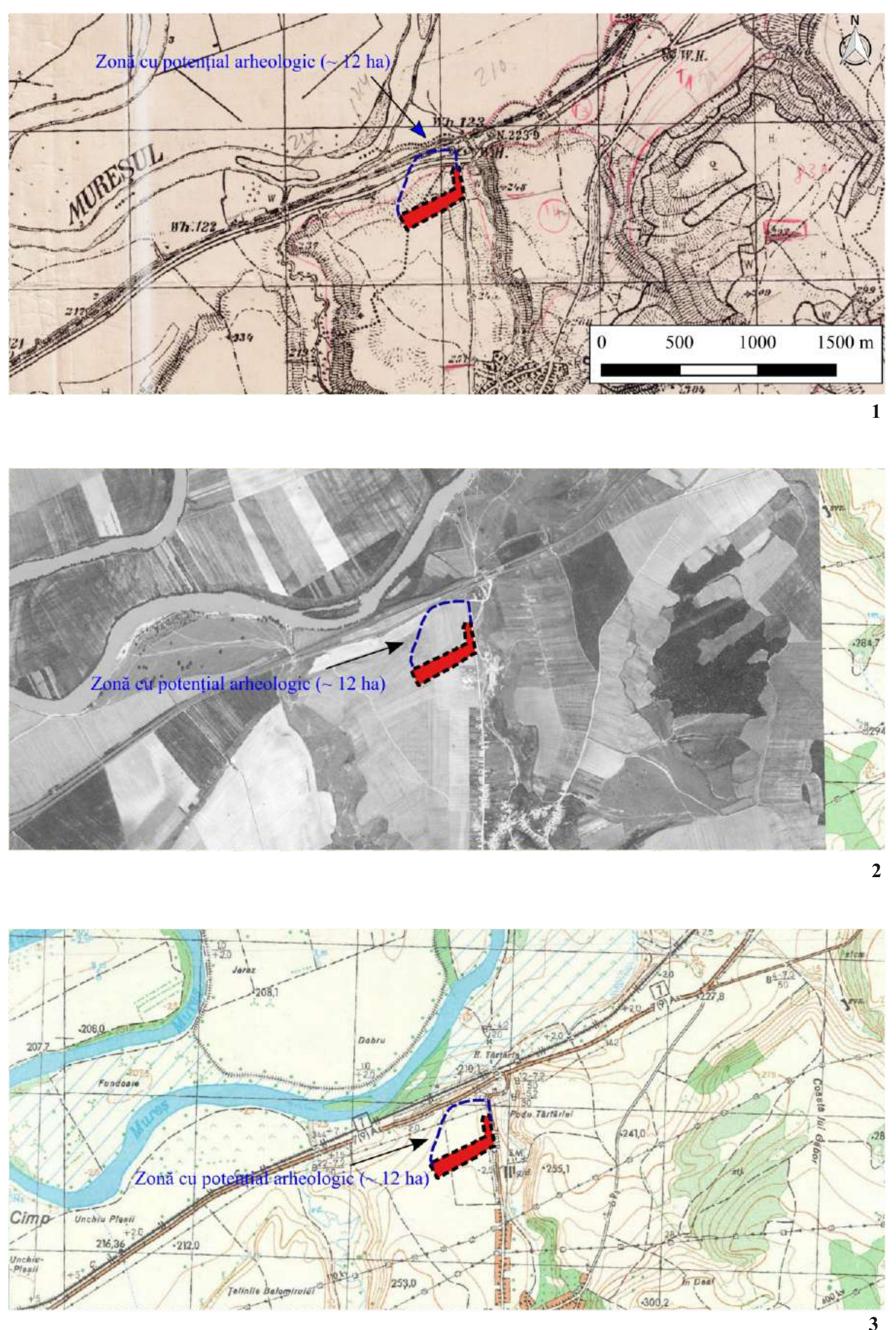

Localizarea zonei cercetate (III) - hărți și imagini de arhivă. 1. Zona sitului arheologic pe "Planurile Directoare de Tragere", foaia 2860, reprodusă în anul 1924 de pe harta austriacă 1:25.000 (sursa: geo-spatial.org); 2. Imagine satelitară efectuată de SUA în 17.08.1968 și declasificată la 01.01.1995 (sursa: http://earthexplorere.usgs.gov, cod DS1104-2155DA015); 3. Extras din „Harta Topografică 1:25.000”, foaia L-34-XXIV (anii '90) 


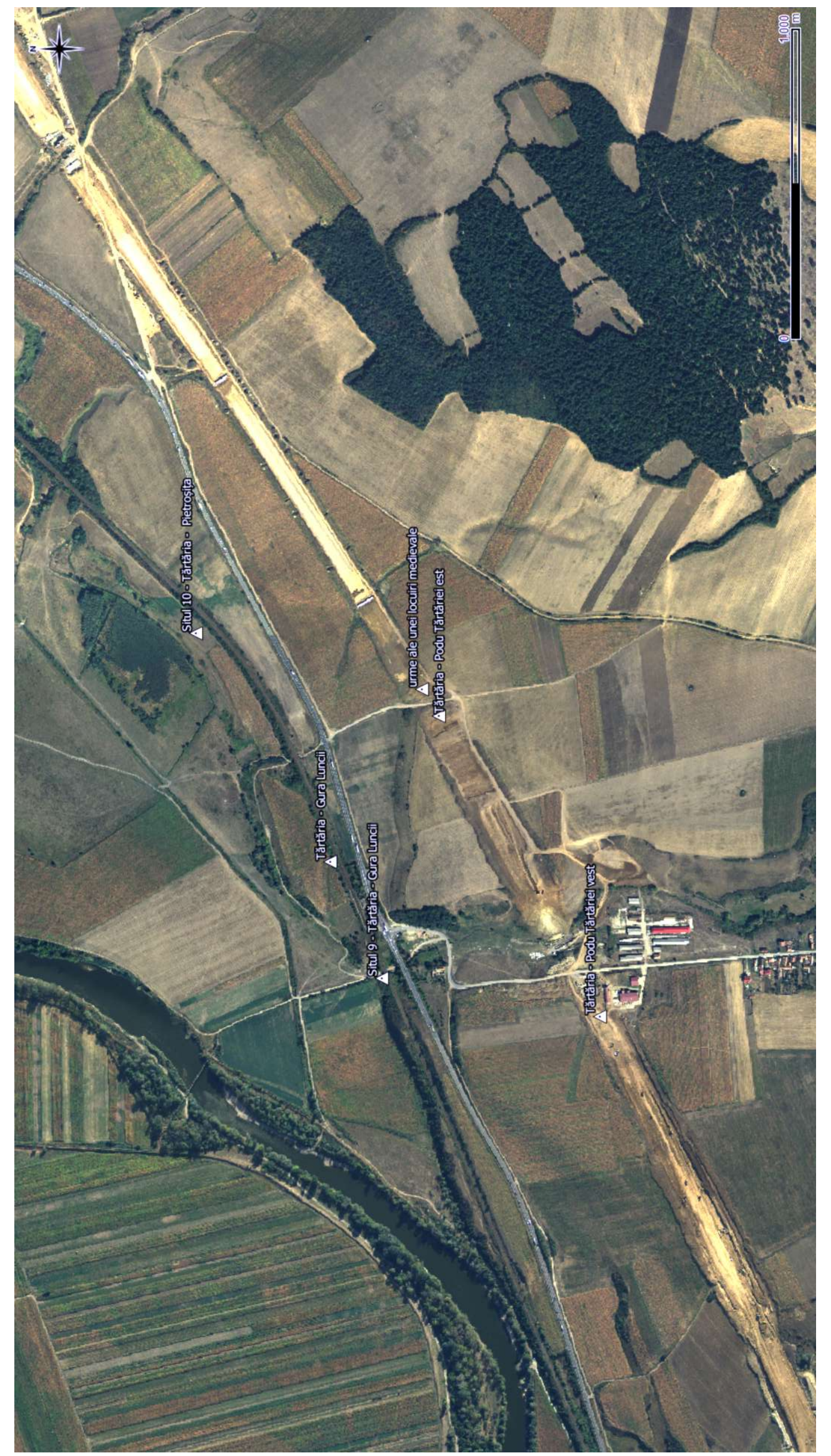

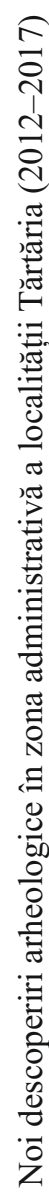

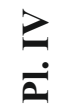




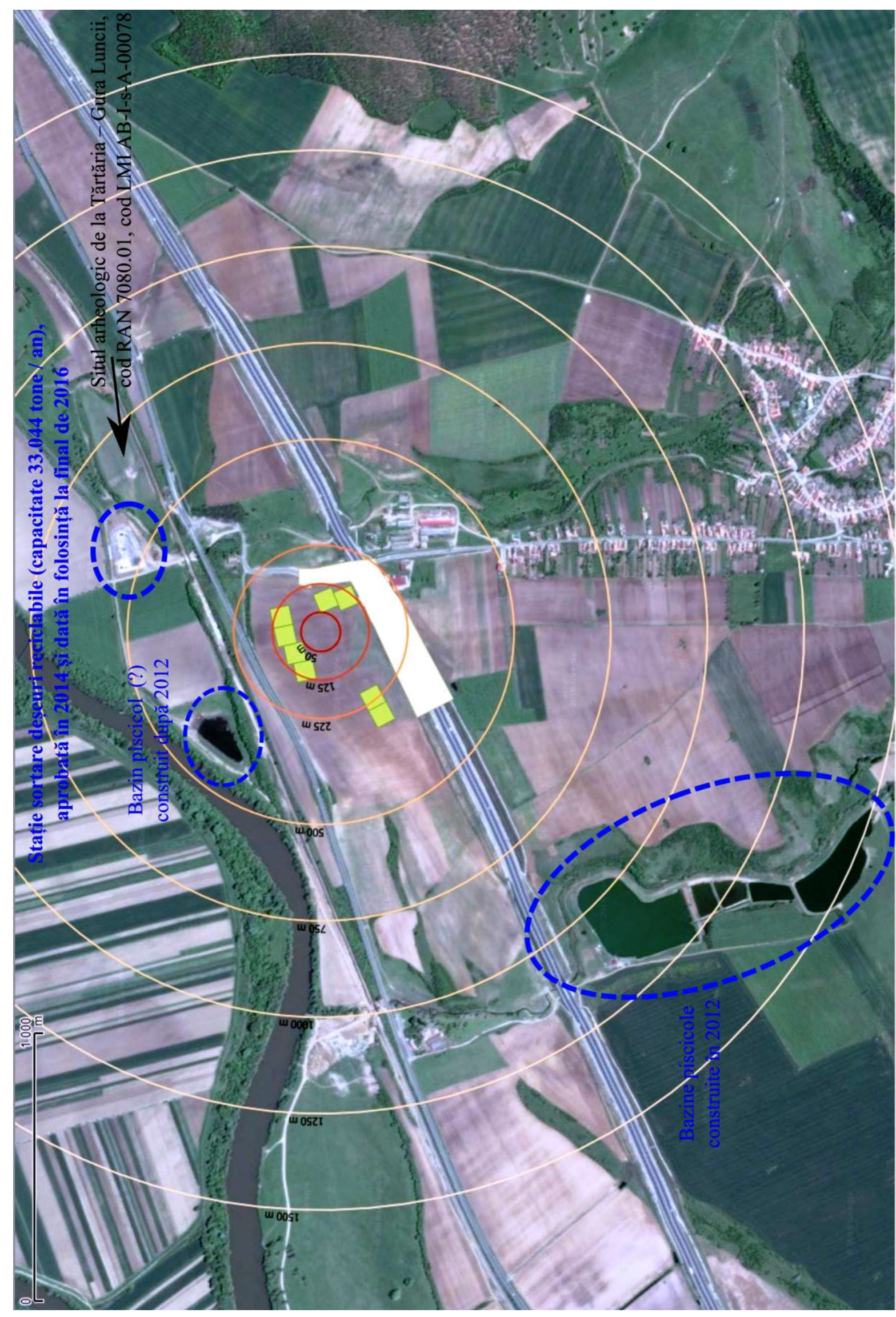

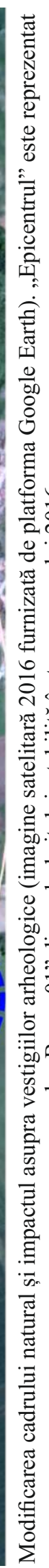




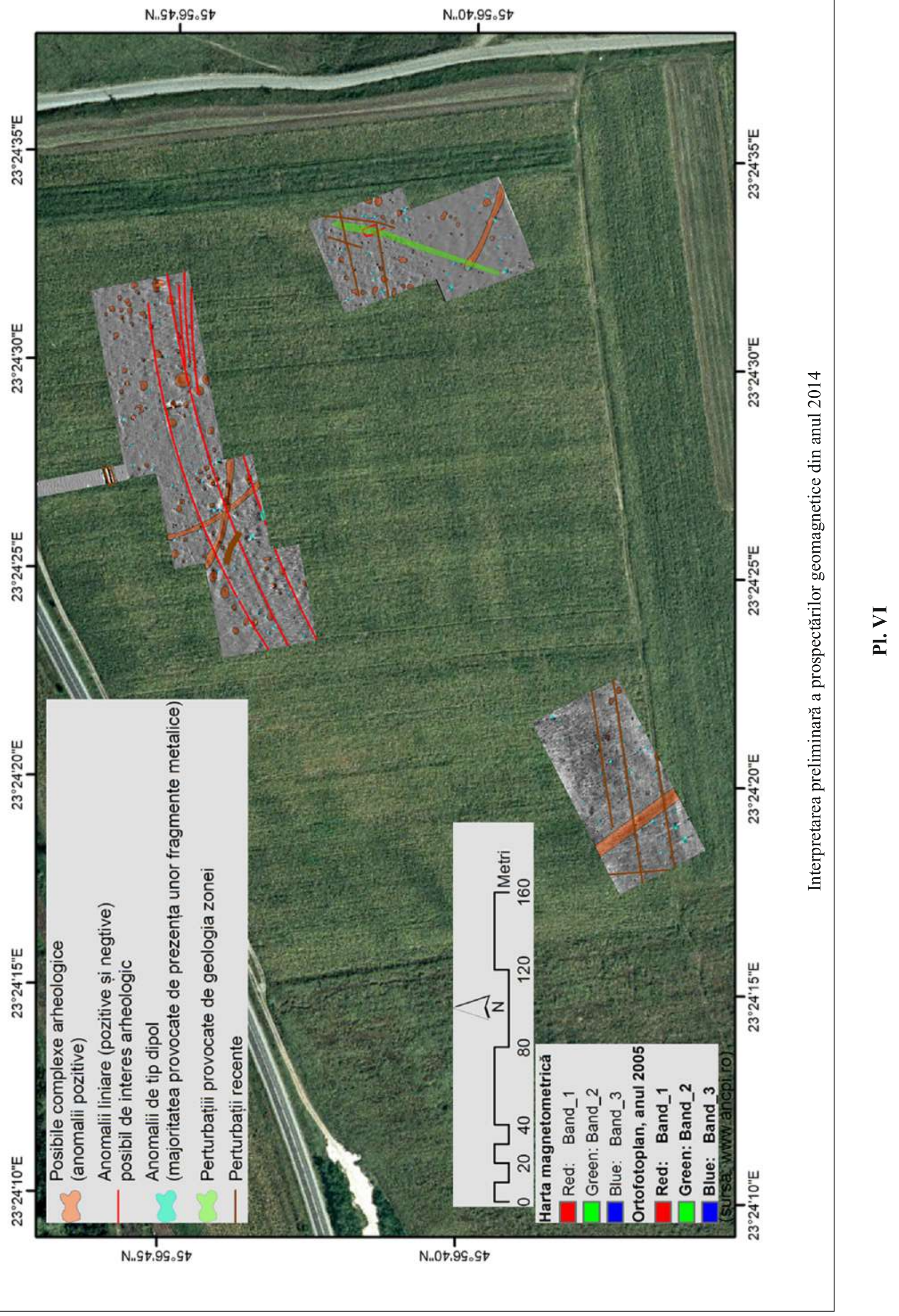




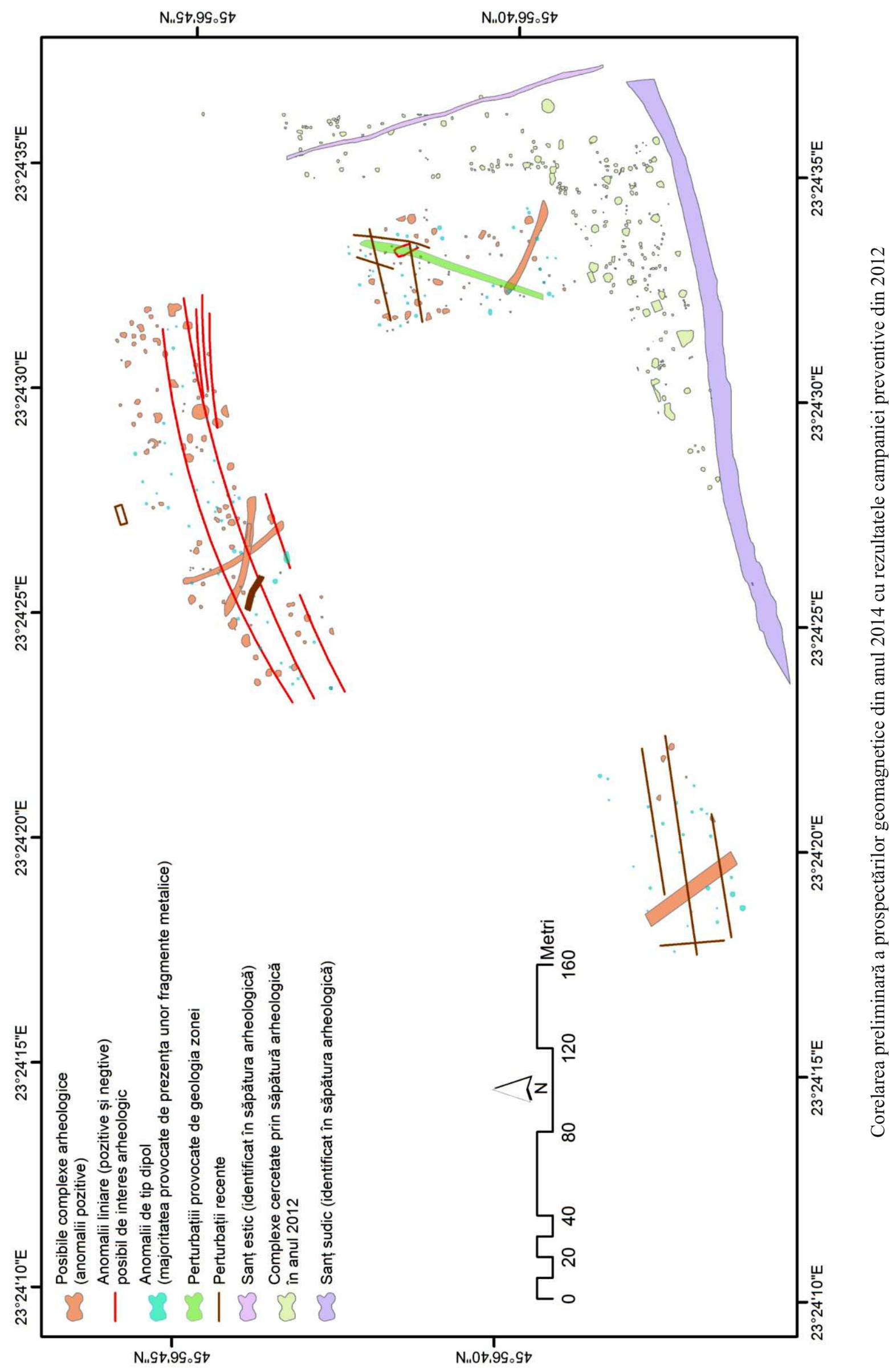

$\stackrel{7}{i}$ 


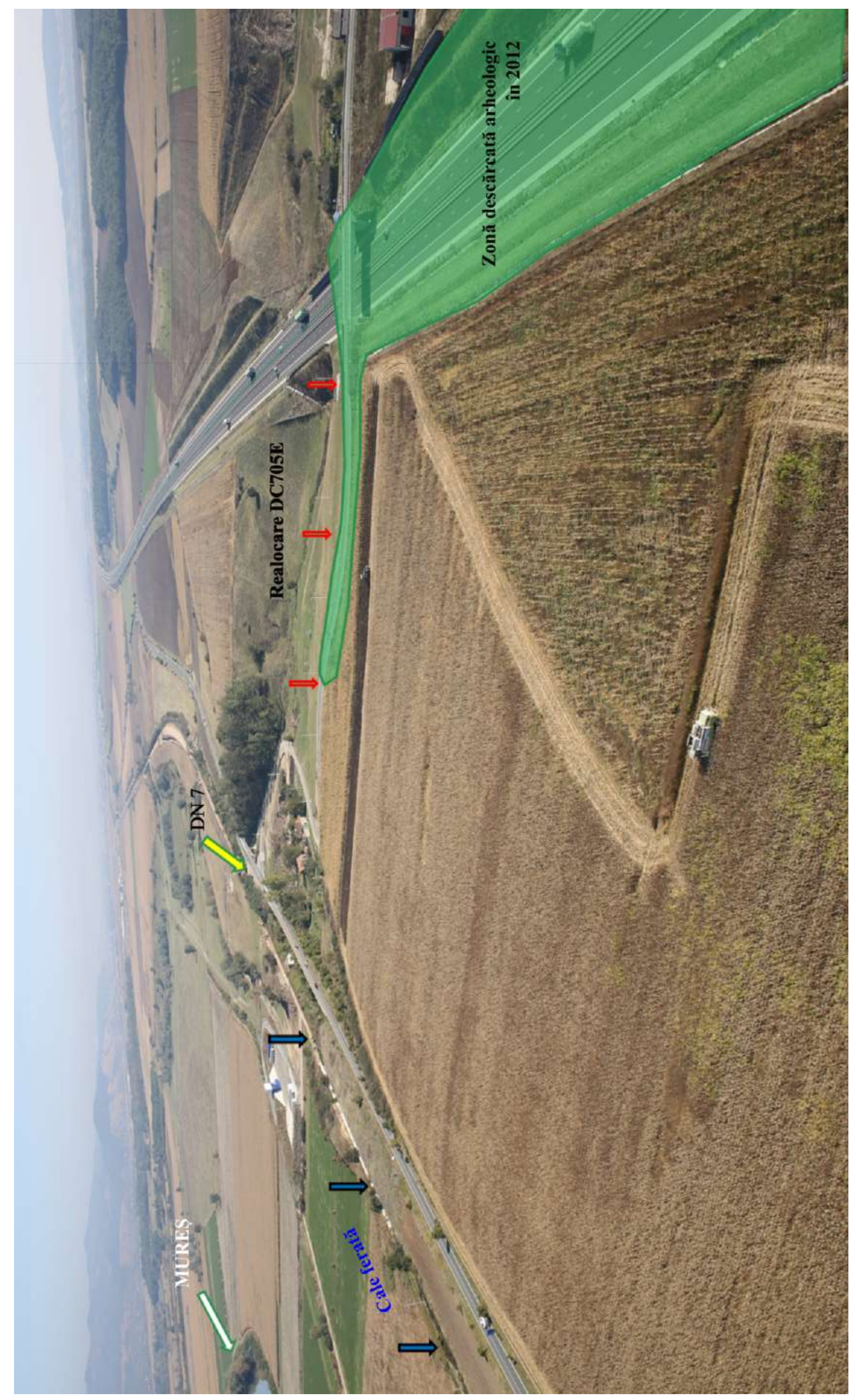

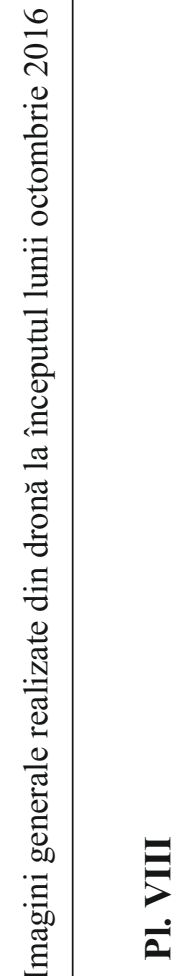




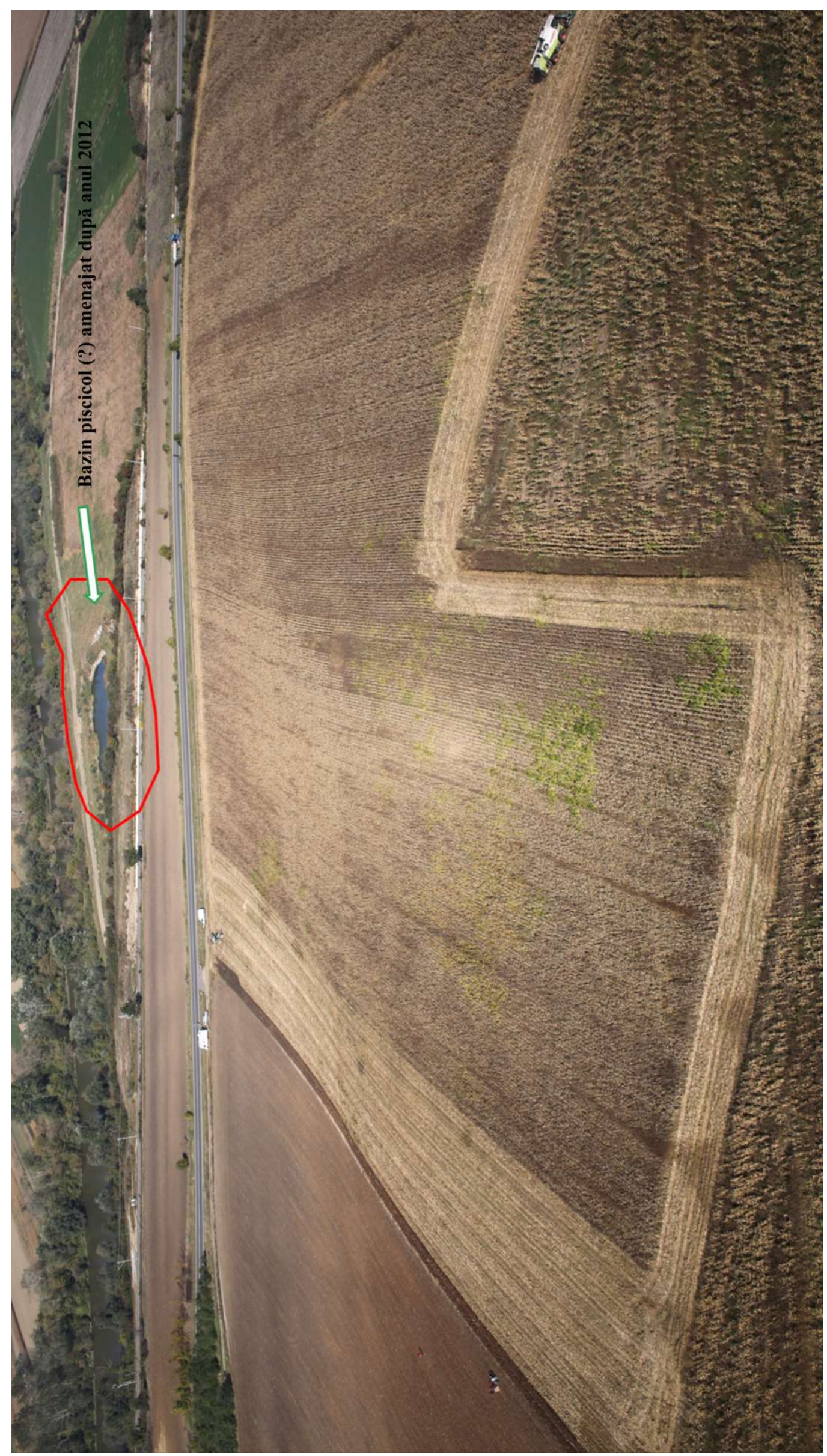

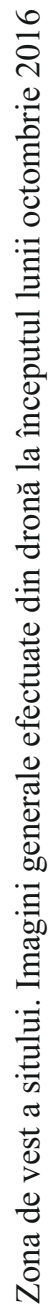




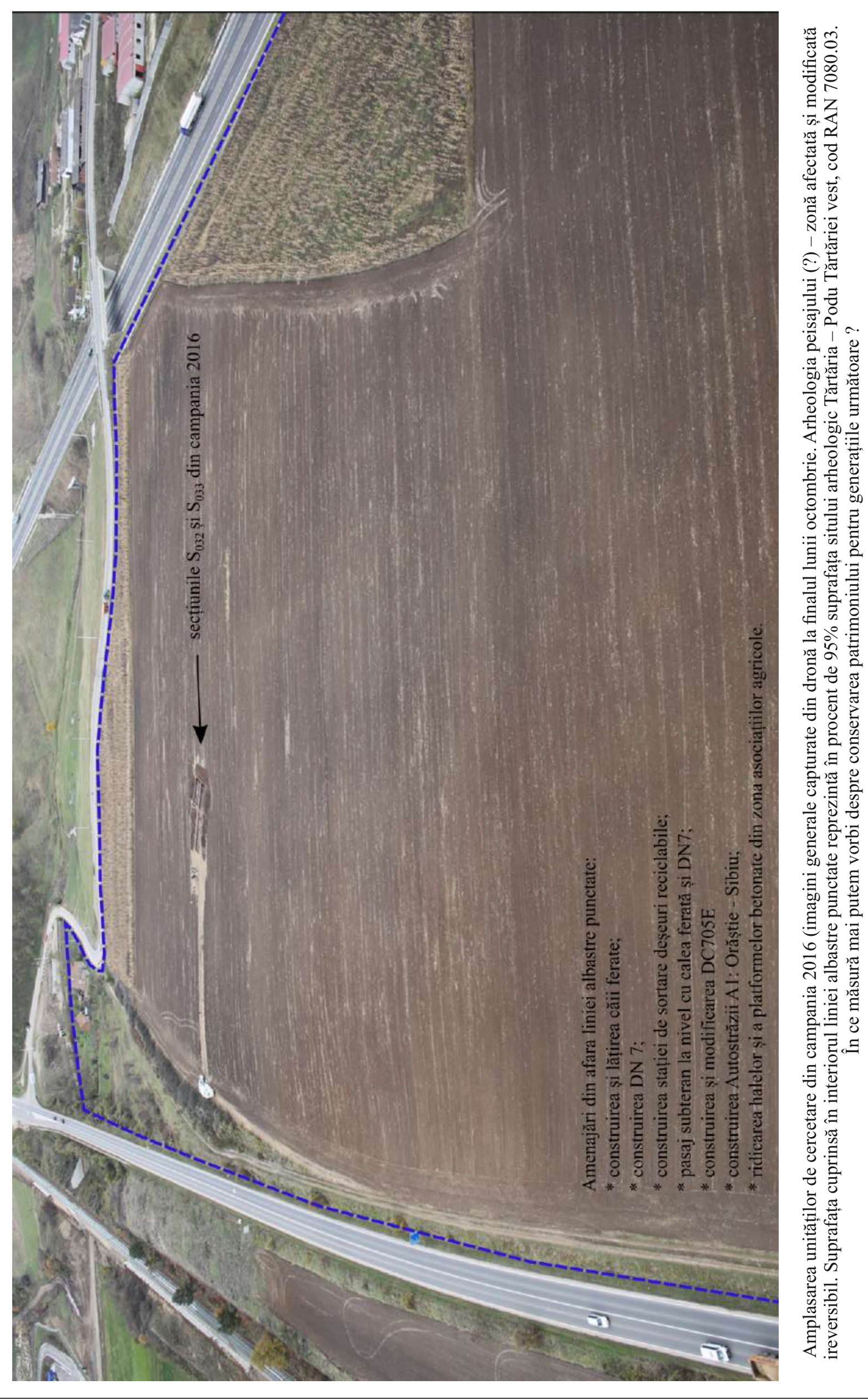



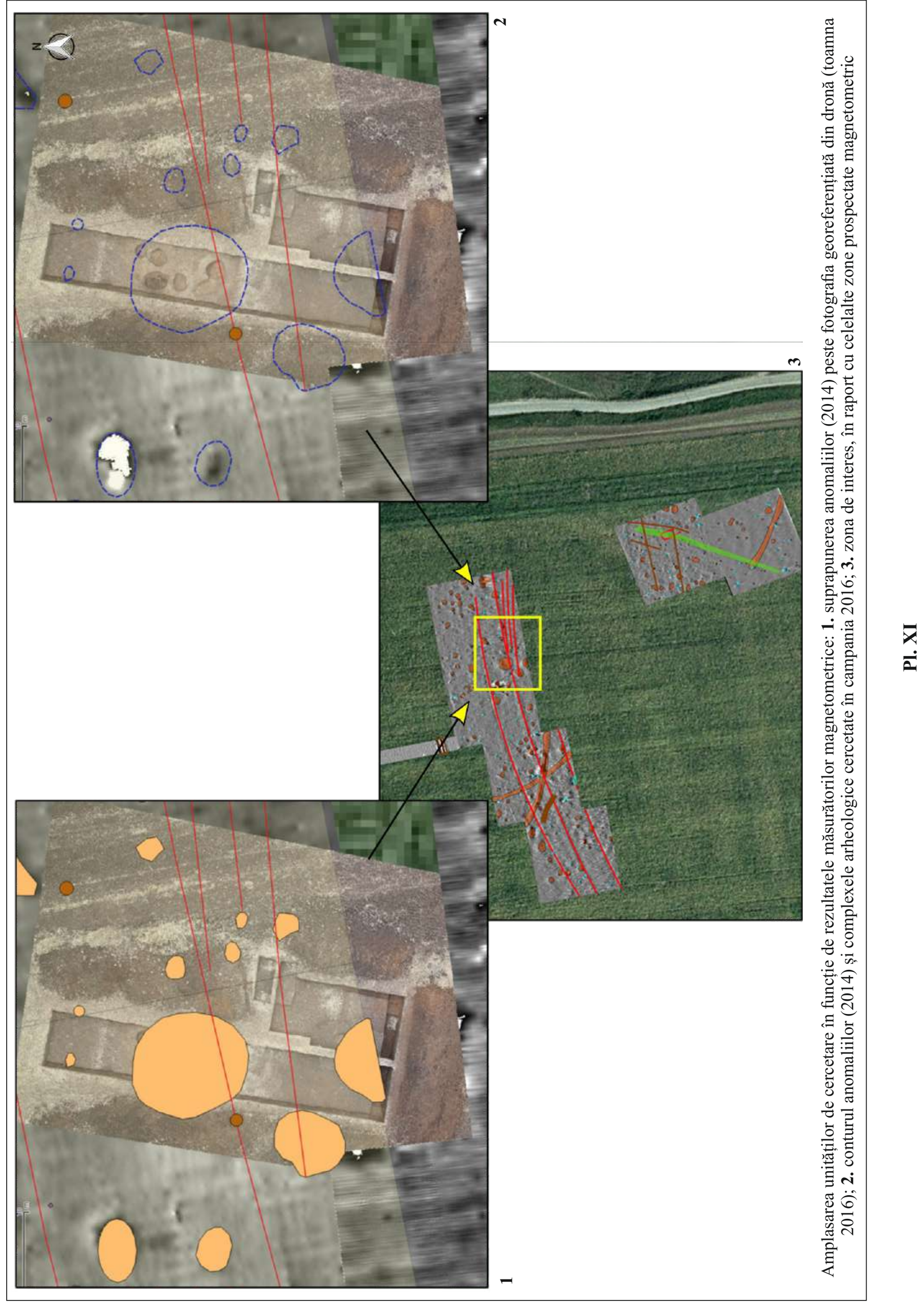

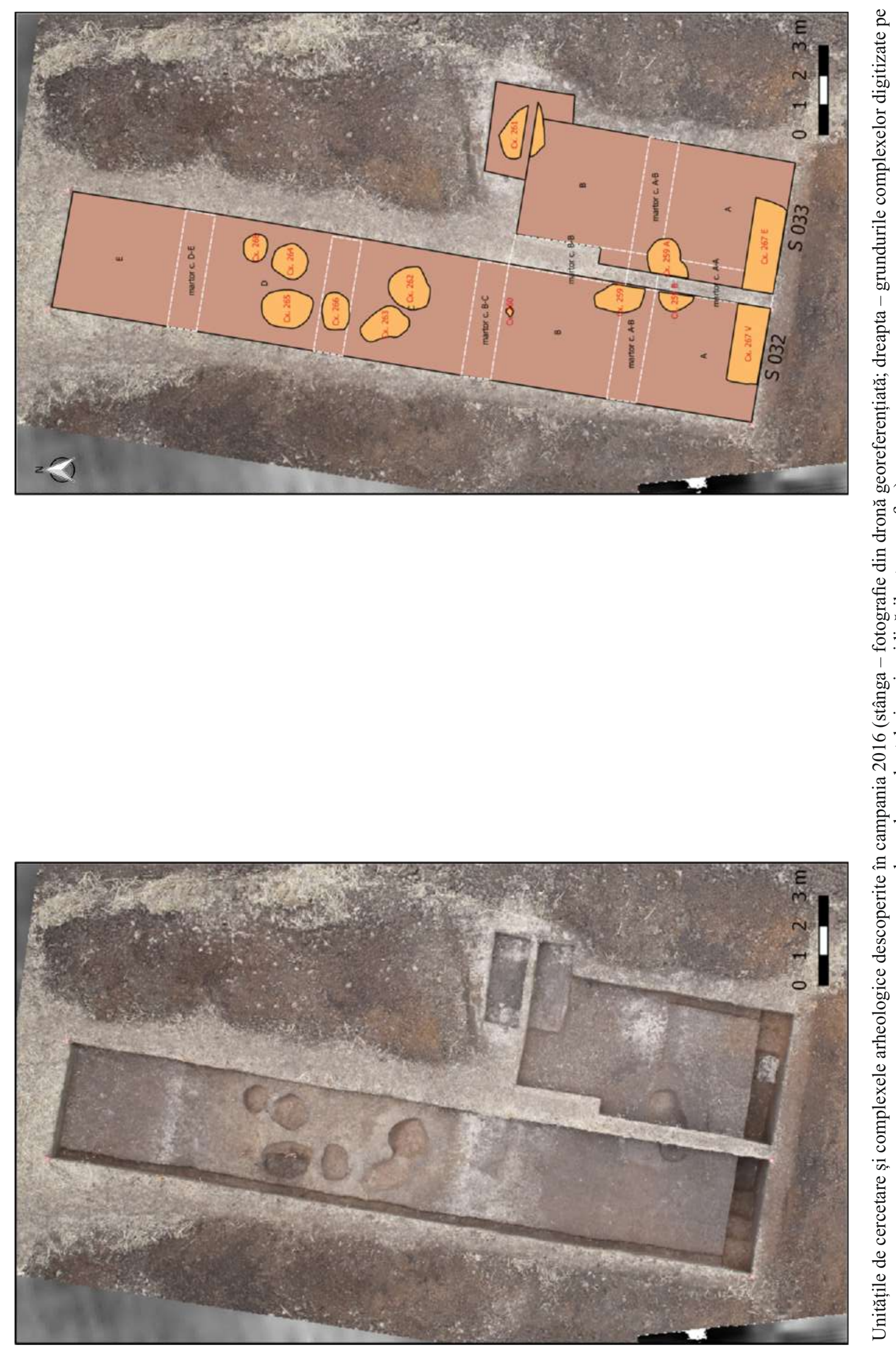


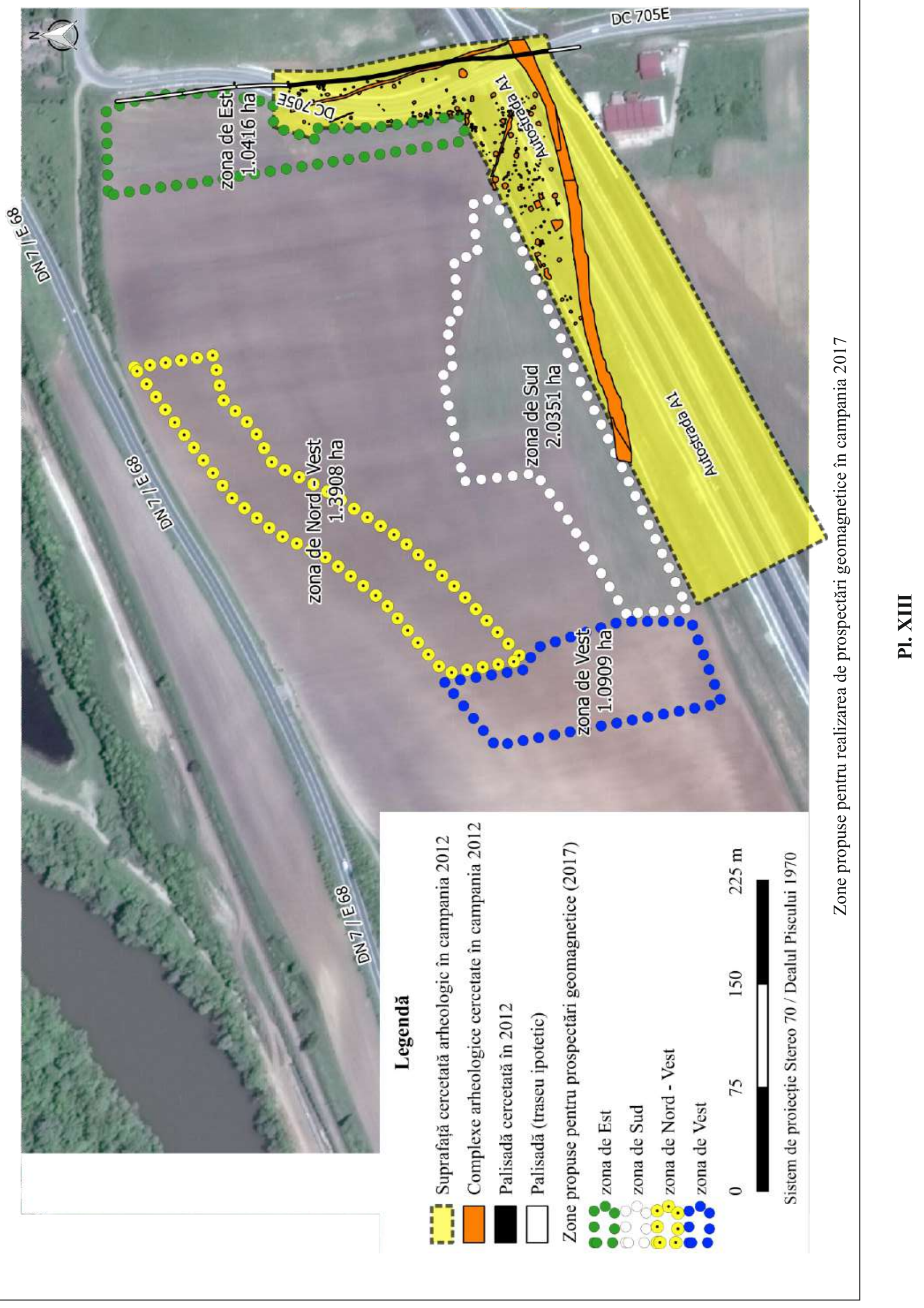


relocare DC 705E - zonă cercetată arheologic în campania 2012
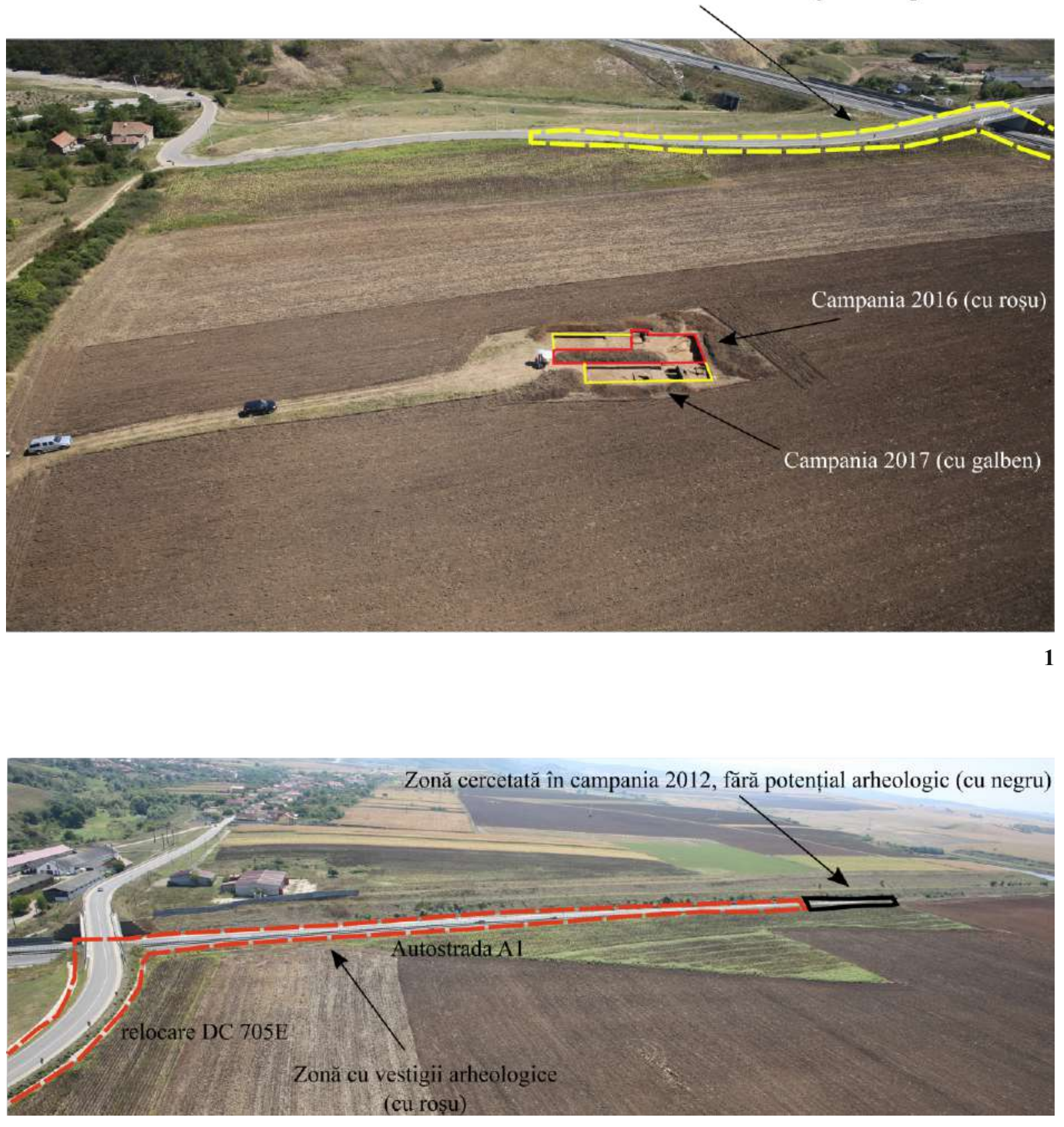

Imagini din dronă asupra zonei sitului - august 2017 (I). 1. Vedere spre est; 2. Vedere spre sud 


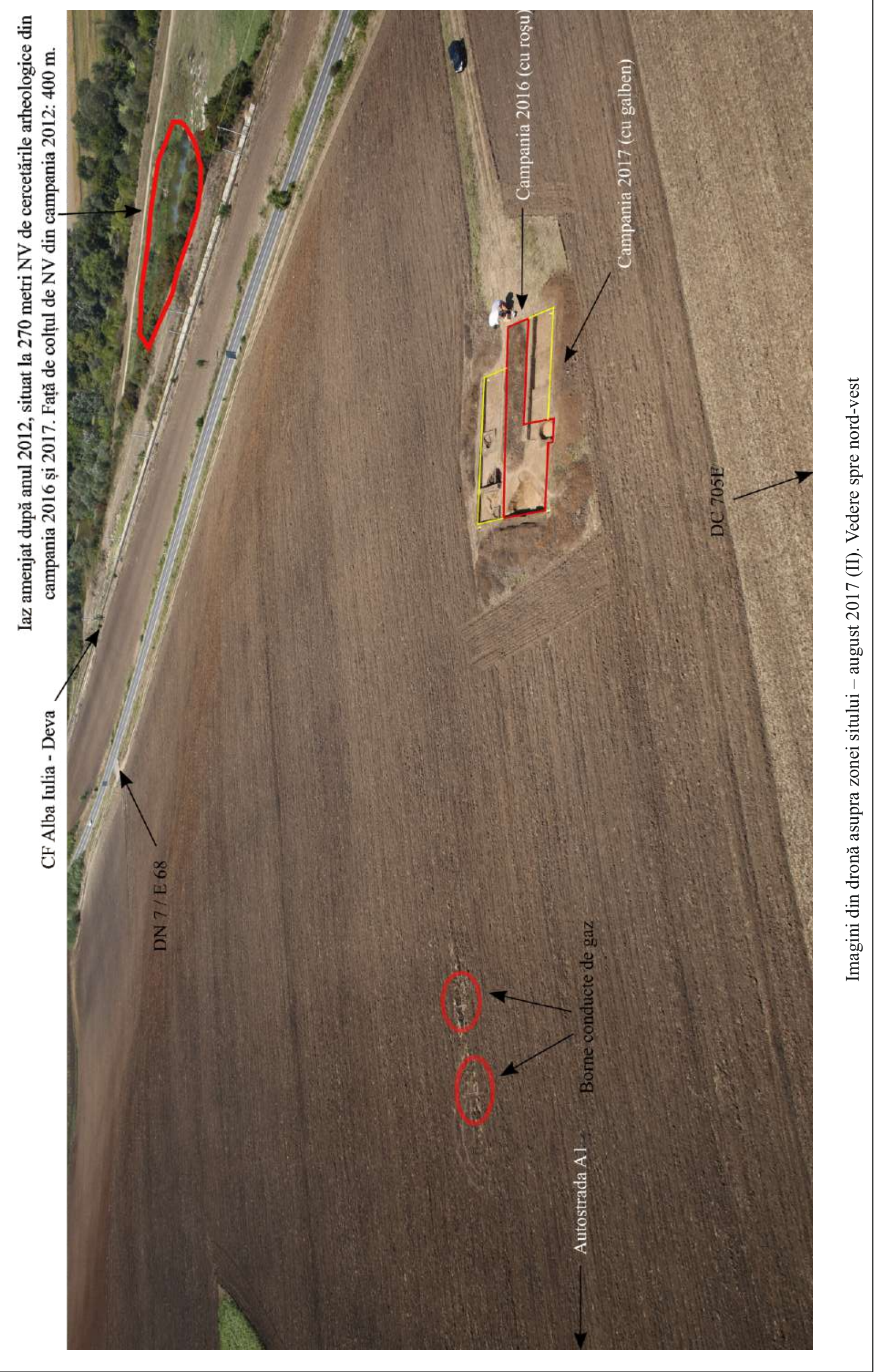




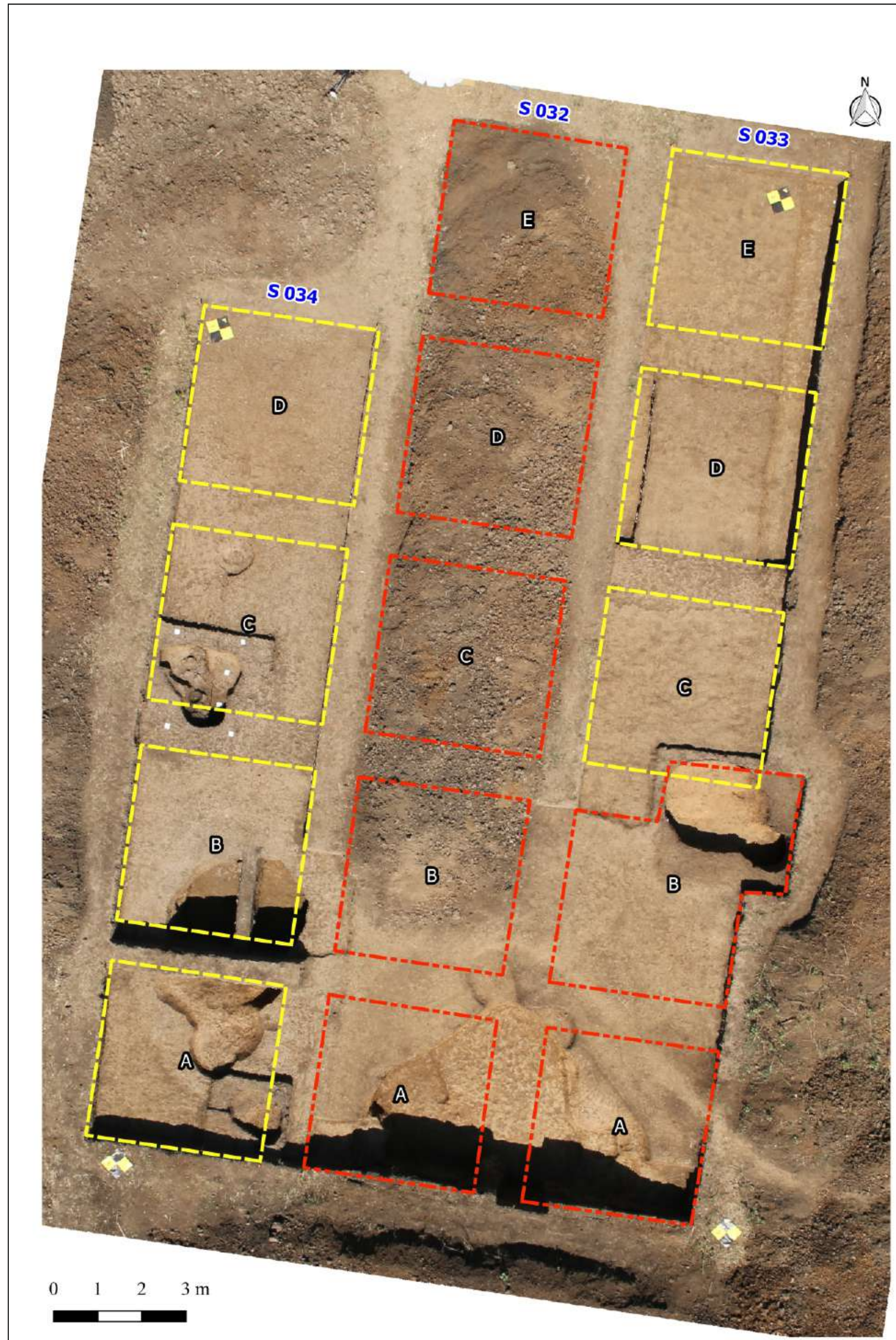

Amplasarea unităților de cercetare din campania 2016 (roșu) și campania 2017 (galben) 


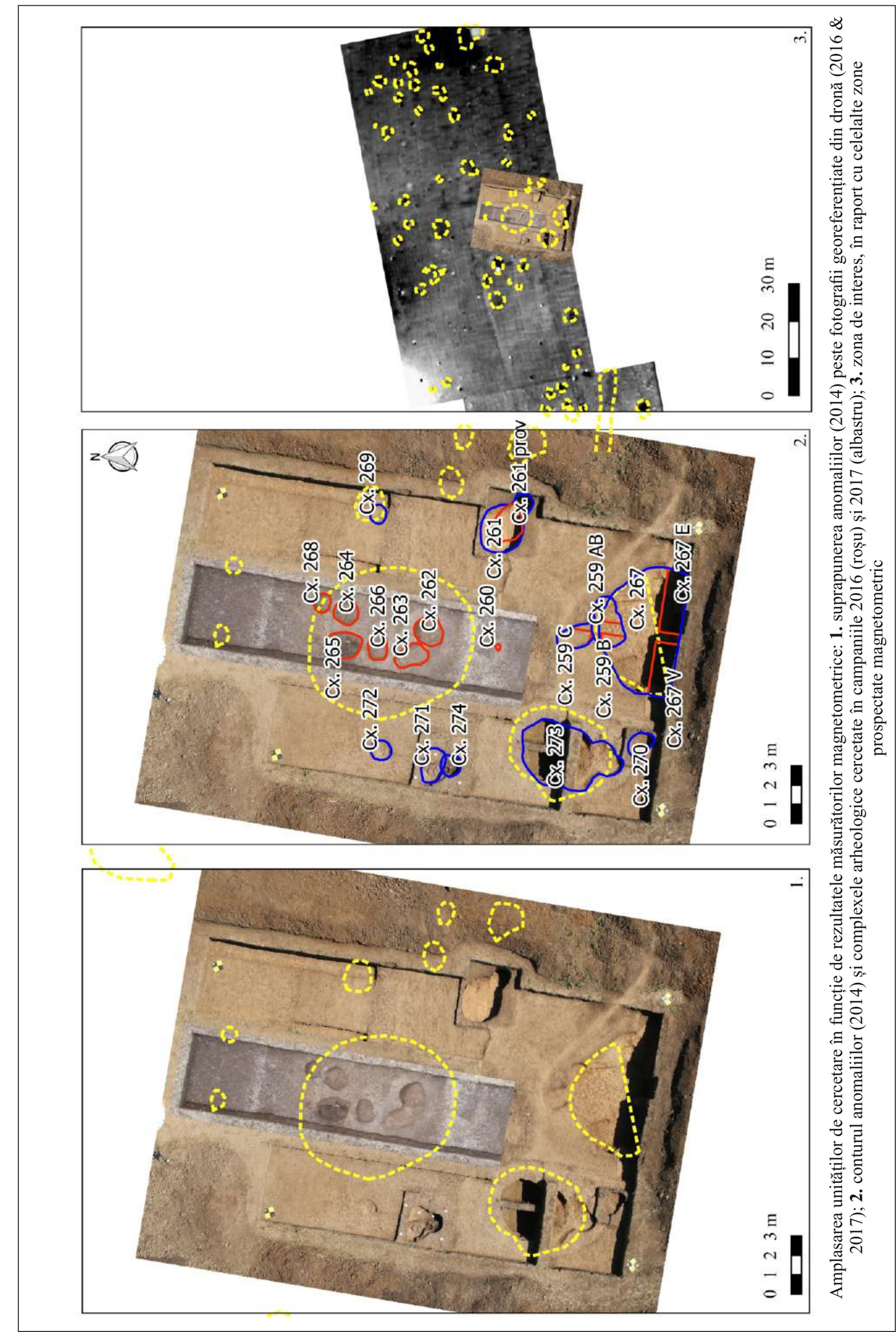



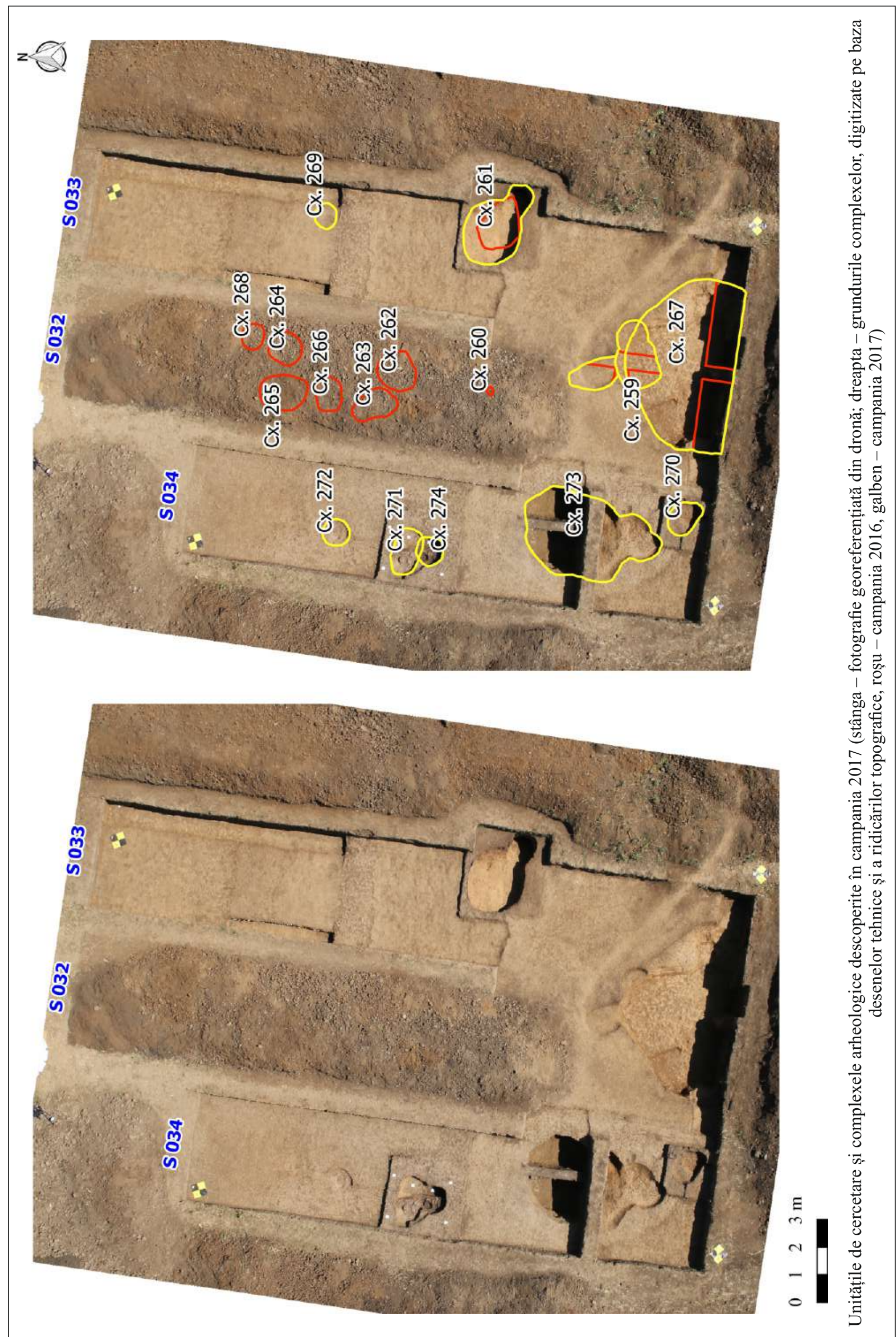


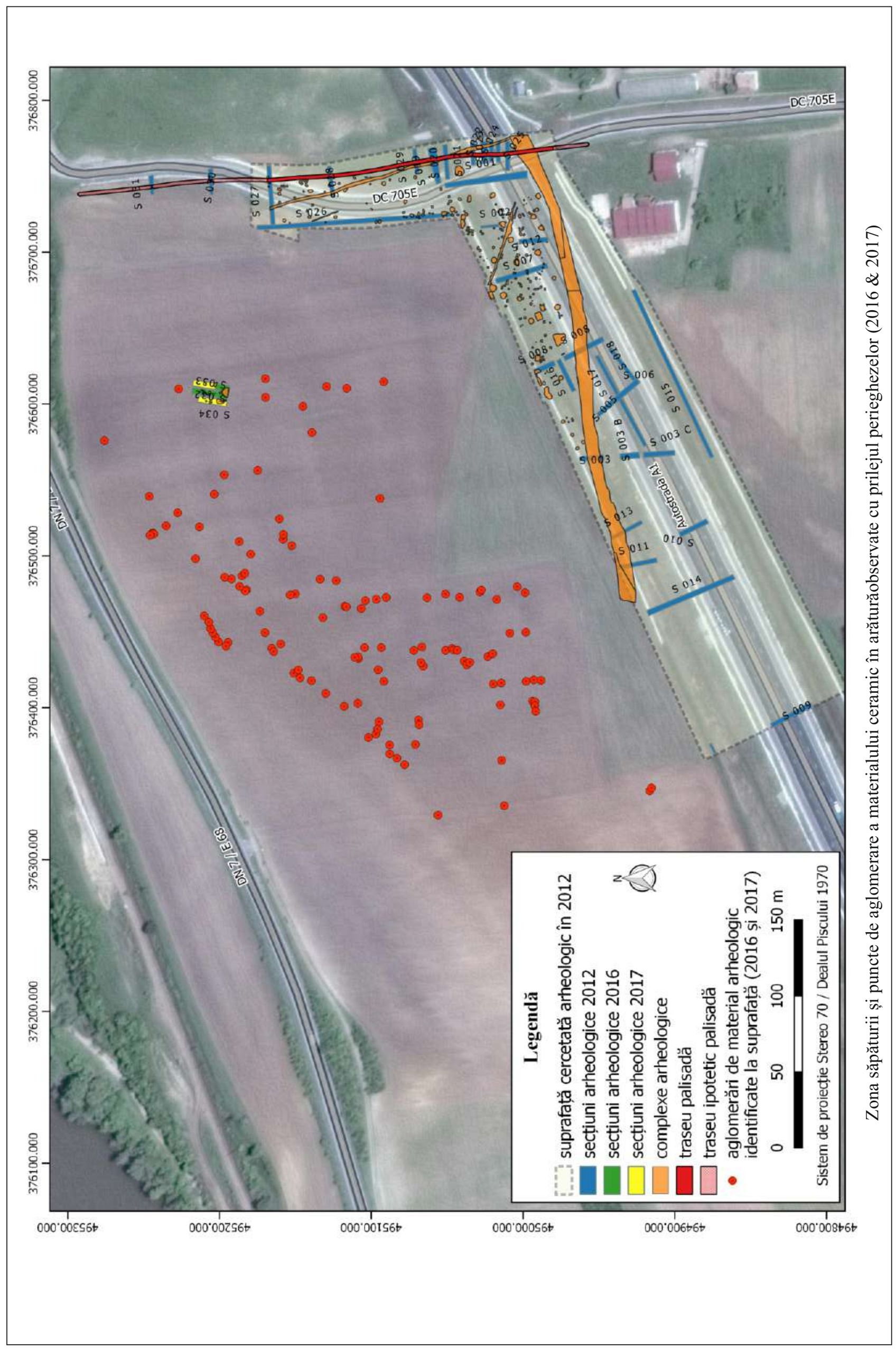




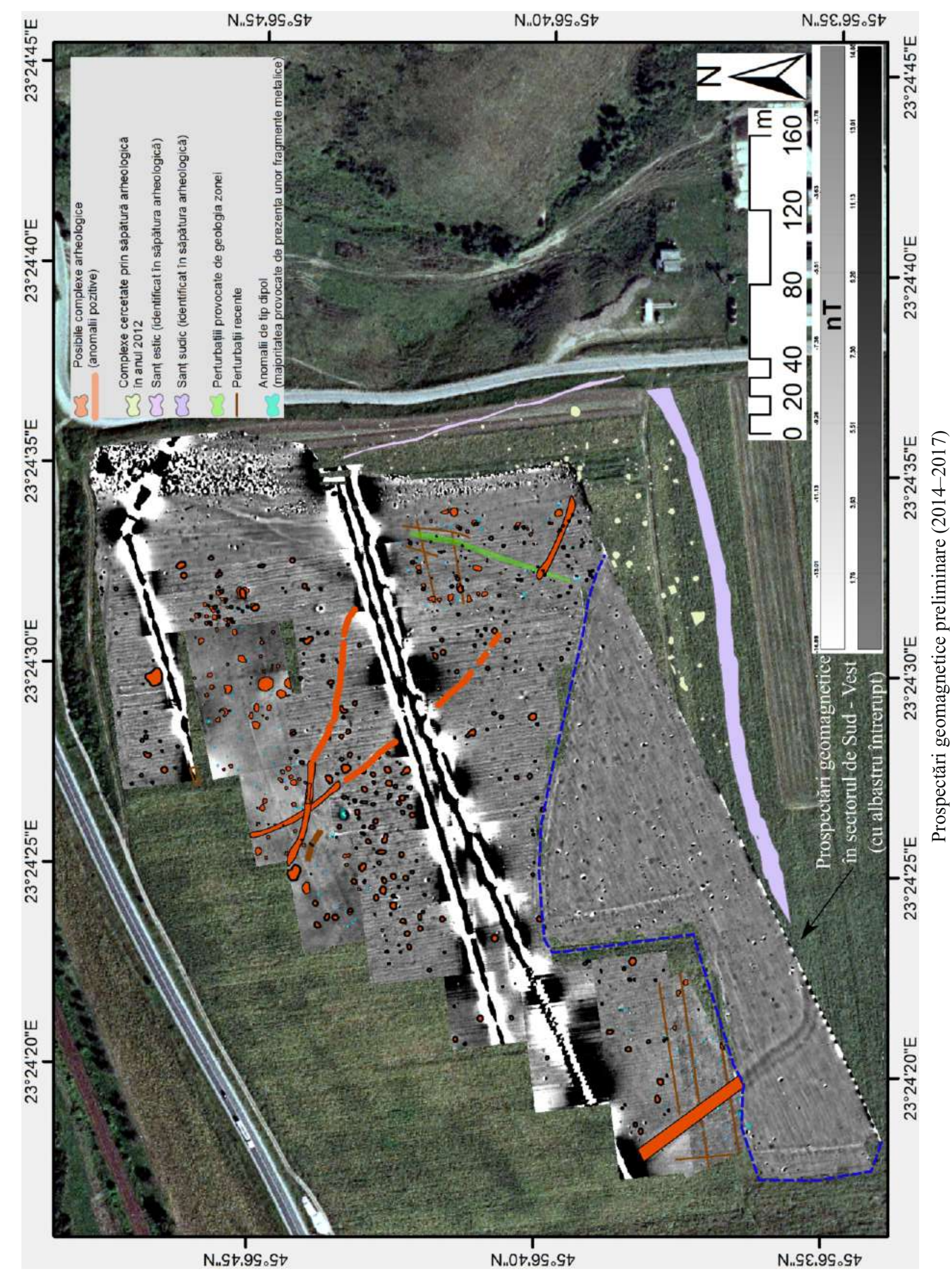

$x$ 


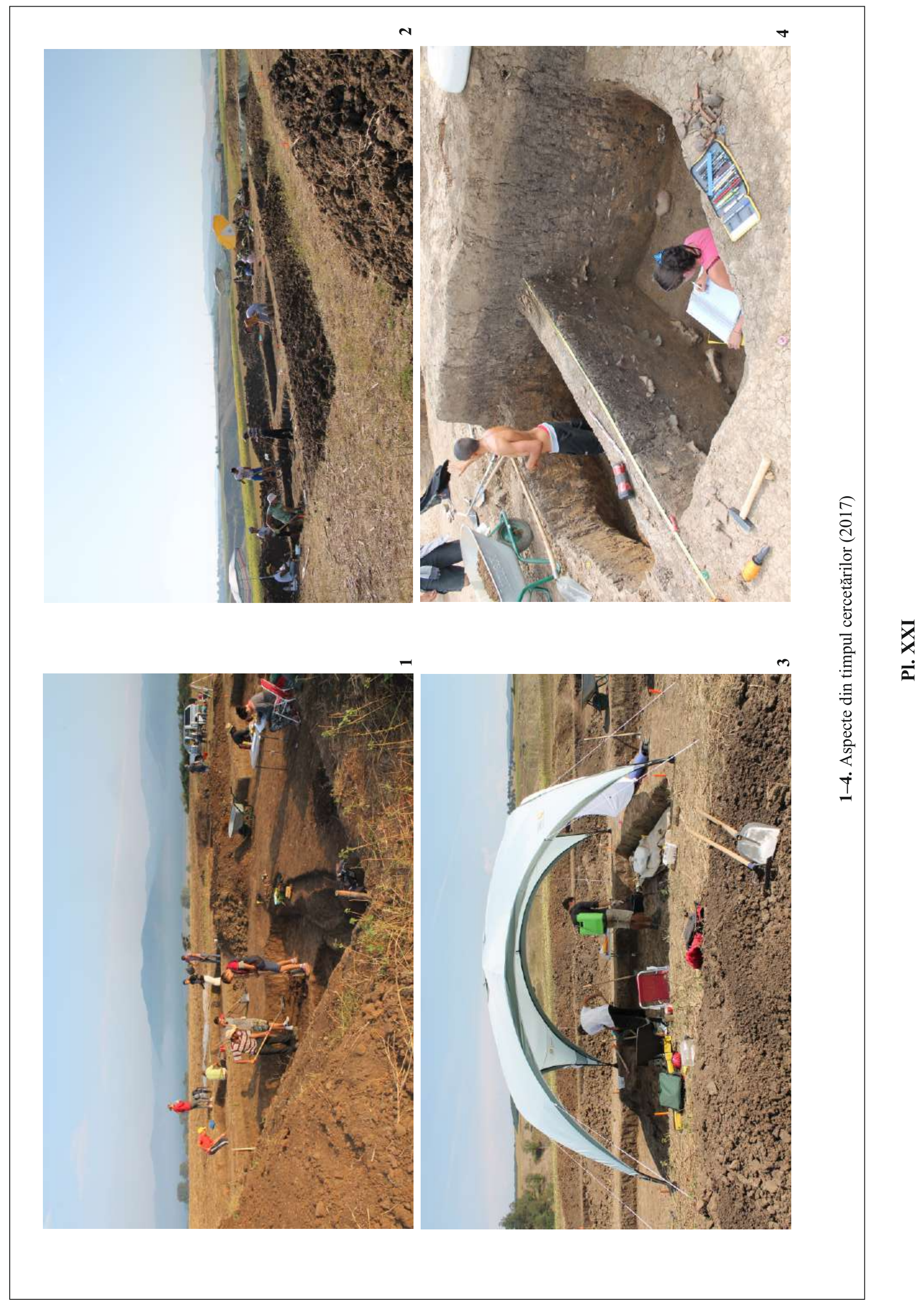




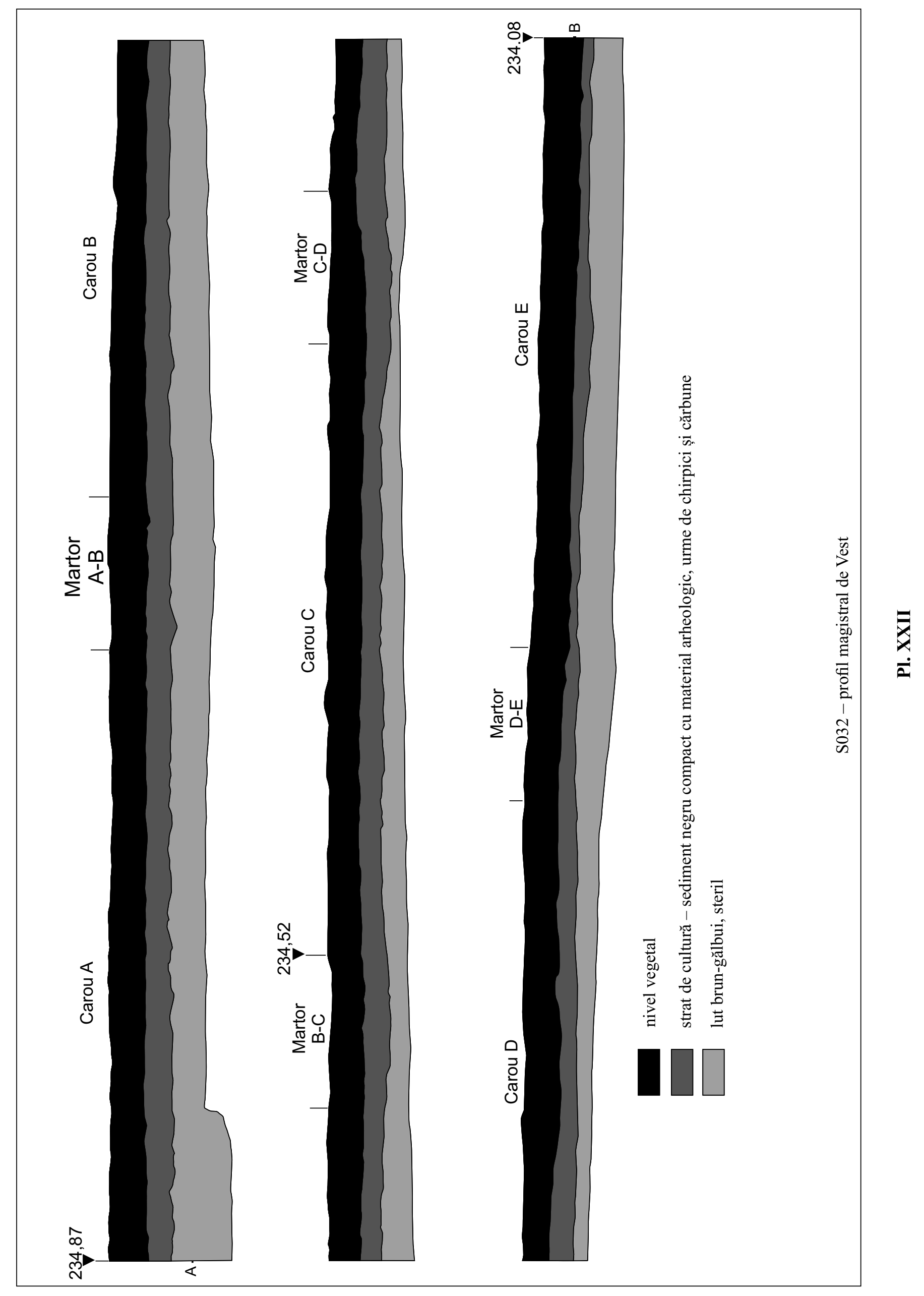




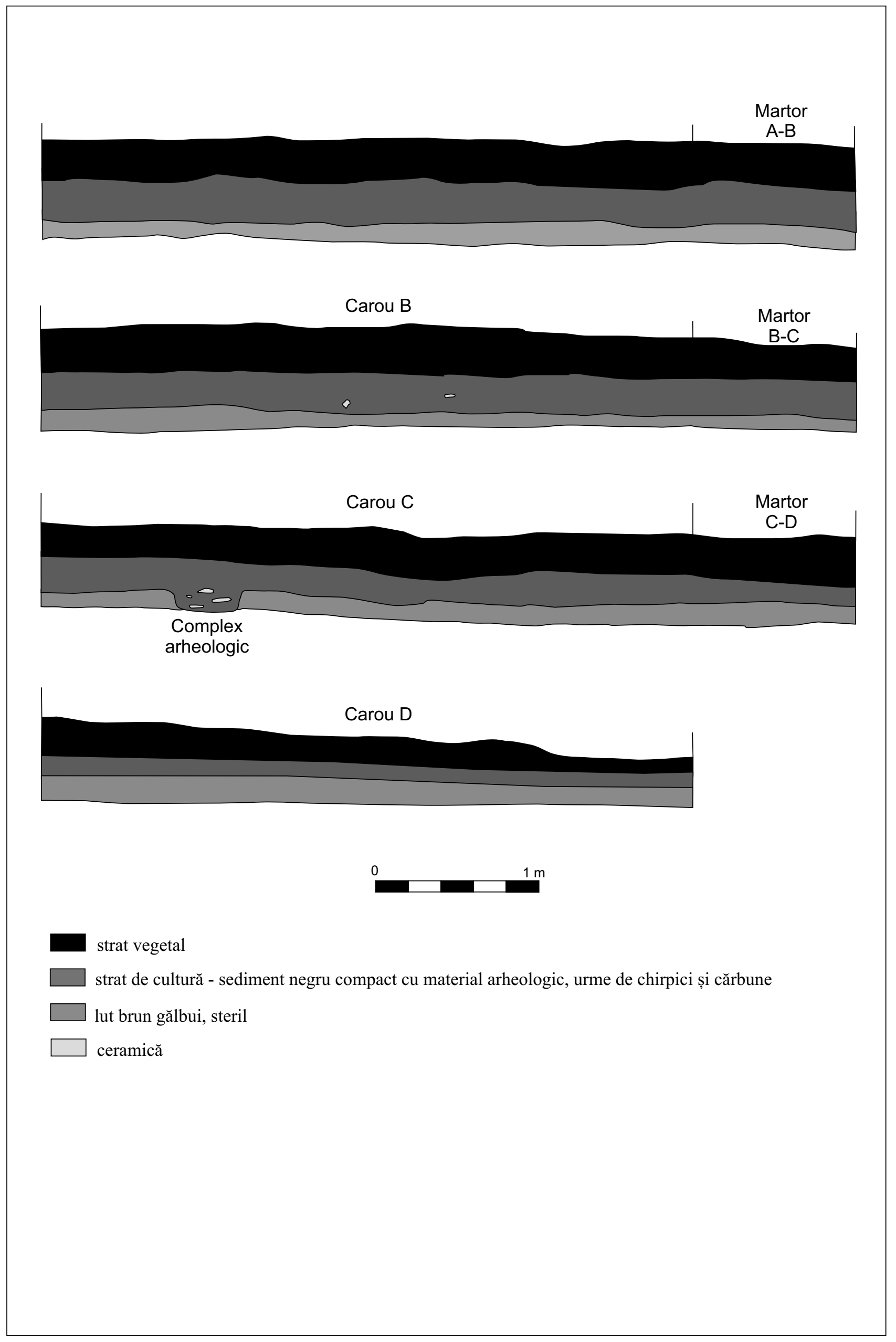




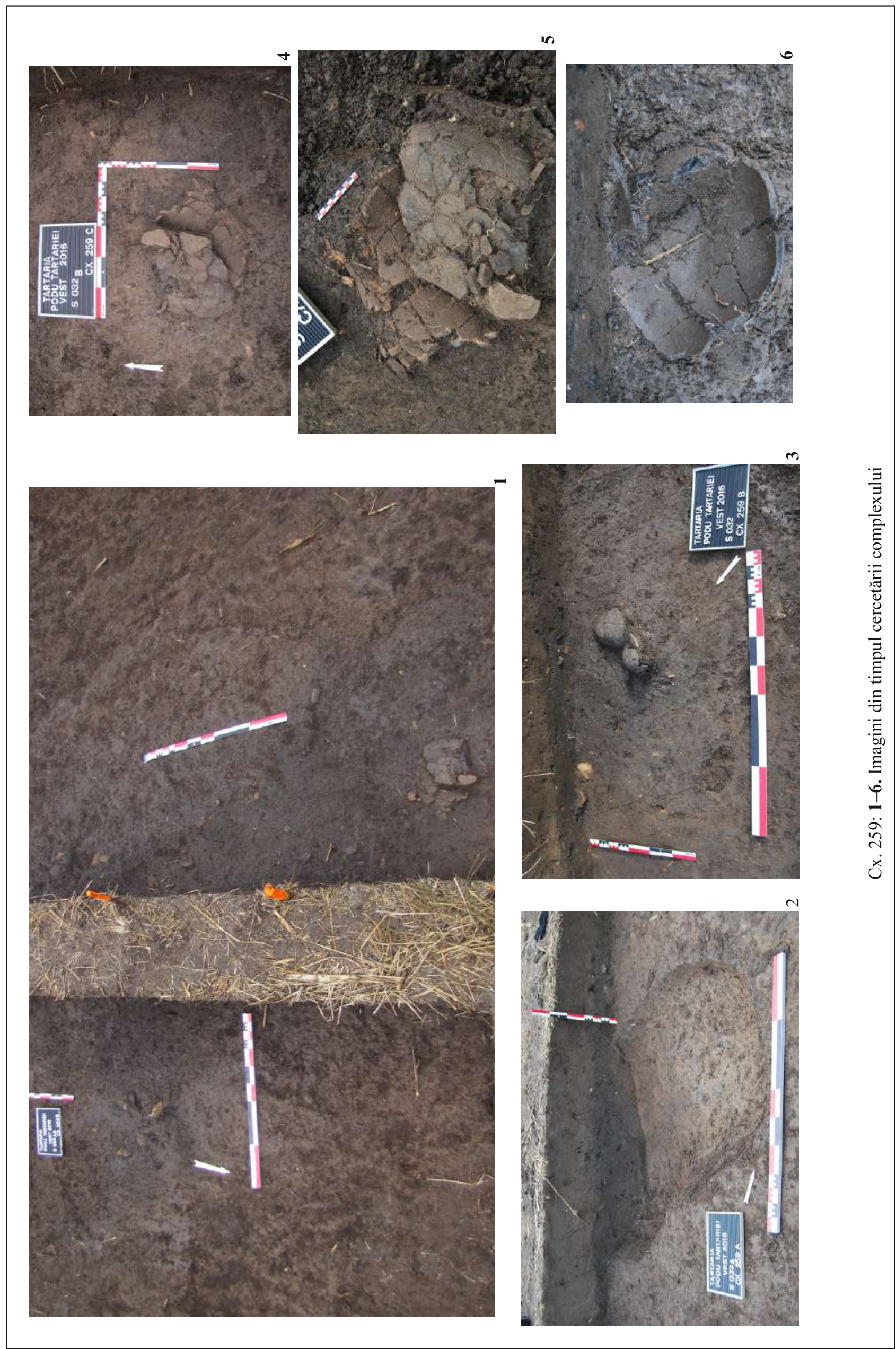




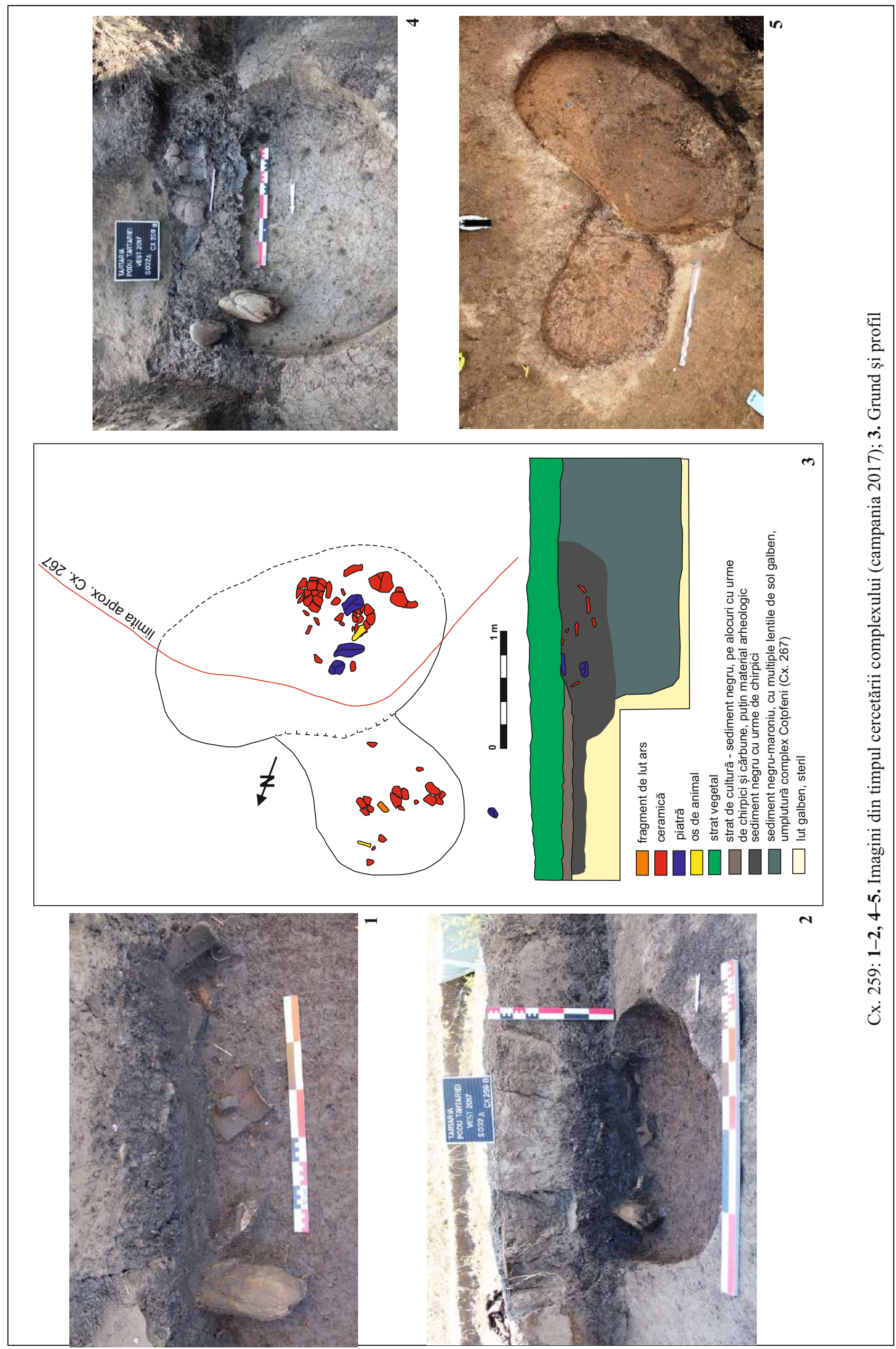

$x$
$x$
2 

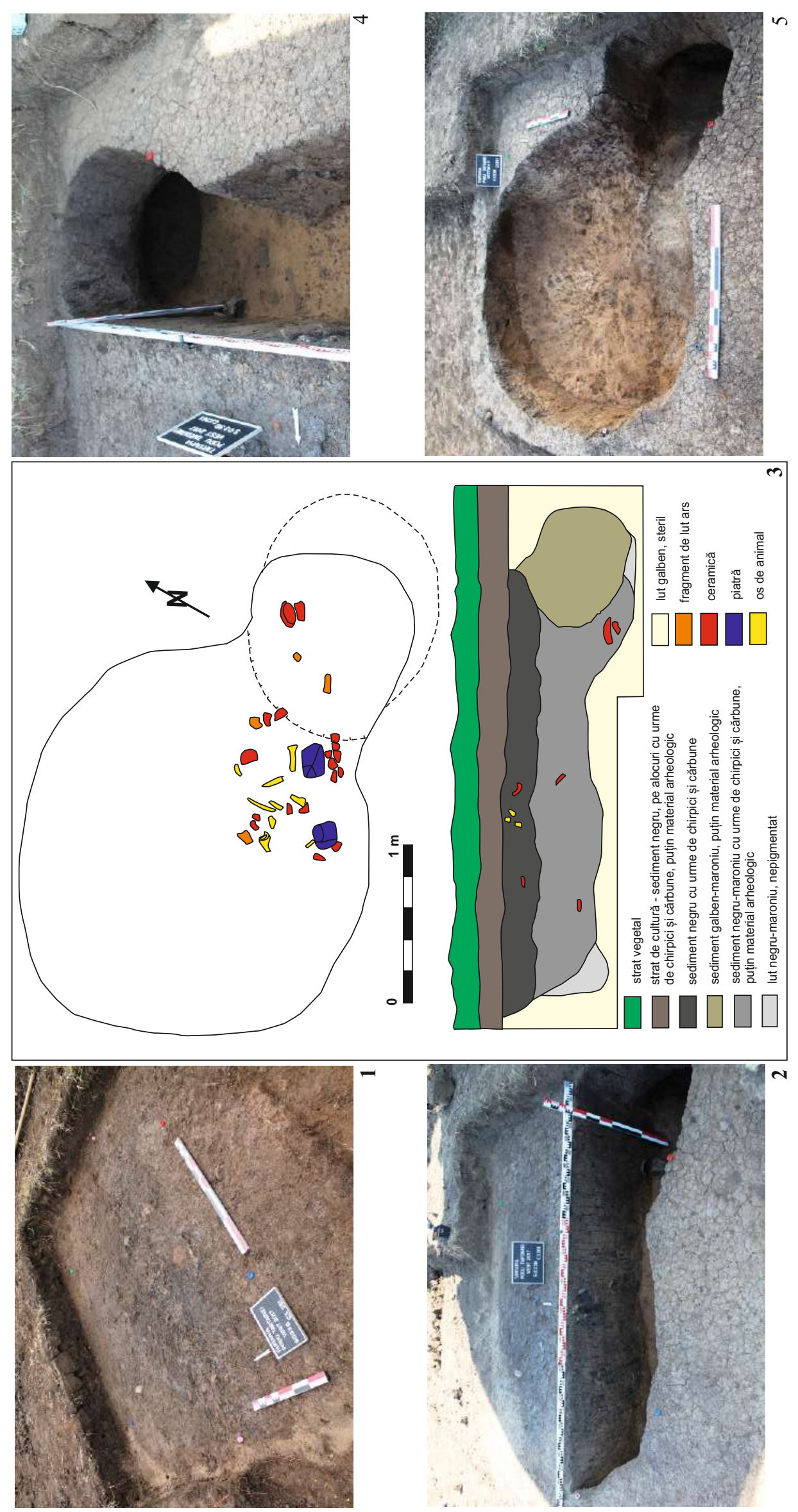

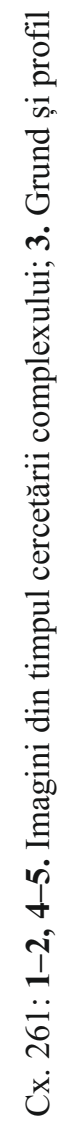




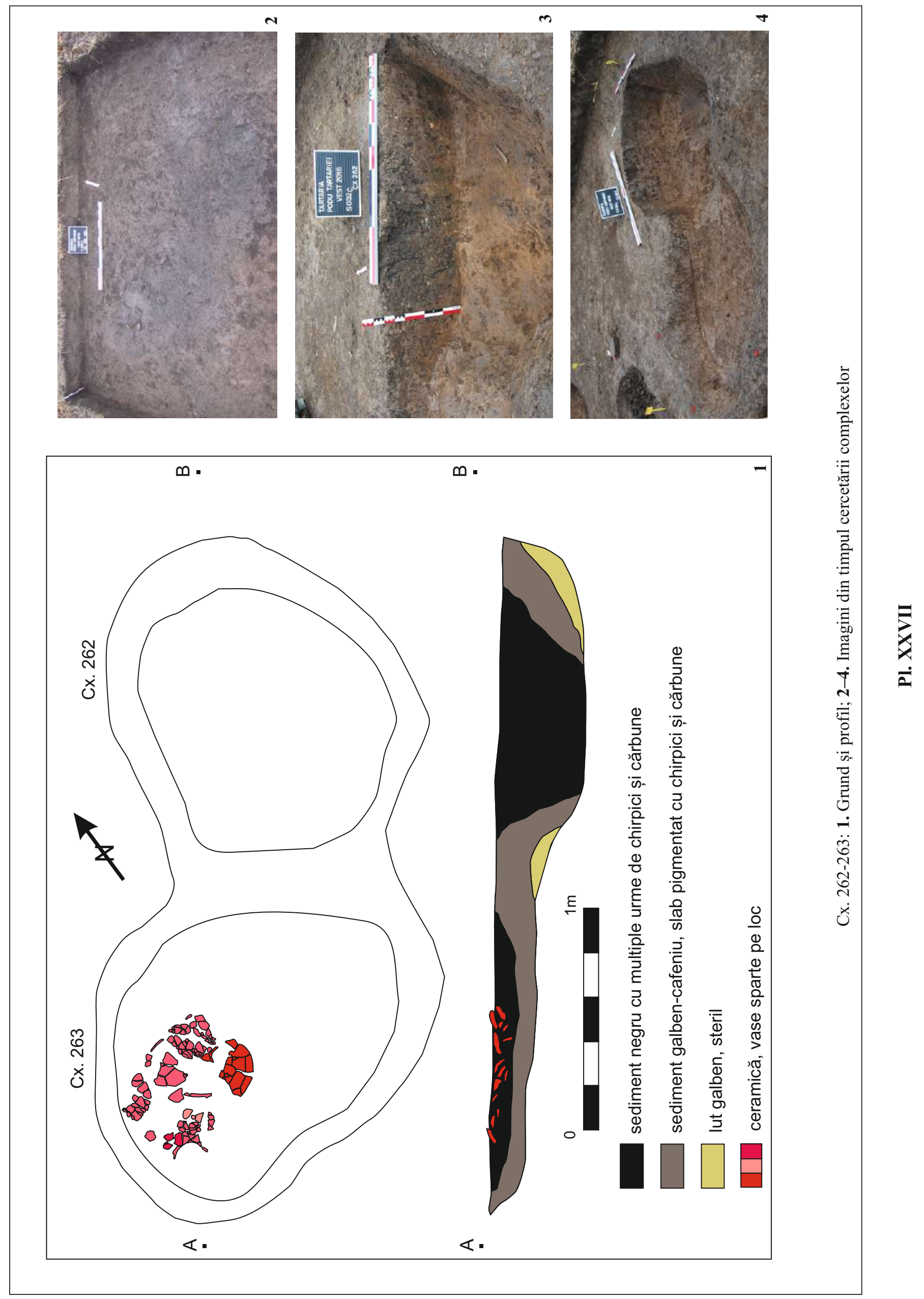



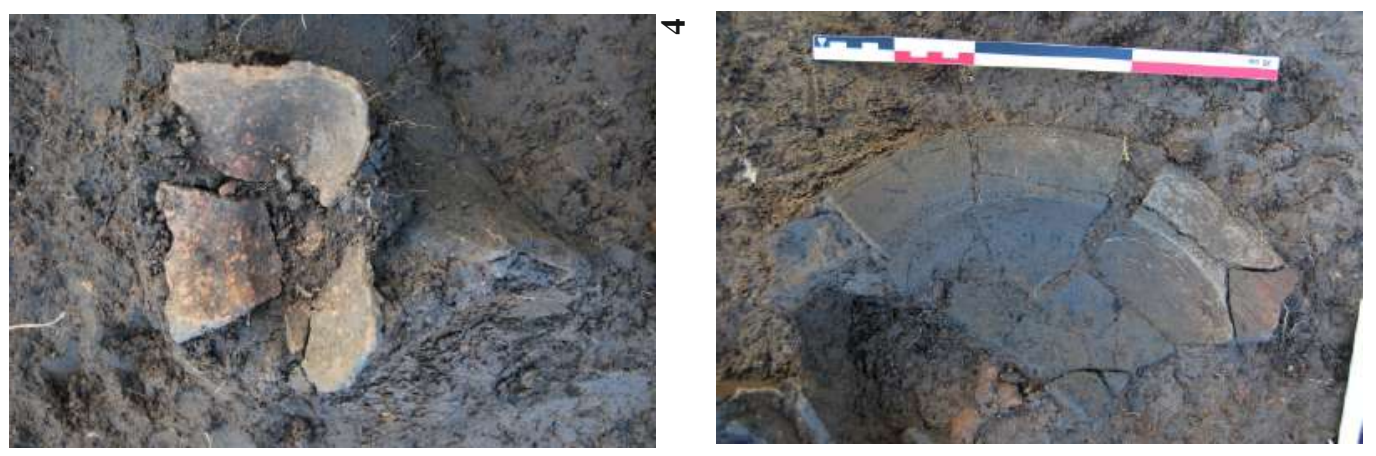

in
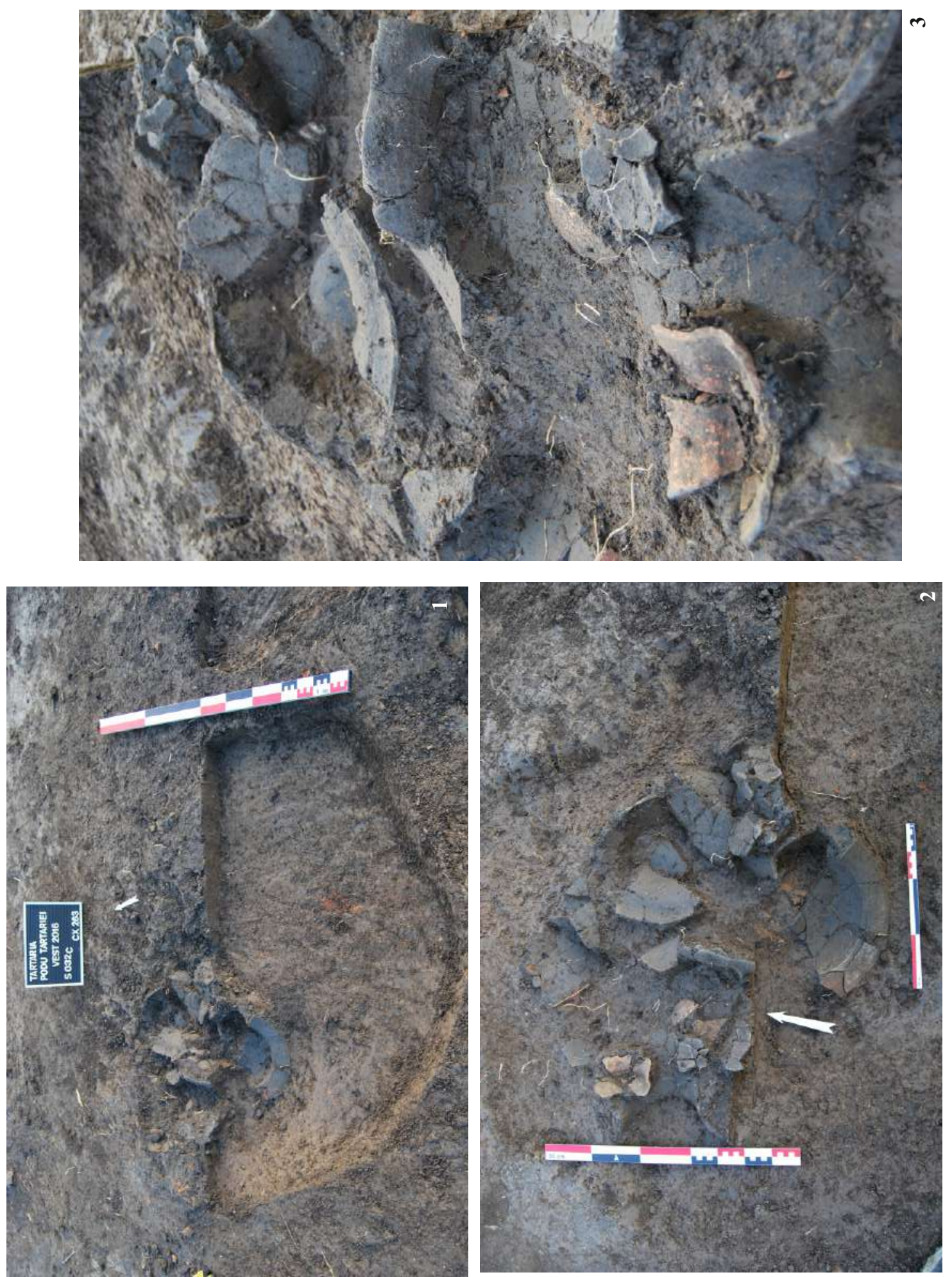

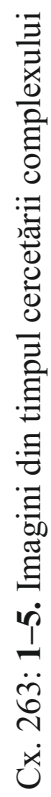




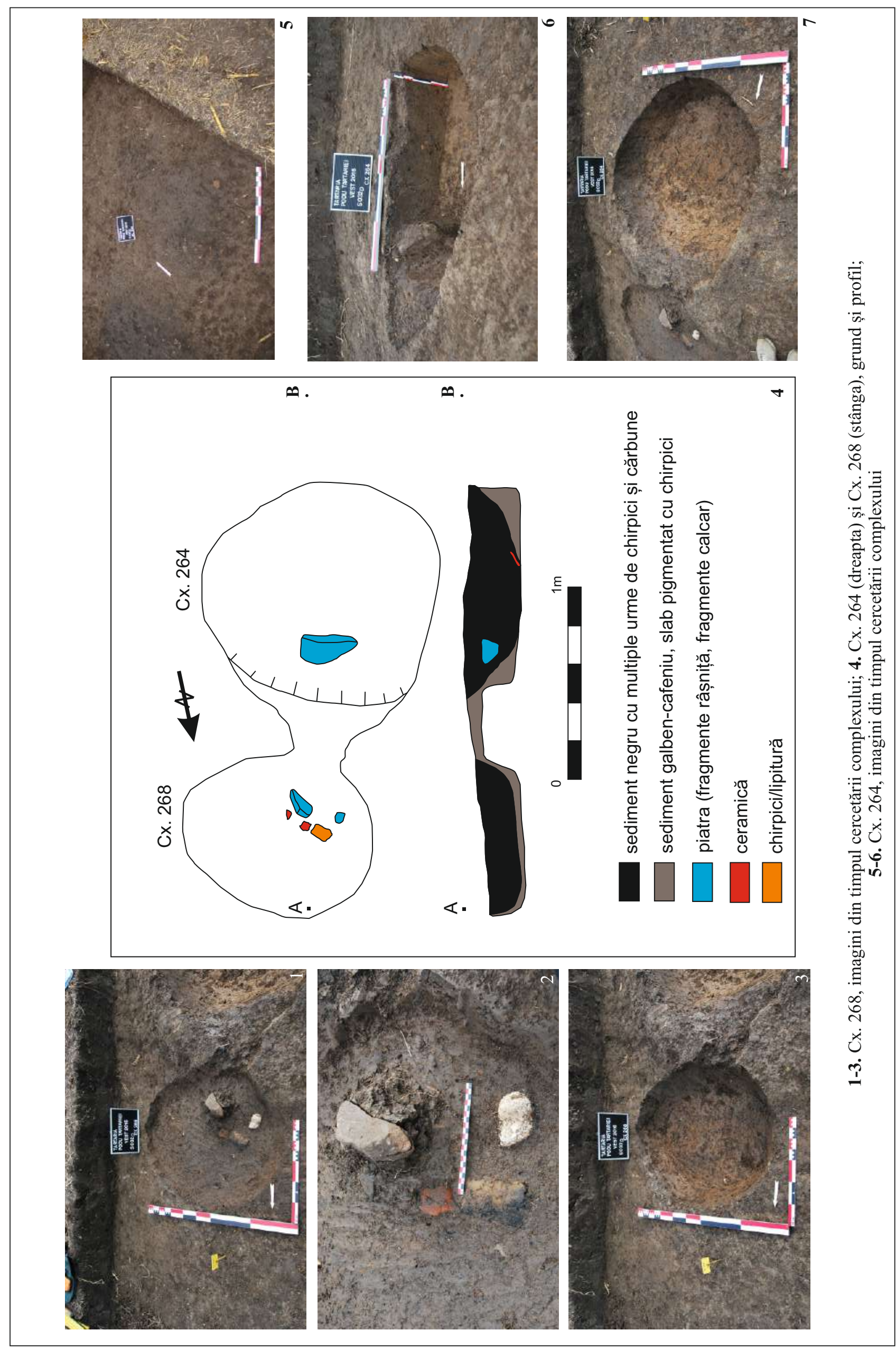




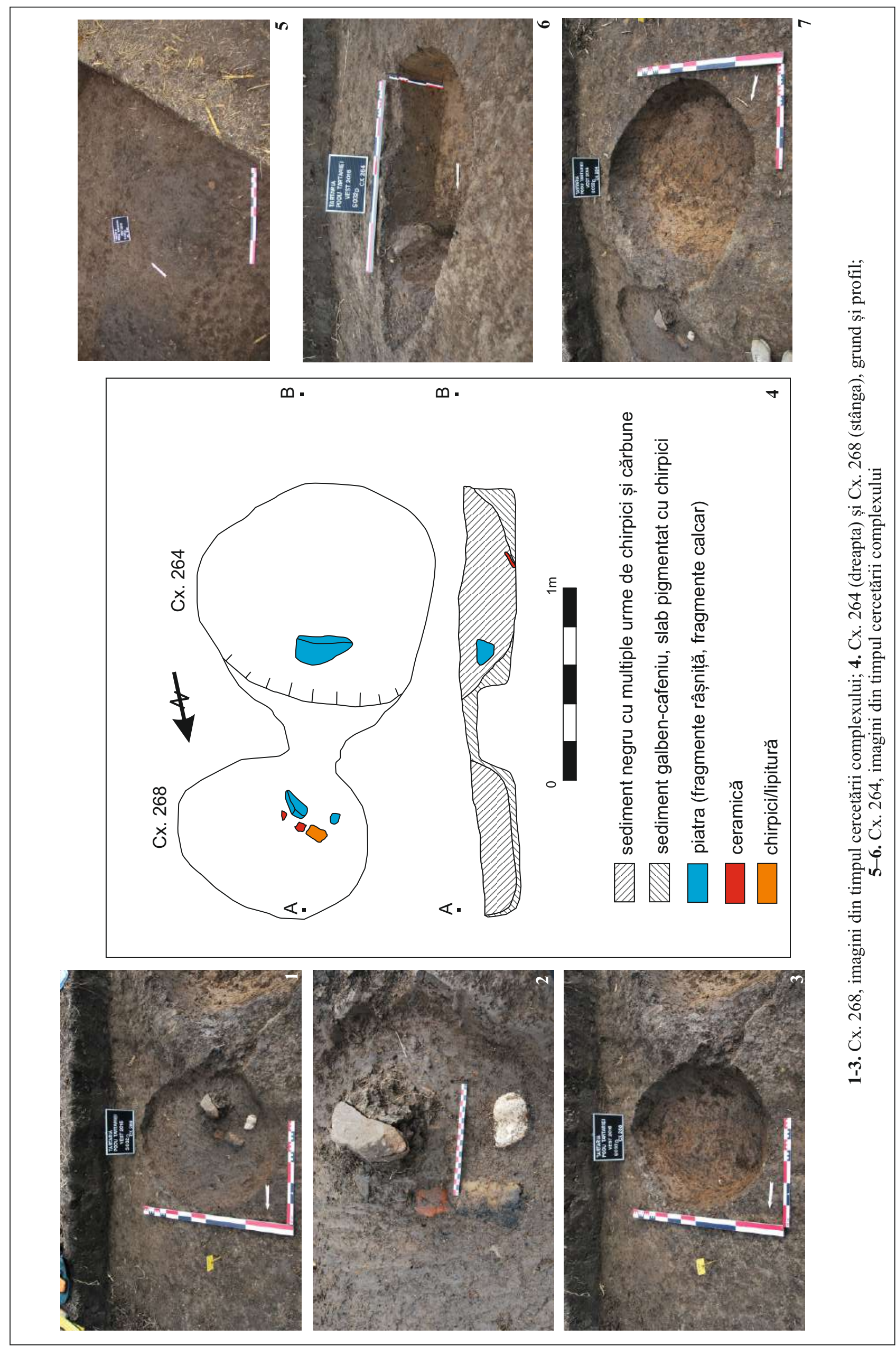



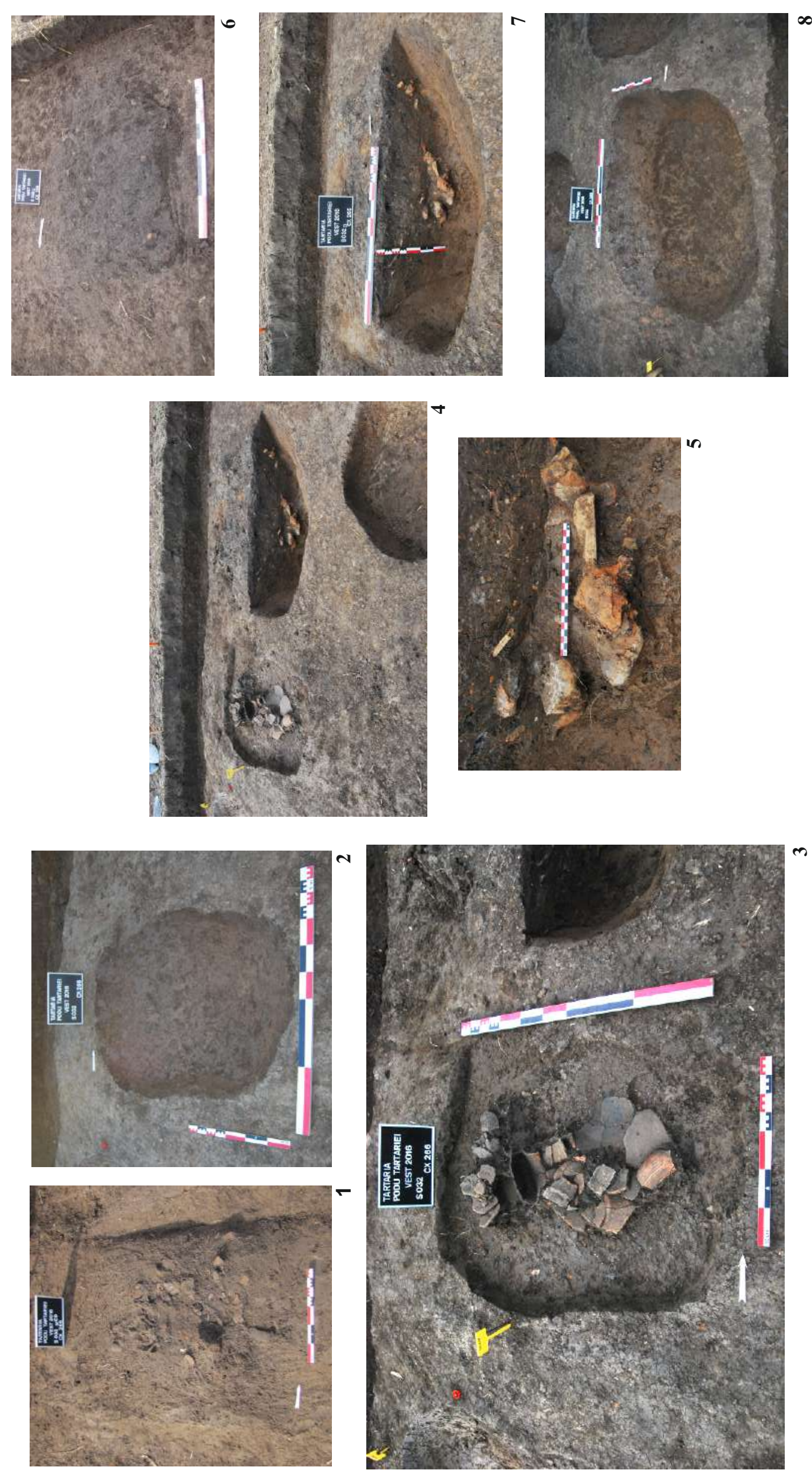

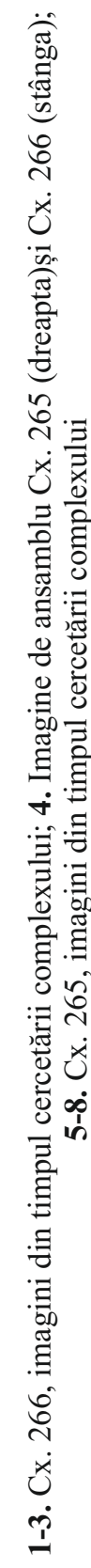

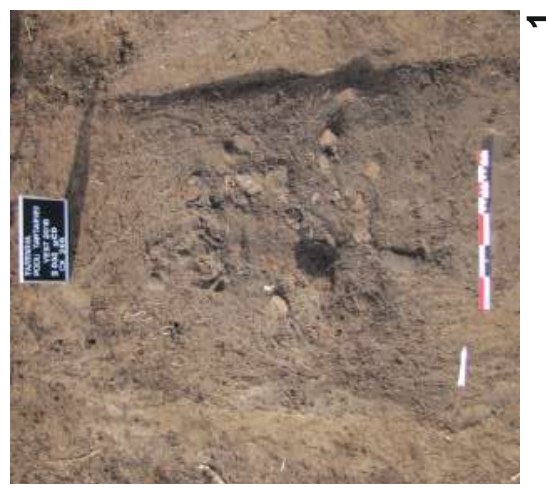



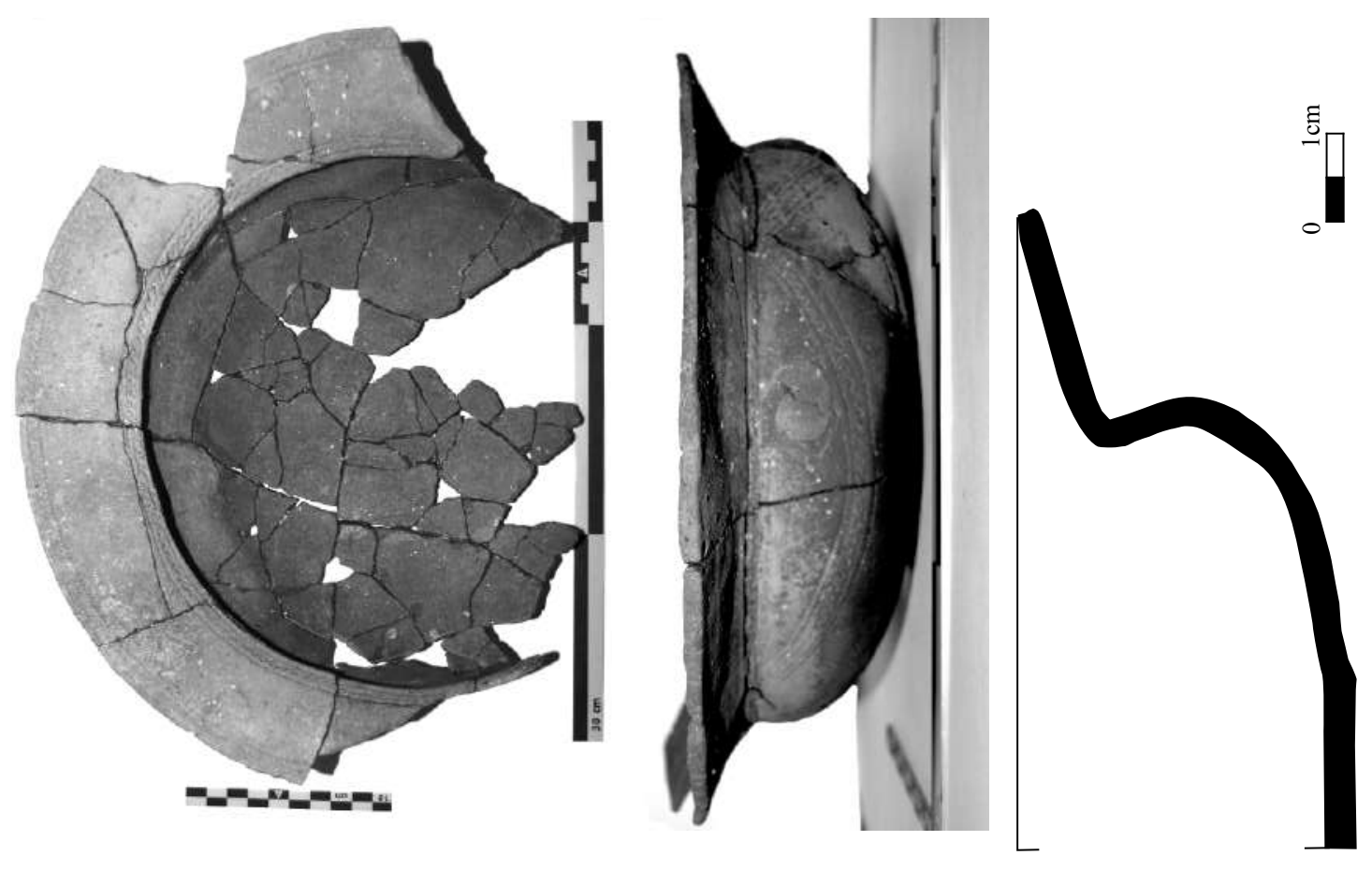

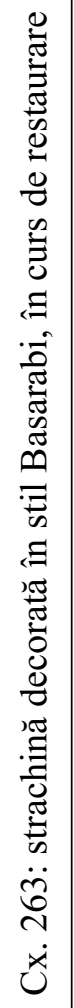

$\bar{x}$
$\dot{x}$
$\dot{a}$

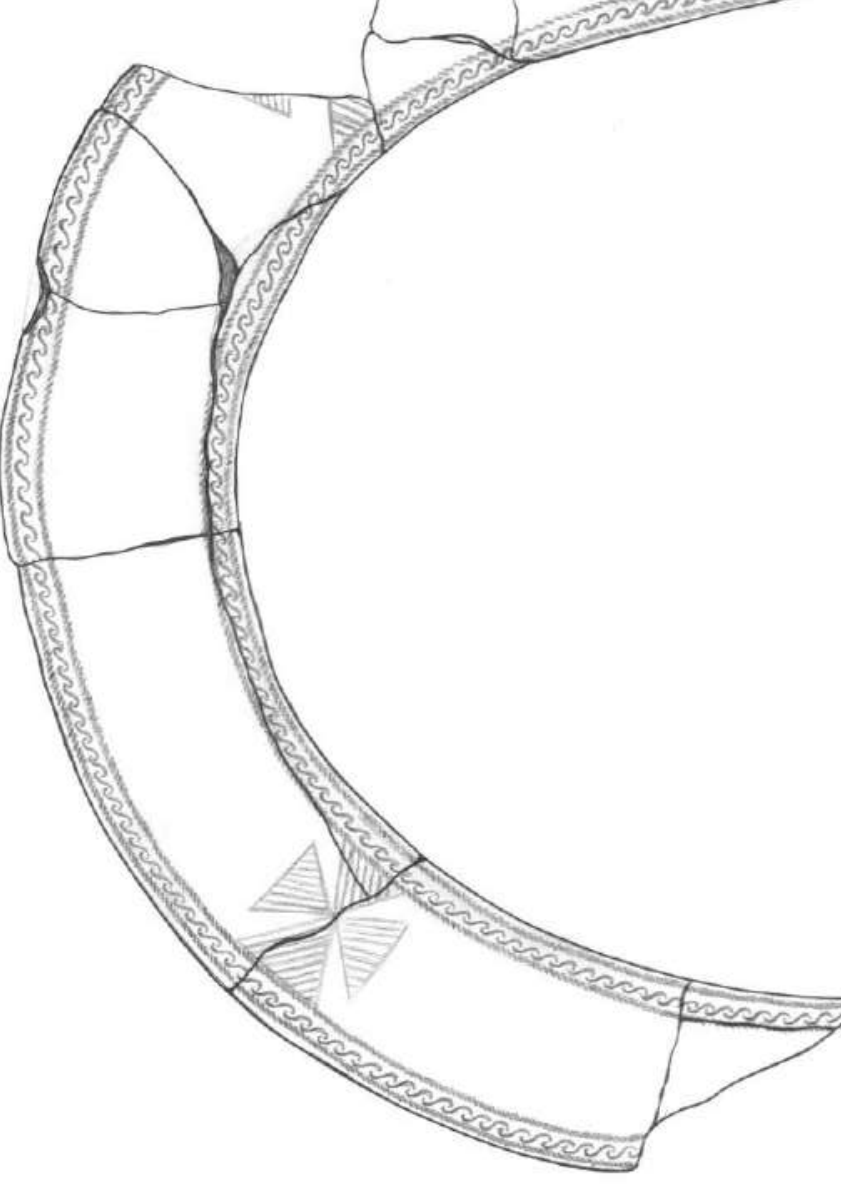




$$
\text { th }
$$




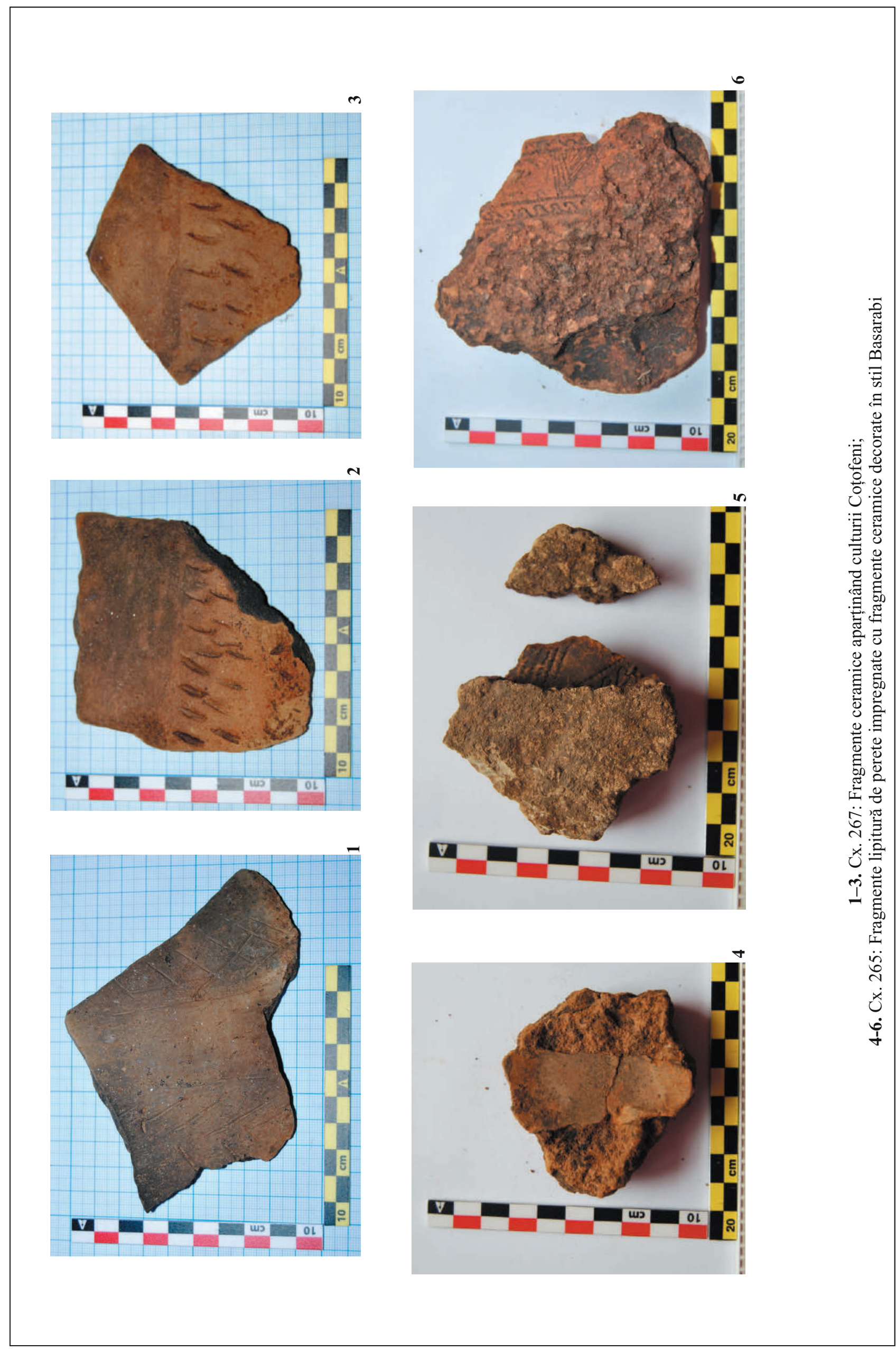



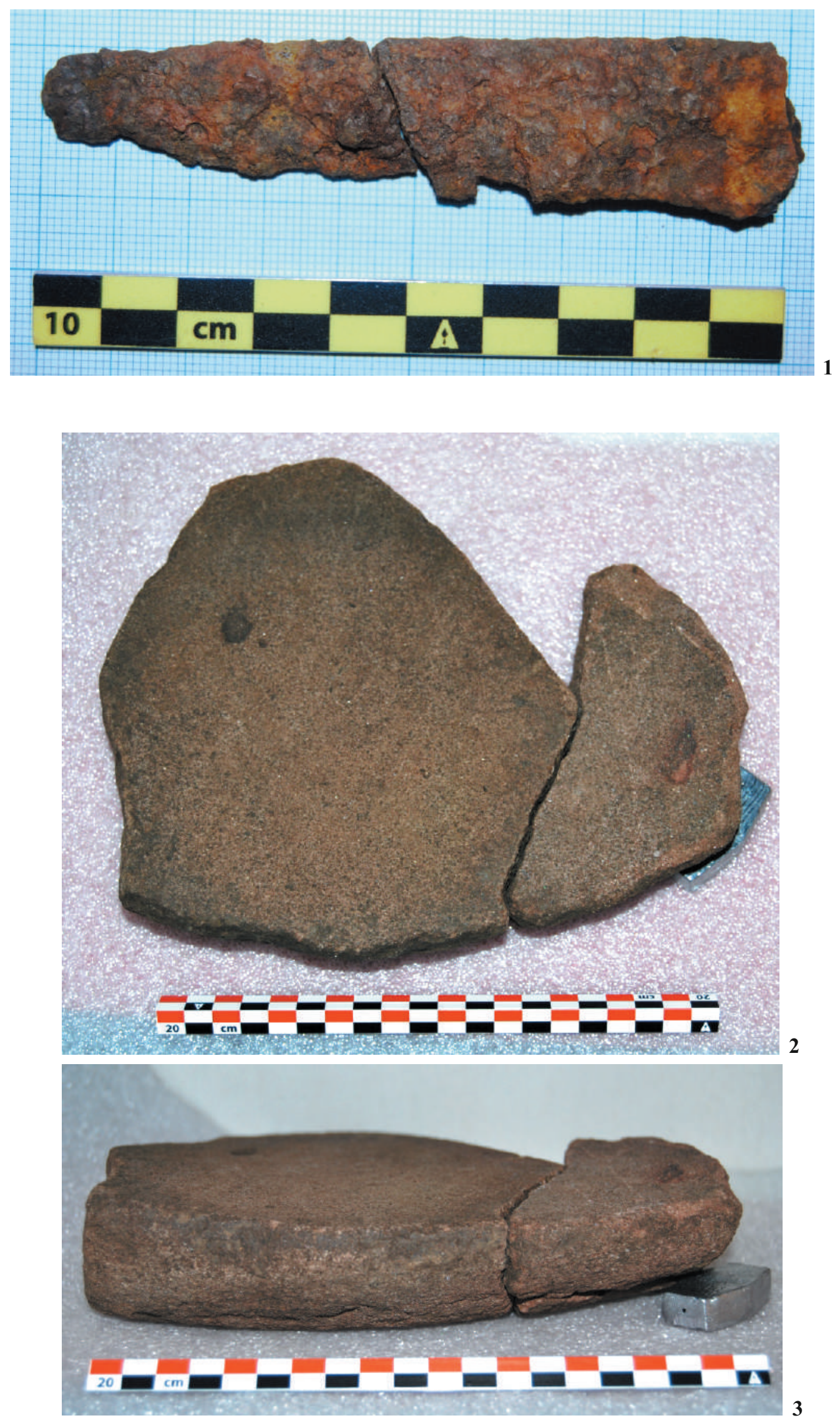

1. Cx. 259 B: Lamă cuțit din Fe fragmentară; 2-3. Cx. 266: Râșniță fragmentară 


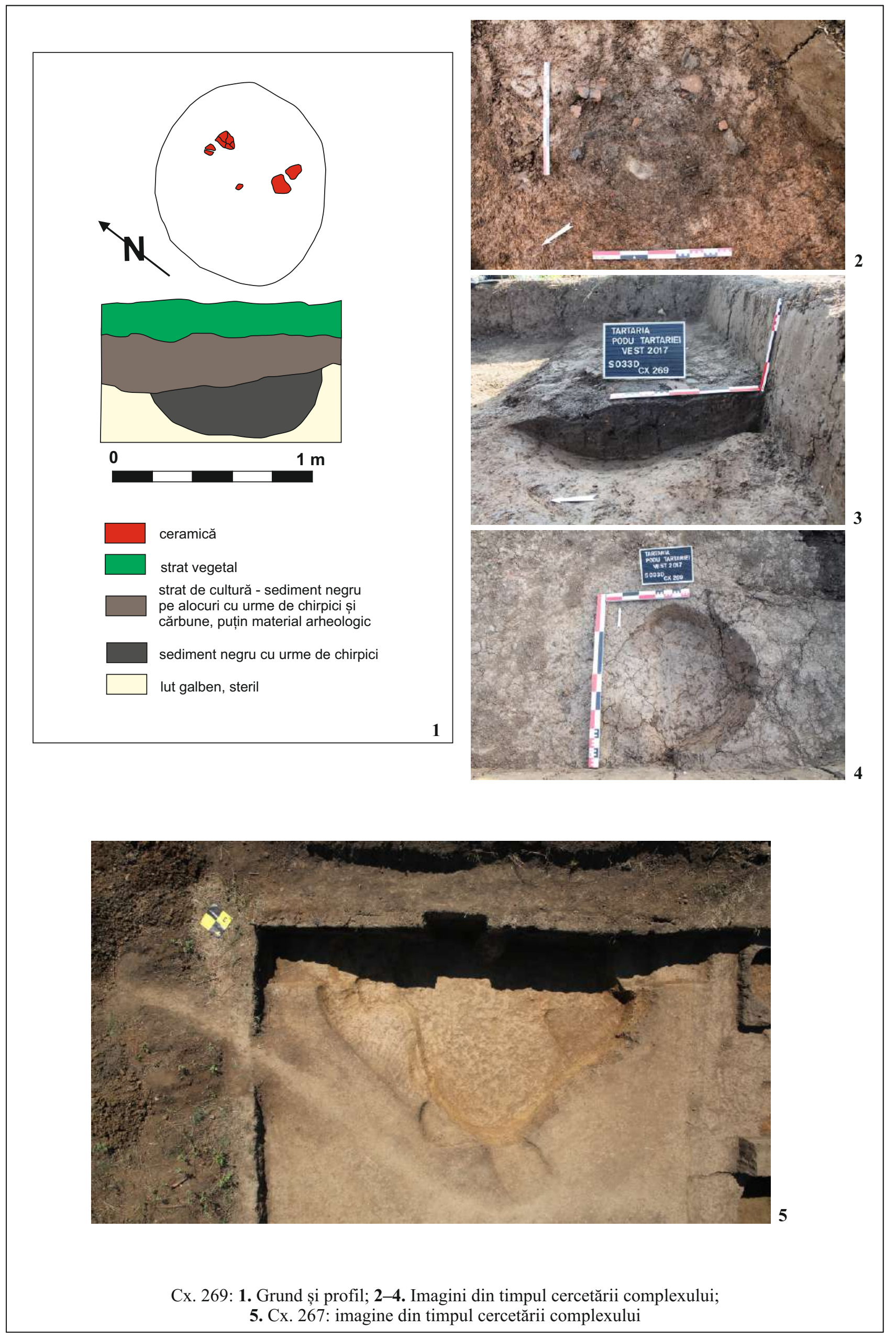




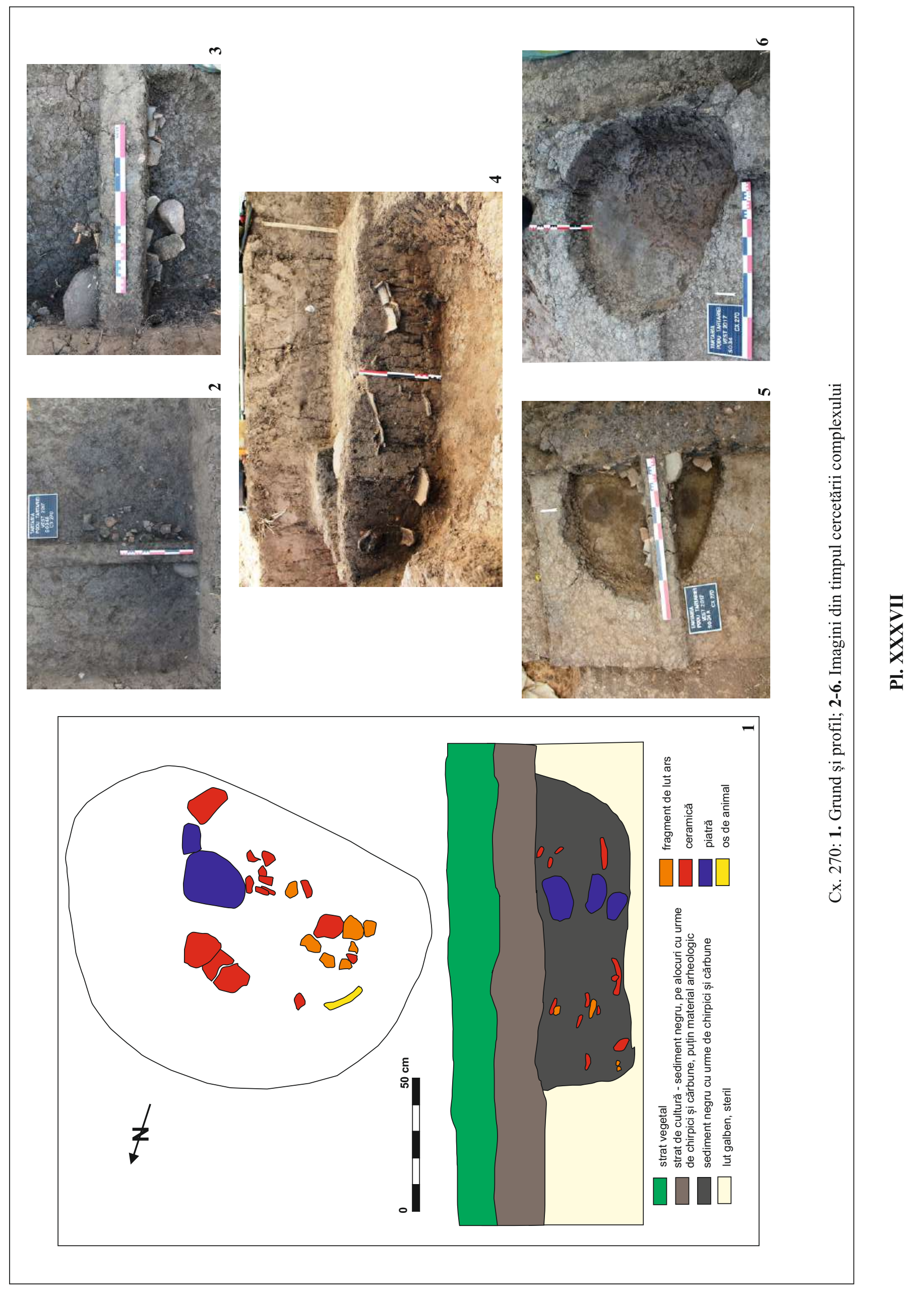




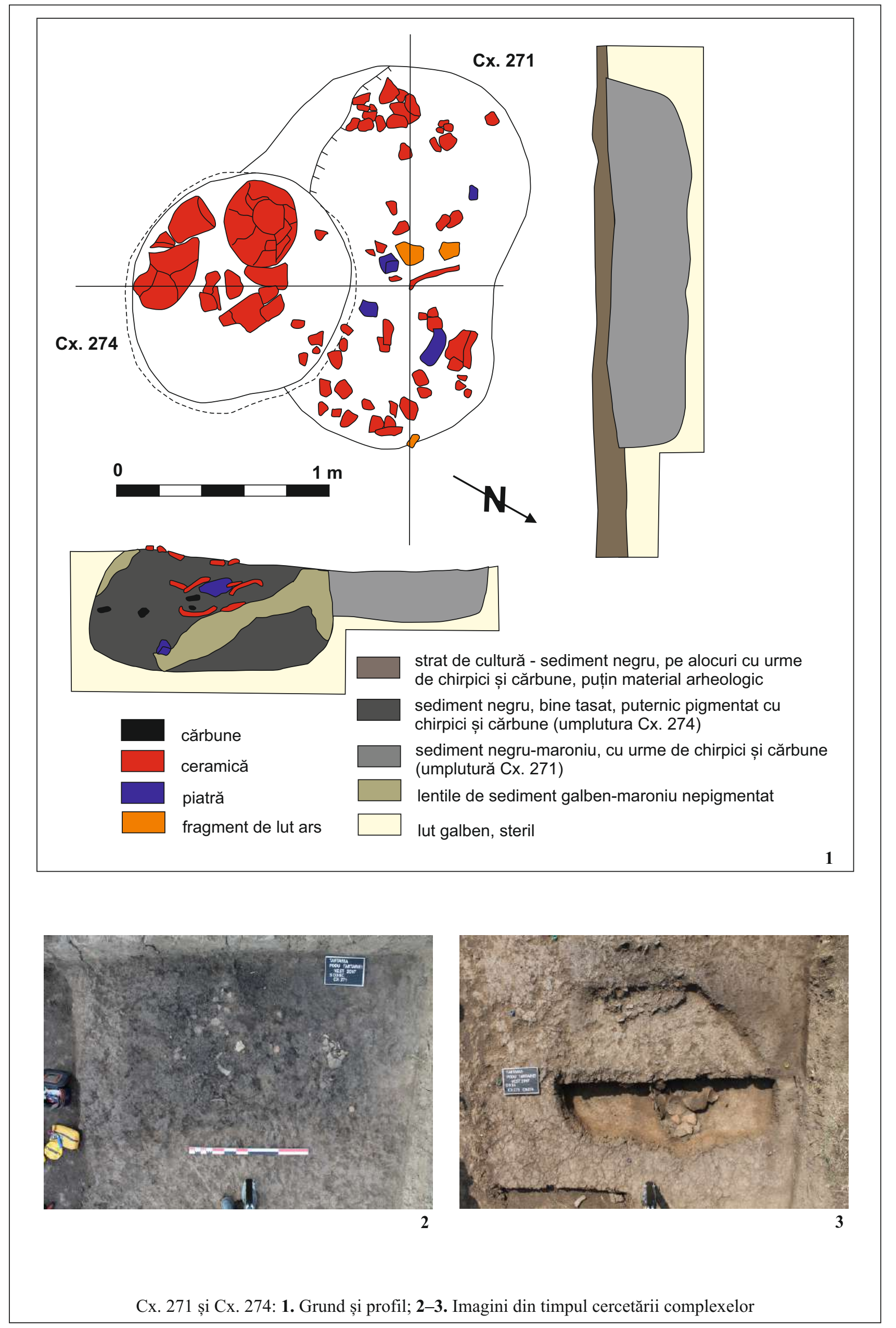



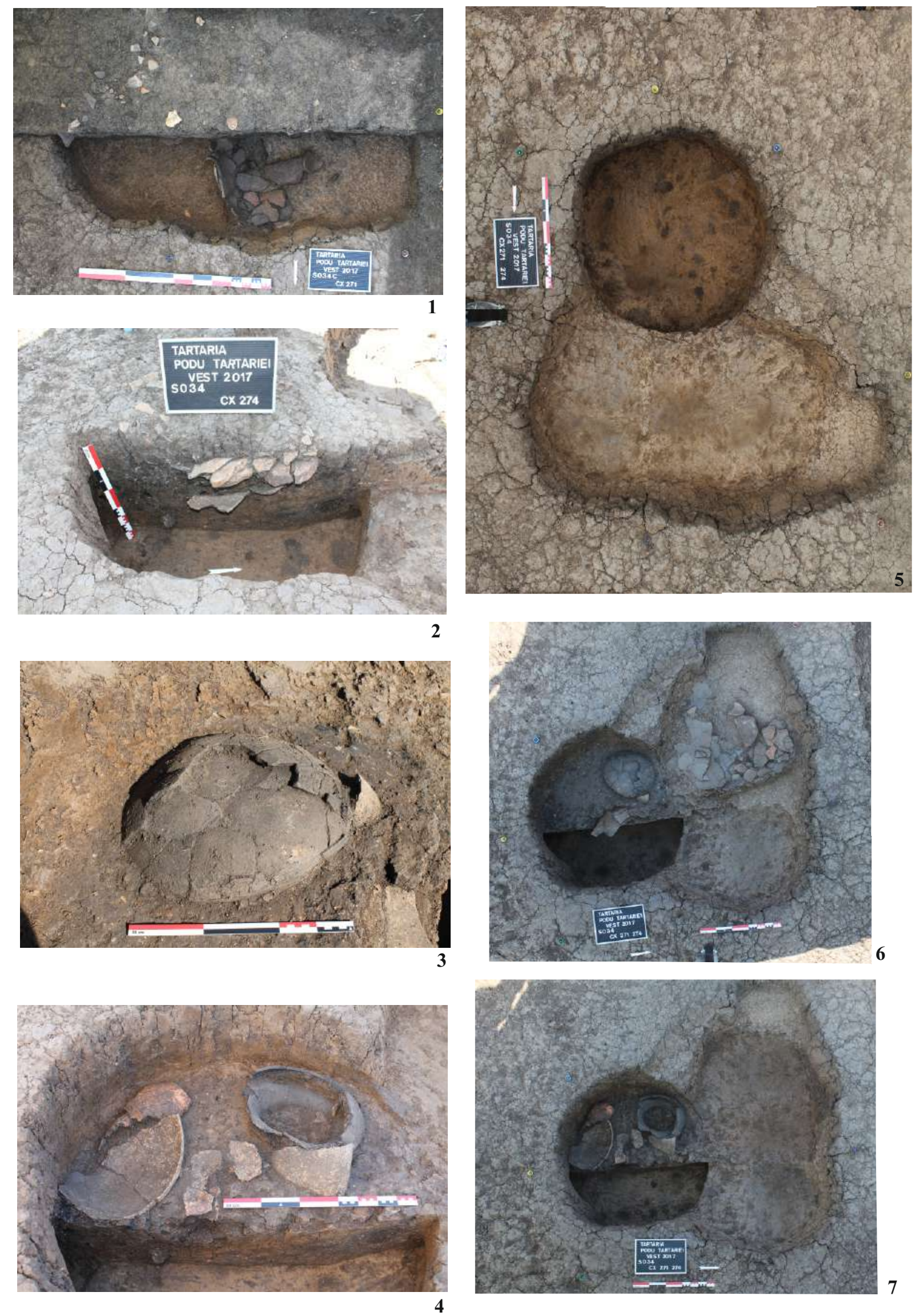

Cx. 271 şi Cx. 274: 1-7. Imagini din timpul cercetării complexelor 


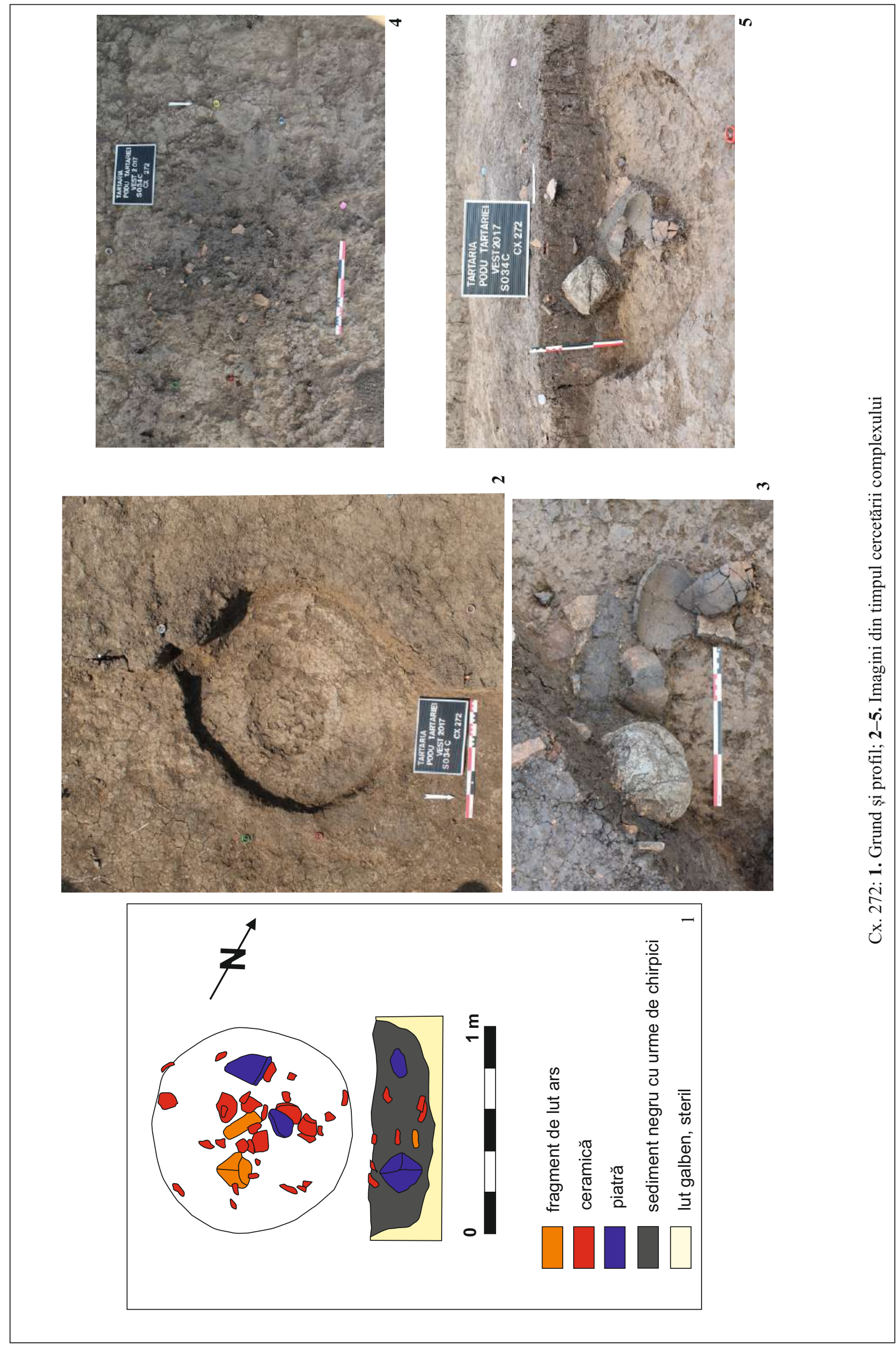



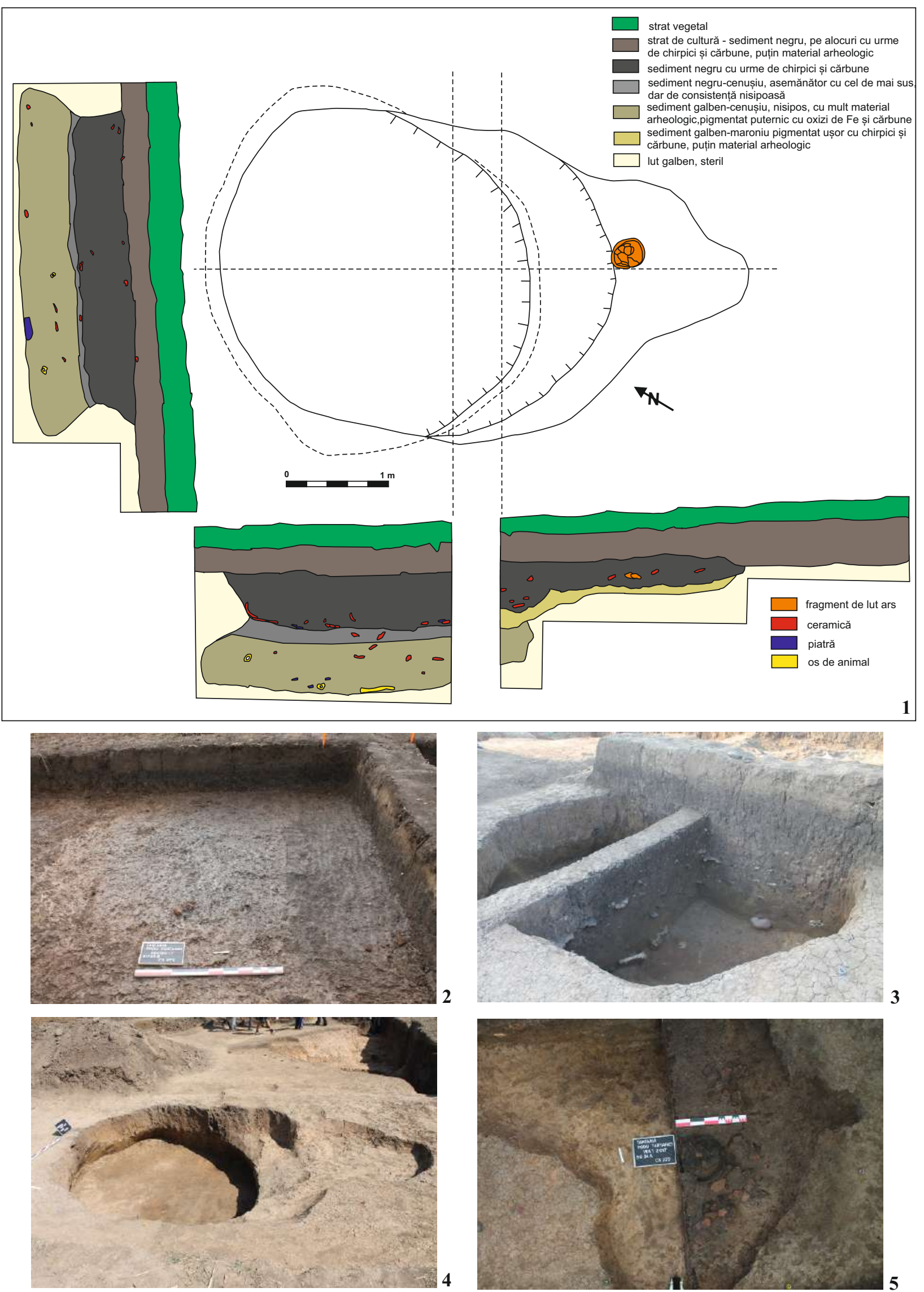

Cx. 273: 1. Grund și profil; 2-5. Imagini din timpul cercetării complexului; 

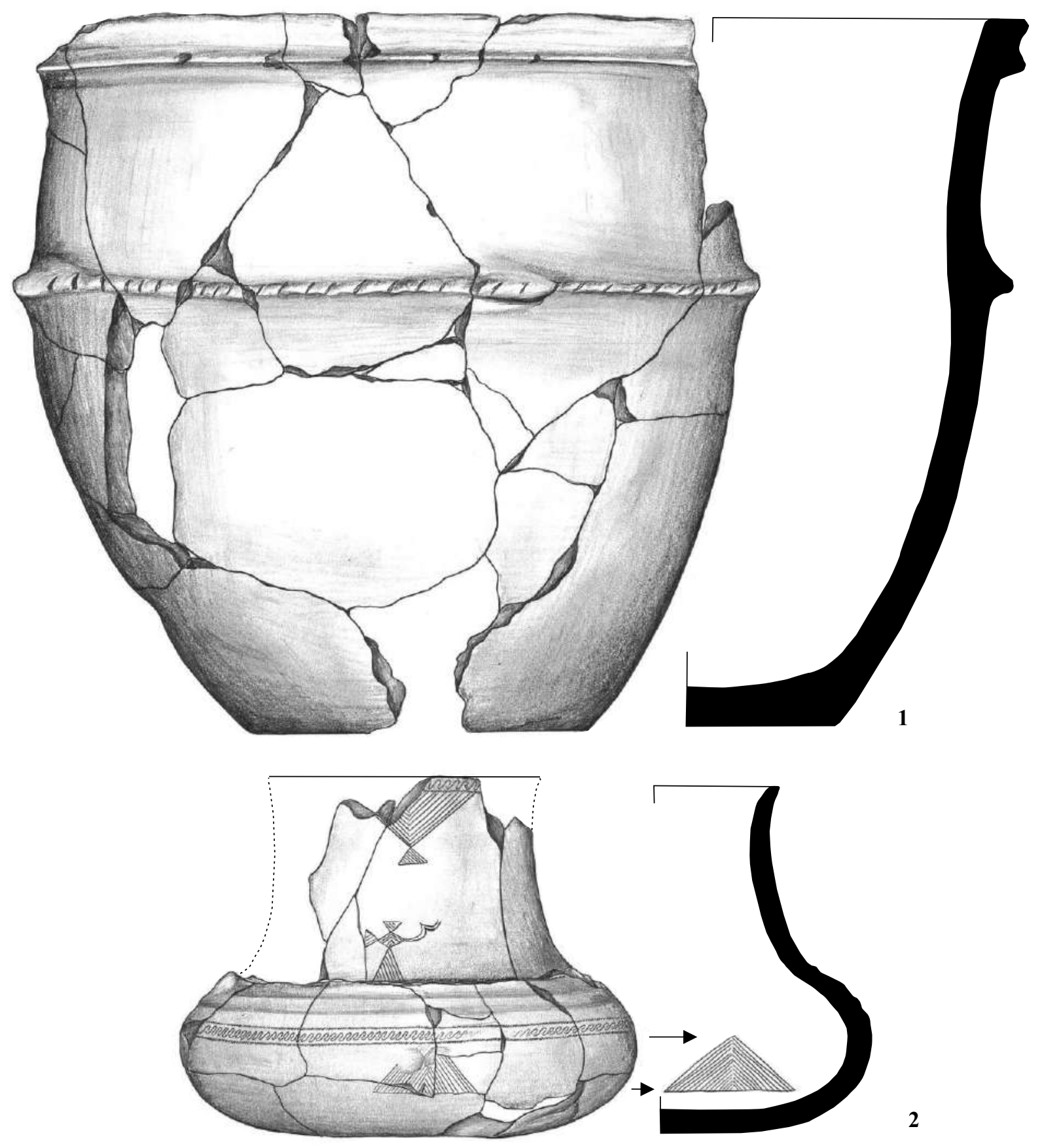

2
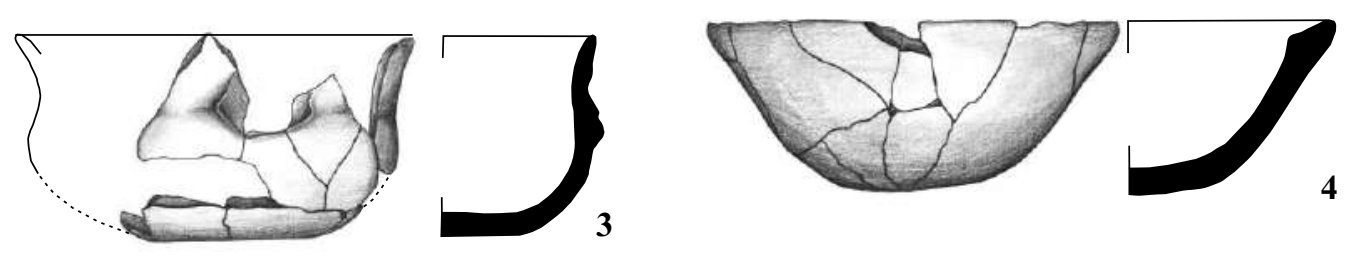

$0 \quad 2 \mathrm{~cm}$

Vase întregibile (selectiv): 1-2. Cx. 259; 3-4. Cx. 272

PI. XLII 


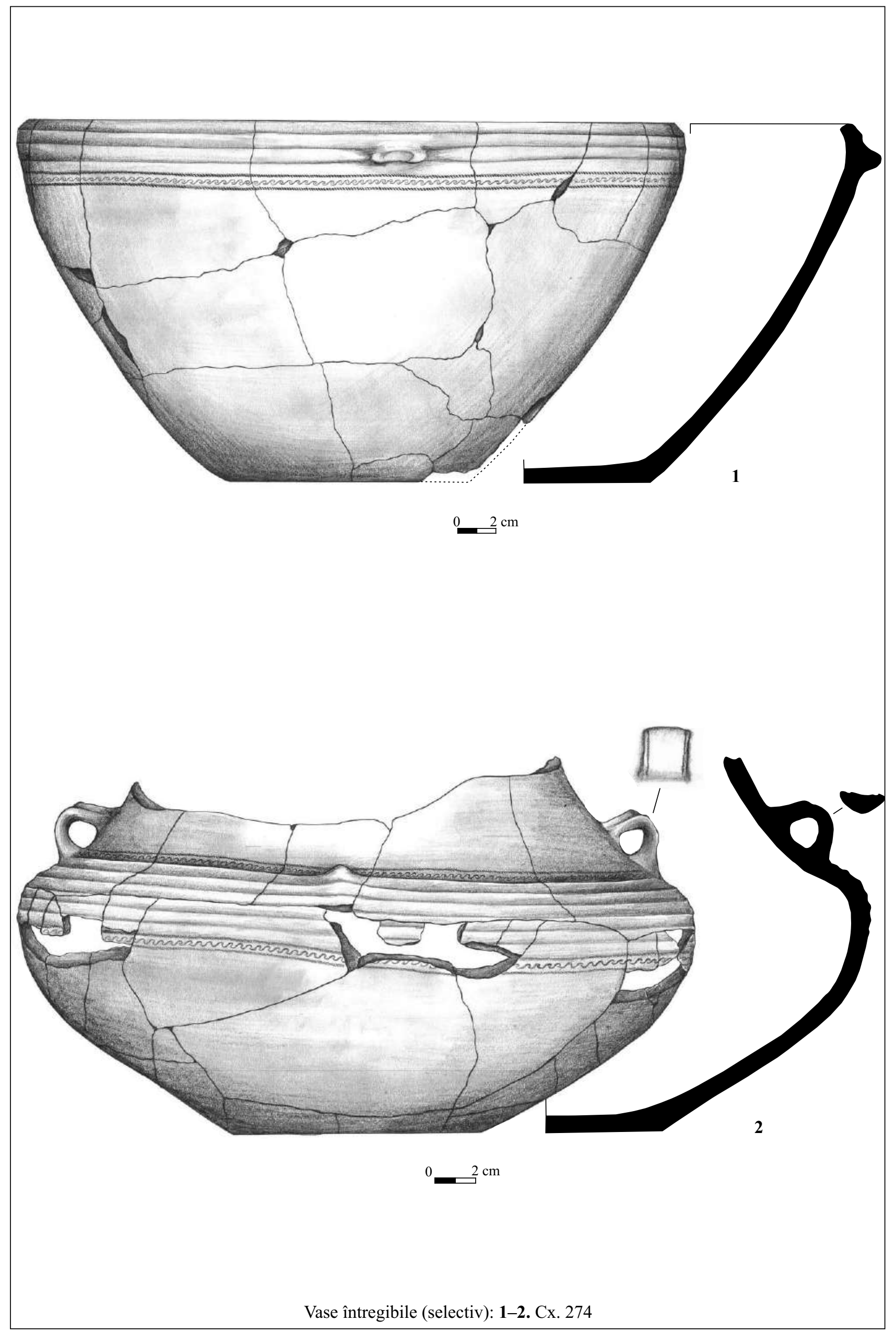

Pl. XLIII 


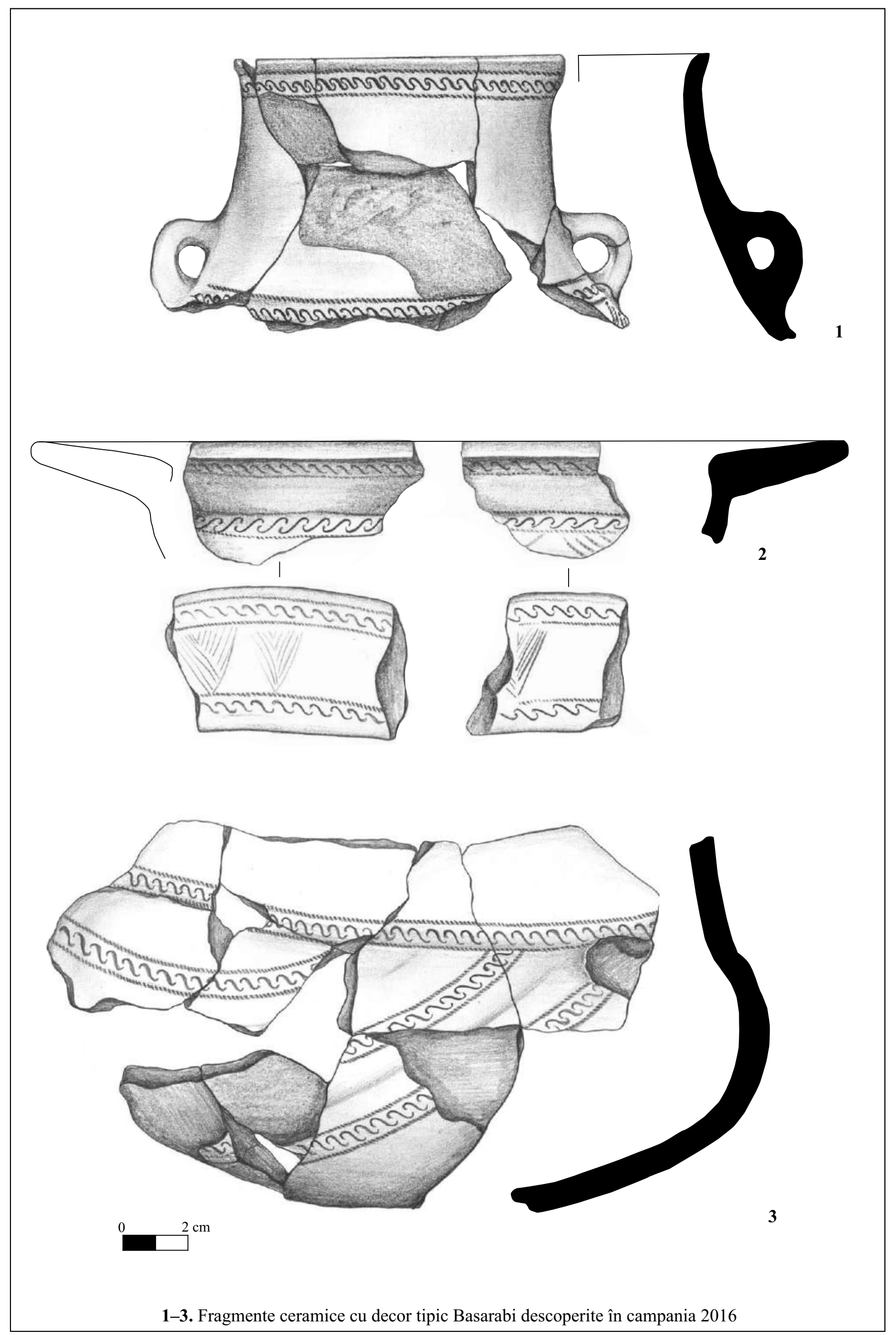

PI. XLIV 


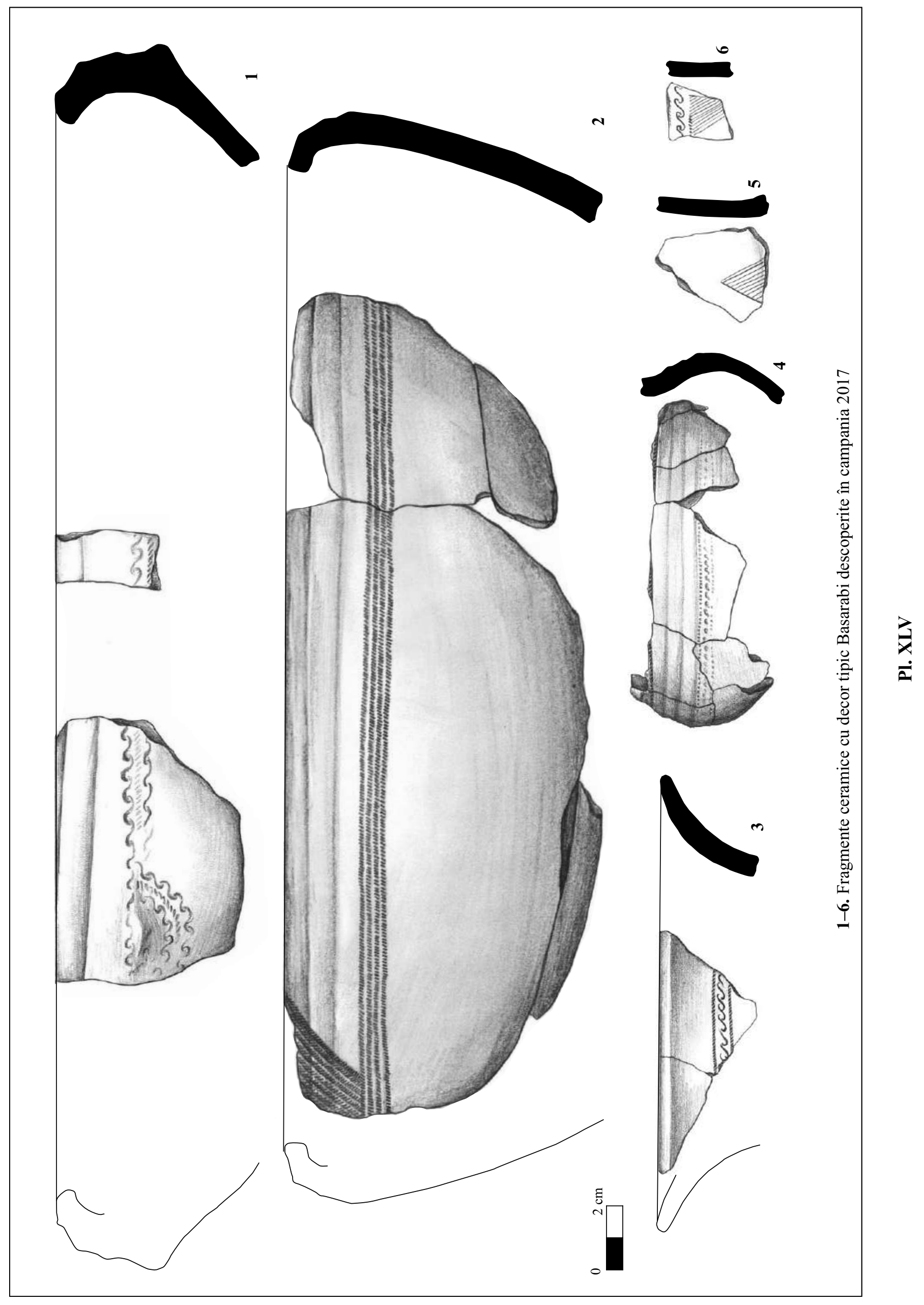




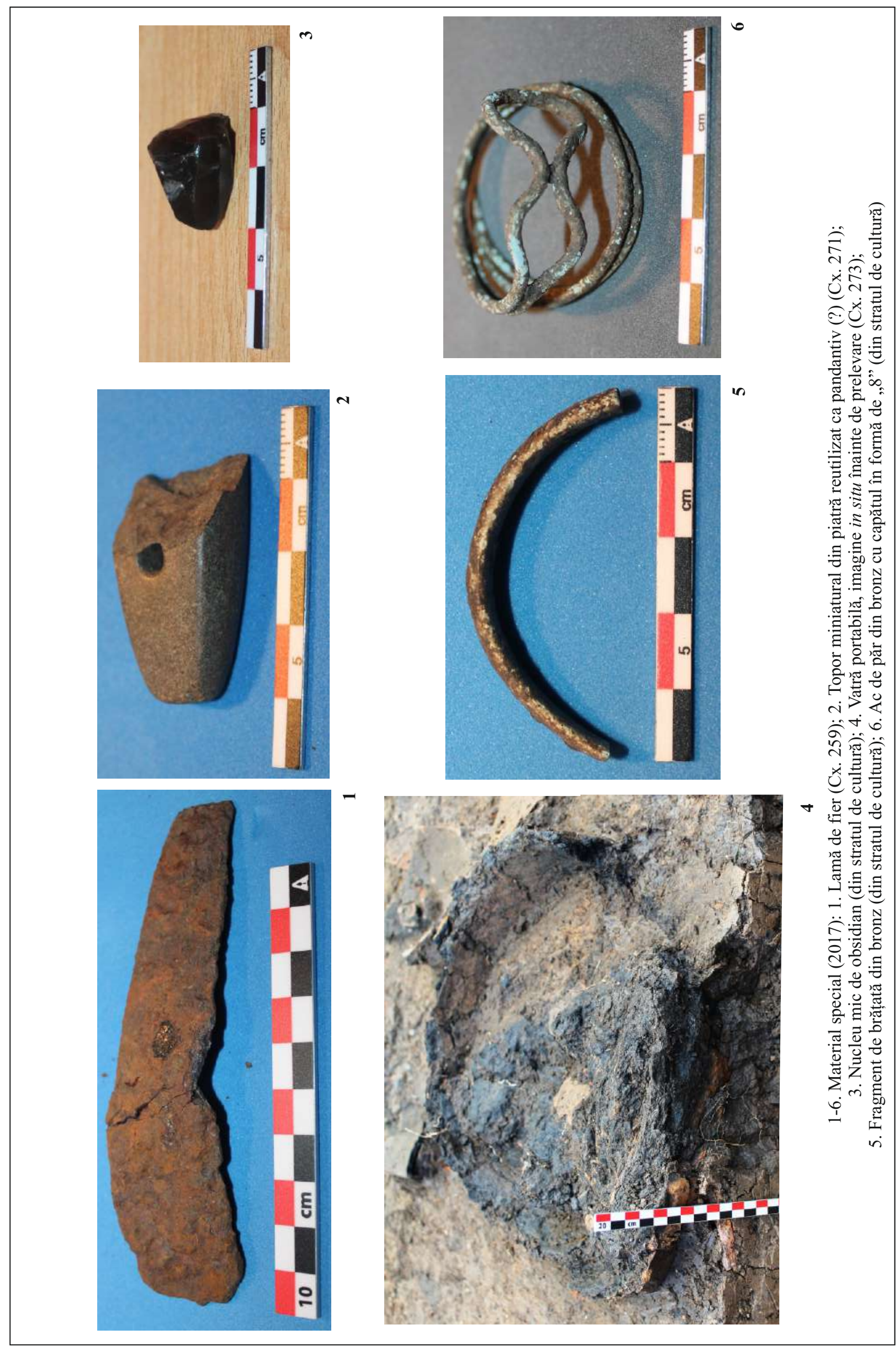




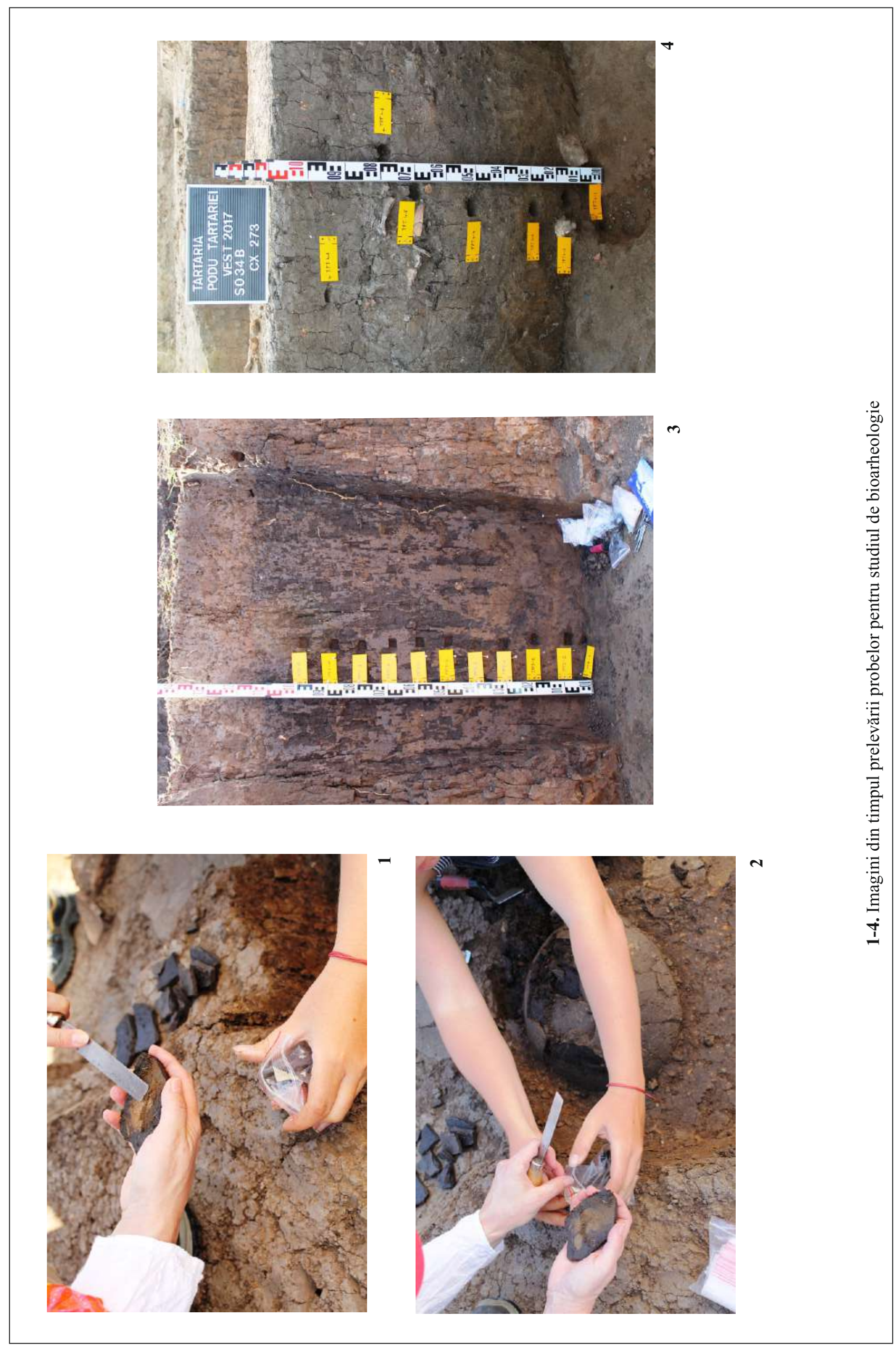




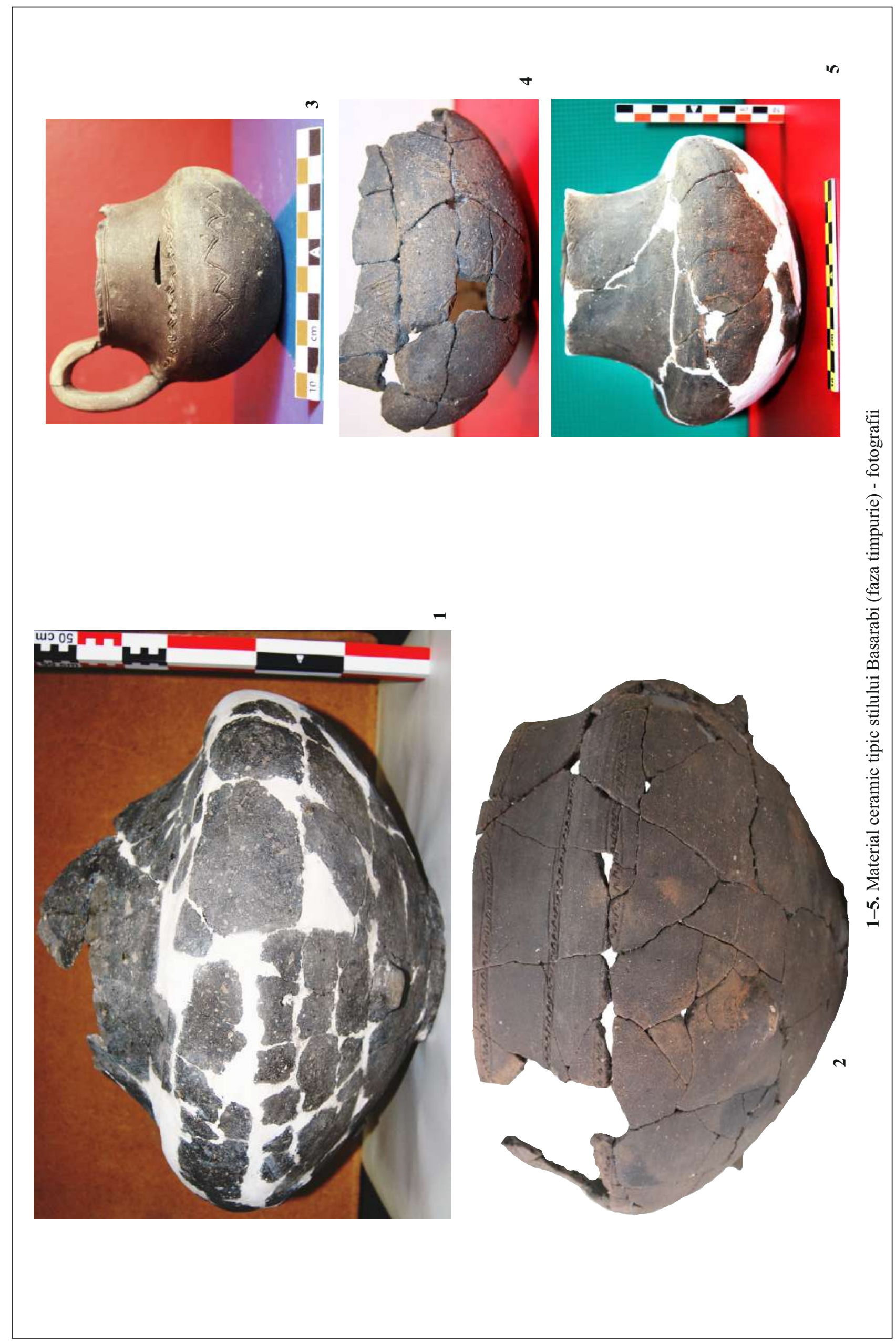




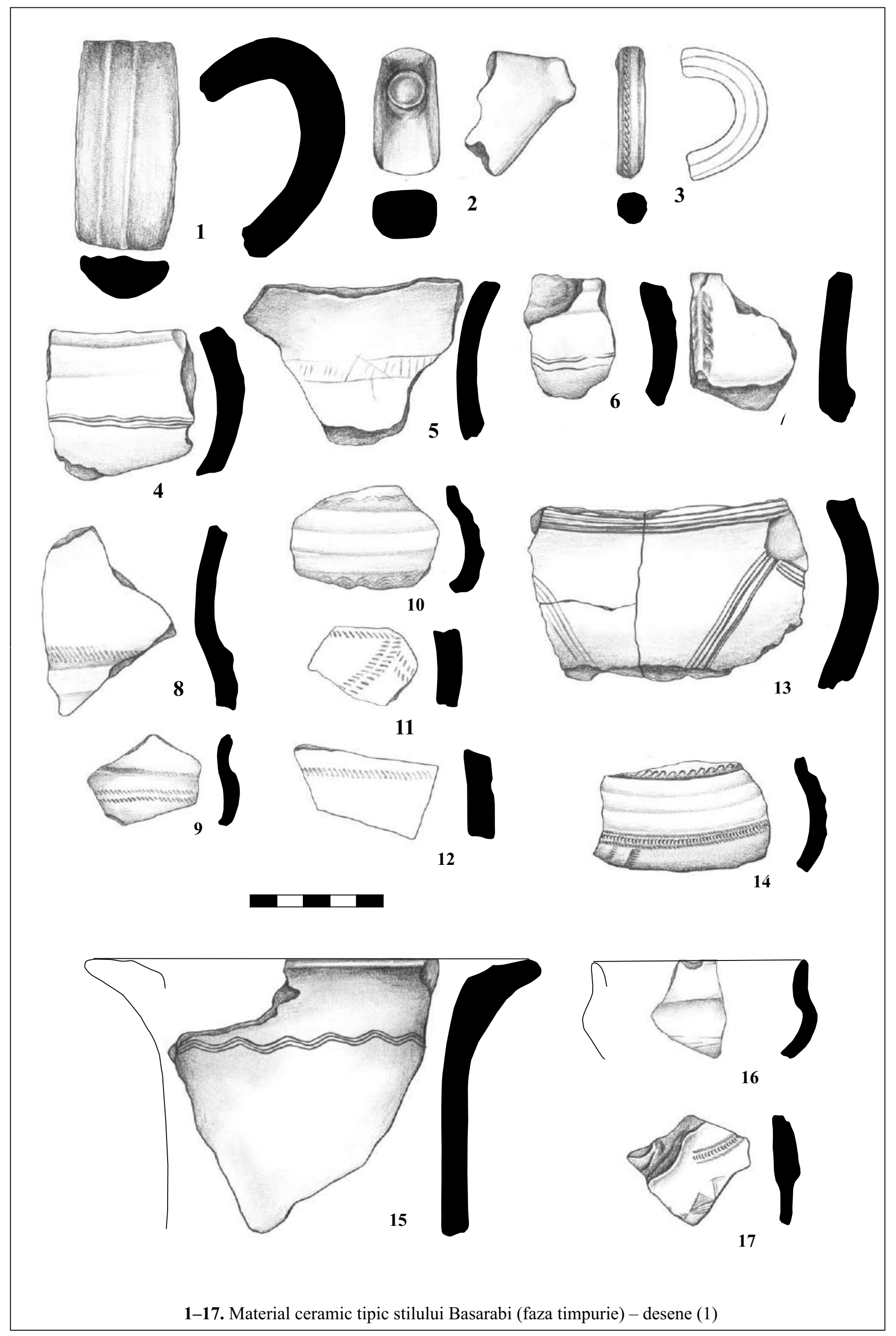

PI. XLIX 

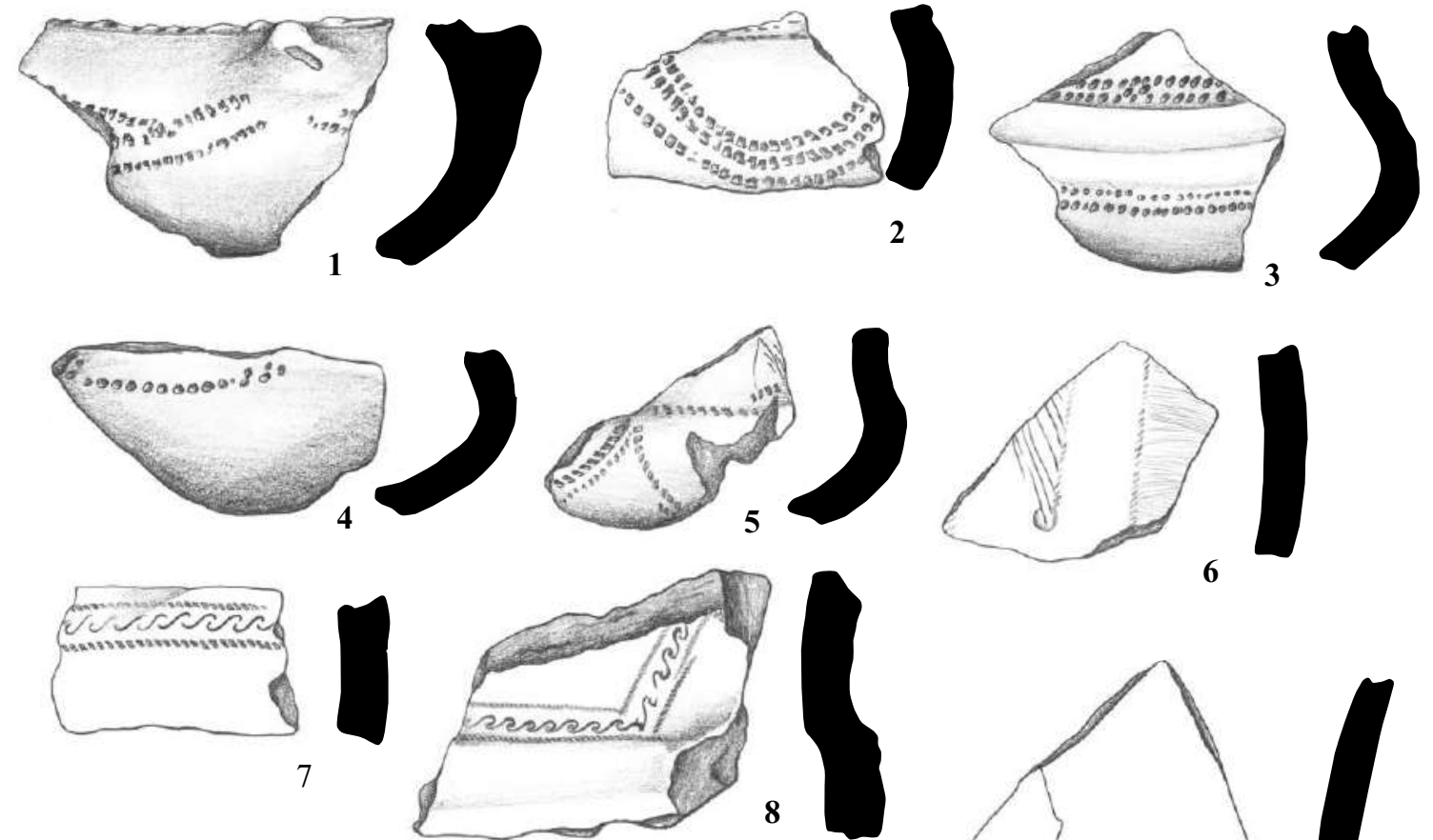

6
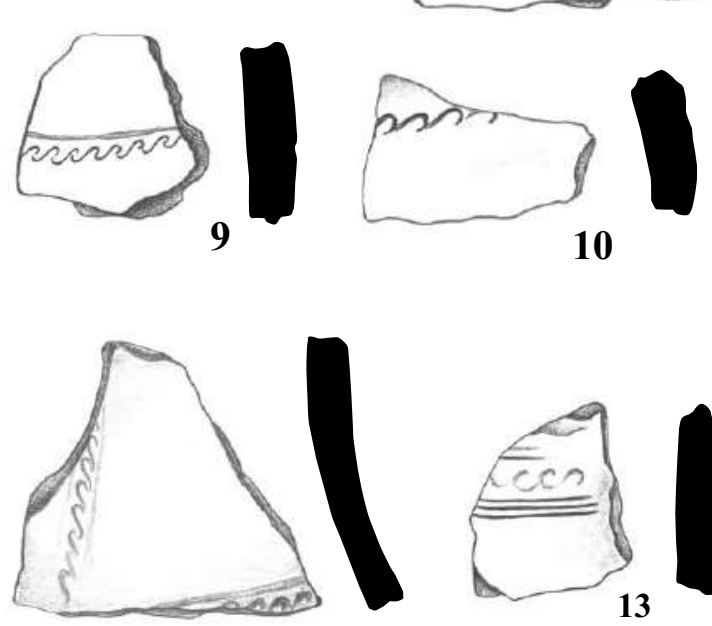

12
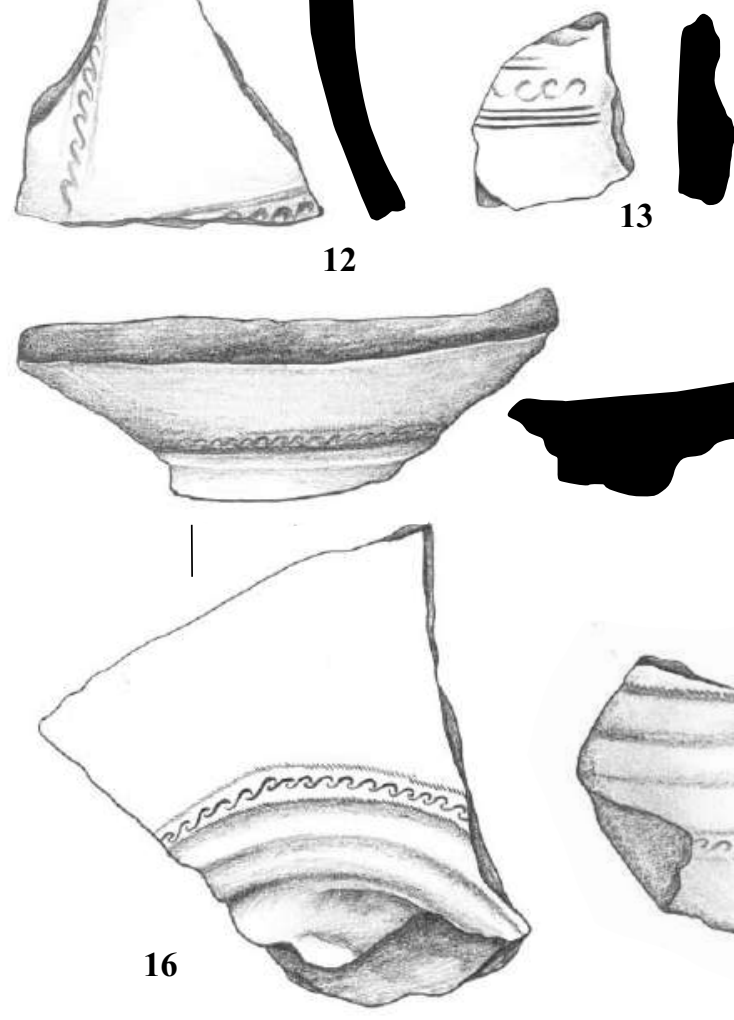

13

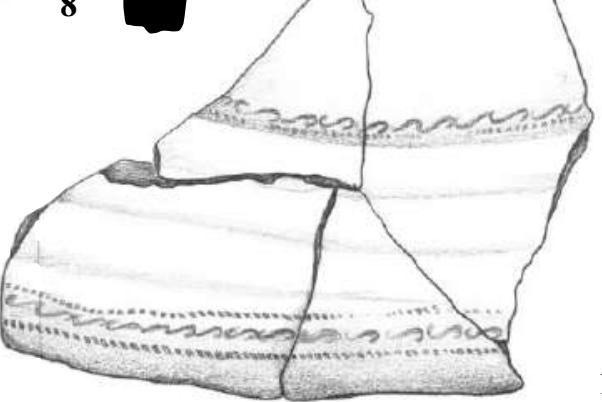

1
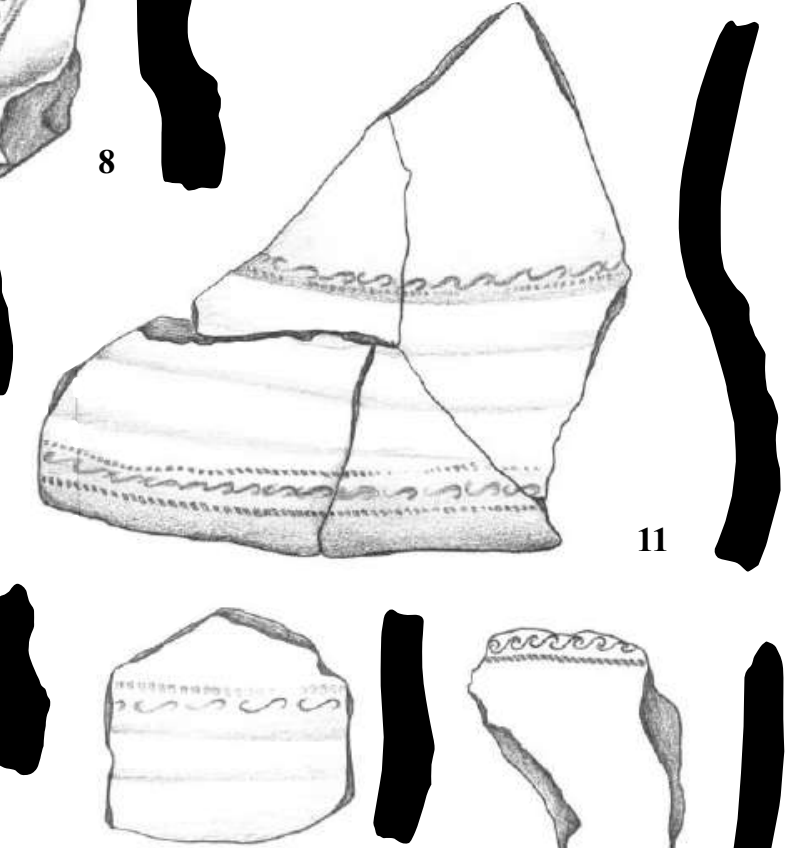

14

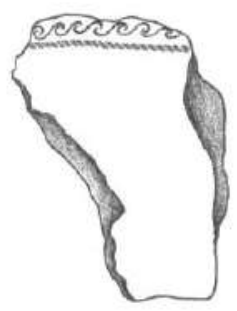

15
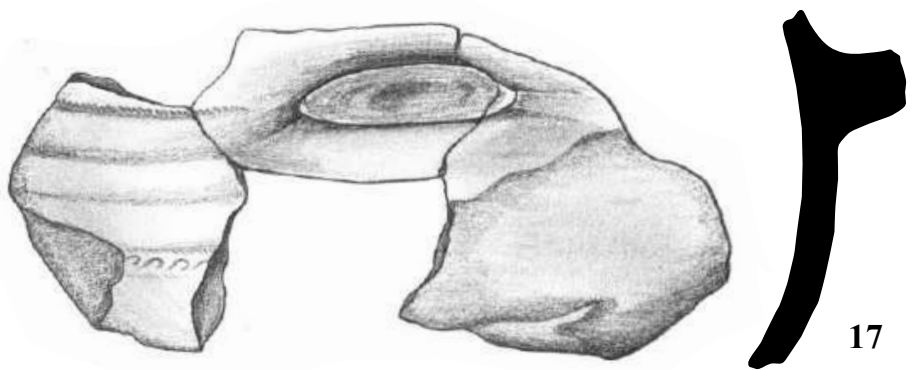

1-17. Material ceramic tipic stilului Basarabi (faza timpurie) - desene (2)

PI. L 